DOE/OR- -23701.3

DE91 015082

DOE/OR/23701.3

\title{
Engineering Evaluation/Cost Analysis \\ for the Proposed Removal of \\ Contaminated Materials at the \\ Elza Gate Site, Oak Ridge, Tennessee
}

June 1991

prepared by

Environmental Assessment and Information Sciences Division, Argonne National Laboratory, and Bechtel National, Inc.

\section{prepared for}

U.S. Department of Energy, Oak Ridge Operations Office, Formerly Utilized Sites Remedial Acton Program, under Contract W-31-109-Eng-38 


\section{DISCLAIMER}

This report was prepared as an account of work sponsored by an agency of the United States Government. Neither the United States Government nor any agency Thereof, nor any of their employees, makes any warranty, express or implied, or assumes any legal liability or responsibility for the accuracy, completeness, or usefulness of any information, apparatus, product, or process disclosed, or represents that its use would not infringe privately owned rights. Reference herein to any specific commercial product, process, or service by trade name, trademark, manufacturer, or otherwise does not necessarily constitute or imply its endorsement, recommendation, or favoring by the United States Government or any agency thereof. The views and opinions of authors expressed herein do not necessarily state or reflect those of the United States Government or any agency thereof. 


\section{DISCLAIMER}

Portions of this document may be illegible in electronic image products. Images are produced from the best available original document. 



\section{CONTENTS}

NOTATION $\ldots \ldots \ldots \ldots \ldots \ldots \ldots \ldots \ldots \ldots \ldots \ldots \ldots \ldots \ldots \ldots \ldots \ldots \ldots \ldots \ldots$

FOREWORD $\ldots \ldots \ldots \ldots \ldots \ldots \ldots \ldots \ldots \ldots \ldots \ldots \ldots \ldots \ldots \ldots \ldots \ldots$ viii

1 SITE CHARACTERIZATION $\ldots \ldots \ldots \ldots \ldots \ldots \ldots \ldots \ldots \ldots \ldots \ldots$

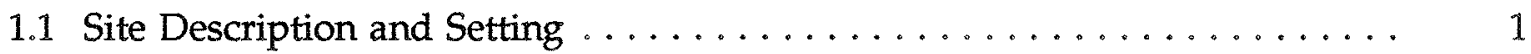

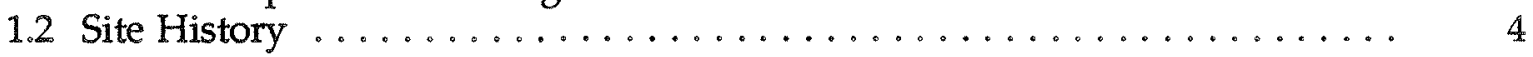

1.3 Summary of Previous Remedial Action Activities $\ldots \ldots \ldots \ldots \ldots \ldots$

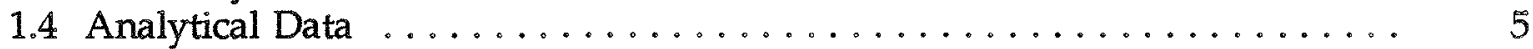

1.5 Site Conditions That Justify a Removal Action . . . . . . . . . . . . . . . 16

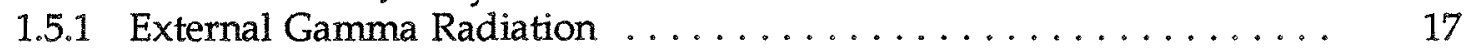

1.5.2 Residual Concentrations of Radionuclides in Soil . . . . . . . . . 17

1.5 .3 Radon Flux Levels . . . . . . . . . . . . . . . . . . . . 18

1.5 .4 Surface Contamination . . . . . . . . . . . . . . . . . 18

1.5.5 Chemical Contamination Levels . . . . . . . . . . . . . . 18

1.6 Potential Exposure Pathways . . . . . . . . . . . . . . . . . . . 19

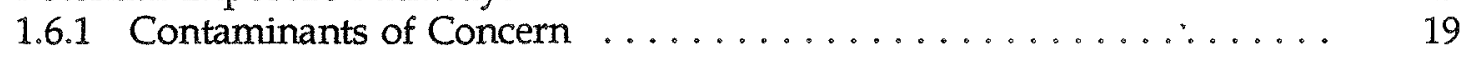

1.6.2 Release Mechanisms ........................ 20

1.6 .3 Environmental Fate . . . . . . . . . . . . . . . . . 20

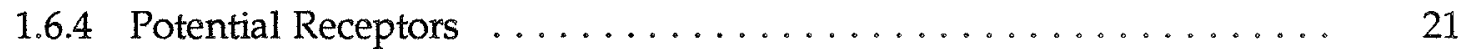

1.6 .5 Potential Risks . . . . . . . . . . . . . . . . . . . . . 21

2 REMOVAL ACTION OBJECTIVES . . . . . . . . . . . . . . . 22

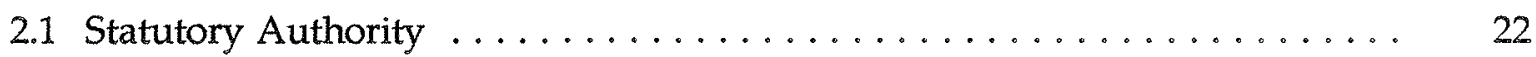

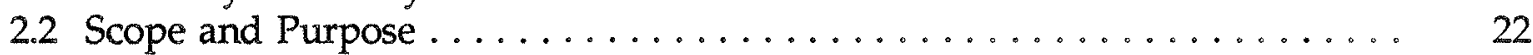

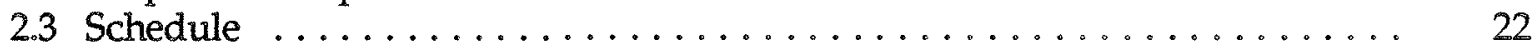

2.4 Compliance with Regulatory Requirements ................ 23

3 REMOVAL ACTION TECHNOLOGIES ................... 26

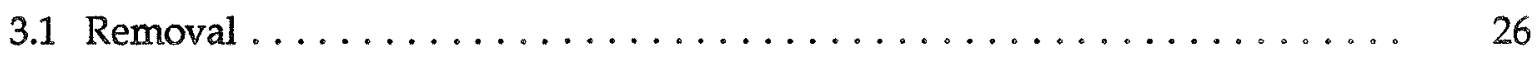

3.2 Access Restrictions . . . . . . . . . . . . . . . . . . . . . . 26

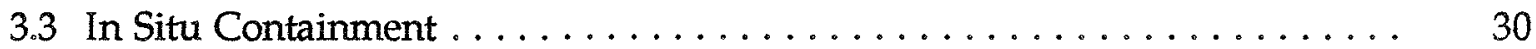

3.4 Reprocessing/Treatment . . . . . . . . . . . . . . . . . 30

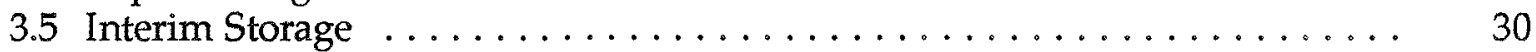

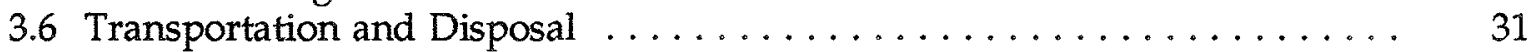

3.7. Identification of Preliminary Removal Action Alternatives . . . . . . . . . . 31

4 ANALYSIS OF ALTERNATIVES $\ldots \ldots \ldots \ldots \ldots \ldots \ldots \ldots \ldots \ldots$

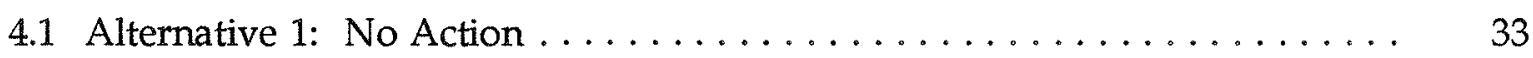

4.2 Alternative 2: On-Site Storage at the Elza Gate Site $\ldots \ldots \ldots \ldots \ldots \ldots . \ldots \ldots$

4.3 Alternative 3: Removal to the Oak Ridge Reservation ............... 34 


\section{CONTENTS (Cont'd)}

4.3.1 Protection of Public Health and the Environment $\ldots \ldots \ldots \ldots \ldots$

4.3 .2 Timeliness . . . . . . . . . . . . . . . . . . . . . . . 44

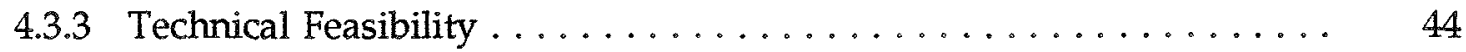

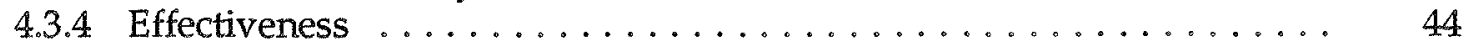

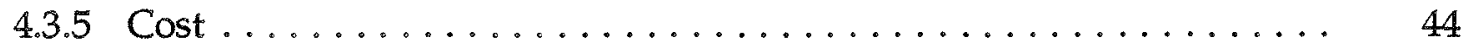

4.4 Identification of Proposed Alternative $\ldots \ldots \ldots \ldots \ldots \ldots \ldots \ldots$

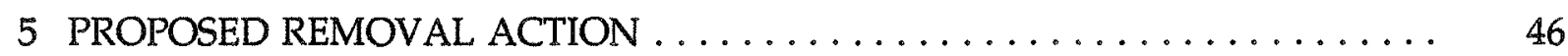

5.1 Description of Removal Action Activities . . . . . . . . . . . . . 46

5.2 Options at the Oak Ridge Reservation under the Preferred Alternative .... 47

5.2 .1 Waste Area Grouping $6 \ldots \ldots \ldots \ldots \ldots . \ldots \ldots$

5.2 .2 United Nuclear Corporation Chestnut Ridge Disposal Site . . . . . . 48

5.2 .3 East Central Chestnut Ridge Disposal Site . . . . . . . . . . . 48

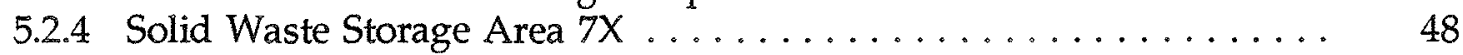

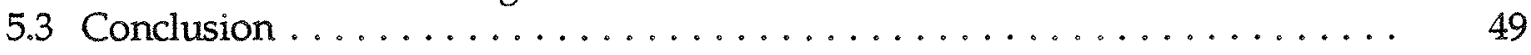

6 REFERENCES ................................. 50

7 LIST OF CONTRIBUTORS ....................... 53

APPENDIX: Determination of Applicability of ARAR and TBC

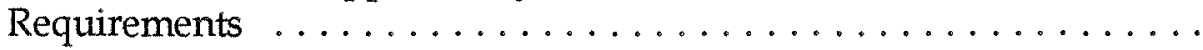

FIGURES

1 Location of the Elza Gate Site $\ldots \ldots \ldots \ldots \ldots \ldots \ldots \ldots \ldots \ldots \ldots \ldots \ldots$

2 Plan View of the Elza Gate Site $\ldots \ldots \ldots \ldots \ldots \ldots \ldots \ldots \ldots \ldots \ldots \ldots$

3 Soil-Sampling Locations for the 1989 Radiological Characterization of the Elza Gate Site . . . . . . . . . . . . . . . . . . . . . . . . . .

4 Areas of Radiological and PCB Contamination at the Elza Gate Site . . . . . . 9

5 Soil-Sampling Locations between the Elza Gate Site and the Melton Lake Reservoir . . . . . . . . . . . . . . . . . . . . . . 10

6 Approximate Locations of Chemical and Limited Radiological Sampling Points at the Elza Gate Site . . . . . . . . . . . . . . . . 12

$7 \quad$ Areas for Calculation of Doses with RESRAD Code . . . . . . . . . . . . . . 37 


\section{TABLES}

1 Summary of Radiological Data from the Elza Gate Site $\ldots \ldots \ldots . \ldots$

2 Radionuclide Concentrations in Soil between the Elza Gate Site and the Melon Lake Reservoir $\ldots \ldots \ldots \ldots \ldots \ldots \ldots \ldots \ldots \ldots \ldots$

3 Summary of Metal and PCB Concentrations in Soil at the Elza Gate Site .... 13

4 Direct Radiation Measurements on the Pads at the Elza Gate Site ........ 15

5 Federal Statutes, Executive Orders, and DOE Orders Potentially Pertinent to the Proposed Removal Action at the Elza Gate Site ......... 24

6 State Statutes Potentially Pertinent to the Proposed Removal

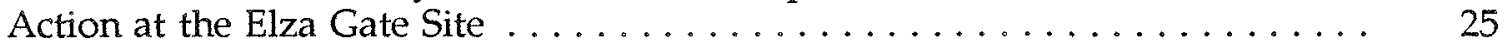

7 Summary of General Response Technology Screening $\ldots \ldots \ldots \ldots \ldots .27$

8 Input Variables for RESRAD Code Dose Calculations $\ldots \ldots \ldots \ldots \ldots \ldots . \ldots . \ldots$

9 Summary of Estimated External Exposure Doses by Area . . . . . . . . . 39

10 Summary of Estimated Inhalation Doses by Area $\ldots \ldots \ldots \ldots \ldots .40$

11 Summary of Estimated Total Doses by Area $\ldots \ldots \ldots \ldots \ldots \ldots . . \ldots 1$

12 Summary of Estimated Individual and Collective Doses by Area ...... 42

A.1 Potential Location-Specific Requirements . . . . . . . . . . . . . 58

A.2 Potential Contaminant-Specific Requirements $\ldots \ldots \ldots \ldots \ldots \ldots . \ldots 60 . \ldots$

A.3 Potential Action-Specific Requirements $\ldots \ldots \ldots \ldots \ldots \ldots \ldots . \ldots . \ldots$ 


\section{NOTATION}

The following is a list of the acronyms, initialisms, and abbreviations (including units of measure) used in this document.

\section{Acronyms, Initialisms, and Abbreviations}

$\begin{array}{ll}\text { AEC } & \text { U.S. Atomic Energy Commission } \\ \text { ARAR } & \begin{array}{l}\text { applicable or relevant and appropriate requirement } \\ \text { Comprehensive Environmental Response, Compensation, and Liability Act } \\ \text { of 1980, as amended } \\ \text { CERCLA }\end{array} \\ \text { CFR } & \text { U.S. Department of Energy } \\ \text { DOE } & \text { engineering evaluation/cost analysis } \\ \text { EE/CA } & \text { extraction procedure } \\ \text { EP } & \text { U.S. Environmental Protection Agency } \\ \text { EPA } & \text { extraction procedure toxicity } \\ \text { EP-toxicity } & \text { Formerly Utilized Sites Remedial Action Program } \\ \text { FUSRAP } & \text { low specific activity } \\ \text { LSA } & \text { Manhattan Engineer District } \\ \text { MED } & \text { mean sea level } \\ \text { MSL } & \text { National Oil and Hazardous Substances Pollution Contingency Plan } \\ \text { NCP } & \text { Oak Ridge Associated Universities } \\ \text { ORAU } & \text { Oak Ridge National Laboratory } \\ \text { ORNL } & \text { Oak Ridge Reservation } \\ \text { ORR } & \text { polychlorinated biphenyl } \\ \text { PCB } & \text { permissible exposure level } \\ \text { PEL } & \text { pressurized ionization chamber } \\ \text { PIC } & \text { Resource Conservation and Recovery Act } \\ \text { RCRA } & \text { Superfund Amendments and Reauthorization Act of 1986 } \\ \text { SARA } & \text { solid waste storage area } \\ \text { SWSA } & \text { (requirements) to be considered } \\ \text { TBC } & \text { toxicity characteristic leaching procedure } \\ \text { TCLP } & \text { Toxic Substances Control Act } \\ \text { TSCA } & \text { waste area grouping } \\ \text { WAG } & \end{array}$

\section{Units of Measure}

$\begin{array}{ll}\mathrm{cm} & \text { centimeter(s) } \\ \mathrm{cm}^{2} & \text { square centimeter(s) } \\ \mathrm{dpm} & \text { disintegrations per minute } \\ \mathrm{ft} & \text { foot (feet) } \\ \mathrm{ft}^{2} & \text { square foot (feet) } \\ \mathrm{g} & \text { gram(s) } \\ \mathrm{gal} & \text { gallon(s) } \\ \mathrm{h} & \text { hour(s) }\end{array}$




$\begin{array}{ll}\text { ha } & \text { hectare(s) } \\ \mathrm{in} & \text { inch(es) } \\ \mathrm{kg} & \text { kilogram(s) } \\ \mathrm{km} & \text { kilometer(s) } \\ \mathrm{m} & \text { meter(s) } \\ \mathrm{m}^{2} & \text { square meter(s) } \\ \mathrm{m}^{3} & \text { cubic meter(s) } \\ \mu \mathrm{R} & \text { microroentgen(s) } \\ \mathrm{mi} & \text { mile(s) } \\ \mathrm{mrem} & \text { millirem(s) } \\ \mathrm{min} & \text { minute(s) } \\ \mathrm{pCi} & \text { picocurie(s) } \\ \mathrm{ppb} & \text { part(s) per billion } \\ \mathrm{ppm} & \text { part(s) per million } \\ \mathrm{s} & \text { second(s) } \\ \mathrm{yd} & \text { cubic yard(s) } \\ \mathrm{yr} & \text { year(s) }\end{array}$




\section{FOREWORD}

This engineering evaluation/cost analysis (EE/CA) has been prepared in support of the proposed removal action for cleanup of radioactive and chemically contaminated soil at the Elza Gate site in Oak Ridge, Tennessee. This property became contaminated as a result of storage of ore residues, equipment, and other materials for the U.S. Atomic Energy Commission. The U.S. Department of Energy is responsible for cleanup of portions of the site under its Formerly Utilized Sites Remedial Action Program. In December 1990 an area known as Pad 1 was abrasively scoured to remove surface contamination, and in March 1991 removal of Pad 1 contamination was begun under a separate EE/CA. This EE/CA is intended to cover the remaining portions of the site for which the Department of Energy has responsibility.

It has been determined that an EE/CA report is the appropriate documentation for the proposed removal action. This EE/CA covers removal of contaminated soils and contaminated concrete rubble from the Elza Gate site. The primary objectives of this EE/CA report are to identify and describe the preferred removal action, and to document the selection of response activities that will mitigate the potential for release of contaminants from the property into the environment and that will minimize the associated threats to human health or welfare and the environment. The preferred alternative is disposition on the Oak Ridge Reservation. 


\section{SITE CHARACTERIZATION}

\subsection{SITE DESCRIPTION AND SETTING}

The Elza Gate site (Fig. 1) is rectangular, running along a northeast to southwest line, and covers an area of about 7 hectares (ha) (17 acres). It is located in the southeastern part of the city of Oak Ridge, Tennessee, near the intersection of Melton Lake Drive and Oak Ridge Turnpike. The site became contaminated with radioactive materials when the Manhattan Engineer District (MED), during the early 1940s, and subsequently the U.S. Atomic Energy Commission (AEC) used it to store uranium ore, ore processing residues, equipment, and perhaps other materials. Polychlorinated biphenyls (PCBs) found on the site resulted from the storage of electrical equipment by U.S. Department of Energy (DOE) predecessor agencies. The Elza Gate site, also known as the Melton Lake Industrial Park, is owned by MECO, a real-estate development company; the site is being developed for use as an industrial park and presently has one tenant, Electro-Panel, a company that manufactures containers for low-level radioactive waste.

The Oak Ridge region is characterized by a ridge and valley topography, with a series of northeast-southwest trending ridges and intervening valleys. The ridges are breached at irregular intervals by stream channels, which otherwise follow the trend of the valleys. The ridges in the area reach elevations of approximately 300 meters (m) or 1000 feet ( $\mathrm{ft}$ ), above mean sea level (MSL). The elevation of the Elza Gate site drops from $258 \mathrm{~m}(846 \mathrm{ft}) \mathrm{MSL}$ on the northwest side to $244 \mathrm{~m}(800 \mathrm{ft}) \mathrm{MSL}$ on the southeast side and is about $150 \mathrm{~m}(500 \mathrm{ft})$ from the southwest shore of Melton Hill Lake (see Fig. 1). The soils in the site area are sandy loams. The Clinch River, which eventually discharges into the Tennessee River, is the source of most of the water used in the Oak Ridge area. Melton Hill Lake is a backwater of the Clinch River and lies along Melton Lake Drive, with the Melton Lake Reservoir extending along the southeast side of

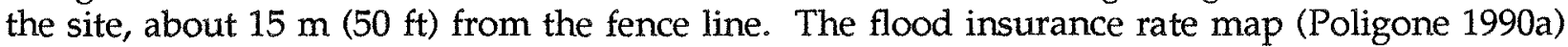
indicates that the site lies outside the 100-year floodplain, and all but a small area lies outside the 500-year floodplain. However, dams along the Clinch River control river levels so that levels in the reservoir fluctuate accordingly.

The climate at Oak Ridge is warm and humid. The summers are dominated by warm, moist air from the Gulf of Mexico. In the winter, cold, dry air masses from Canada are warmed as the air crosses the Cumberland Mountains and moves down the eastern slopes to the Oak Ridge area. Precipitation averages 140 centimeters $(\mathrm{cm})(55$ inches [in.]) annually; the relative humidity averages $70 \%$ (Liedle 1990a). The maximum 24 -hour (h) rainfall is about $20 \mathrm{~cm}(8 \mathrm{in}$.) Approximately $70 \%$ of the average annual precipitation is lost through evapotranspiration, and the rest becomes runoff to surface waters and recharge to the groundwater. Snow is infrequent, but sometimes occurs in sufficient quantity to hinder traffic and outdoor activities.

Winds on the ridges blow predominantly from the southwest, although northeast winds are also frequent. Remnants of hurricanes and tropical storms occasionally affect the area.

\footnotetext{
"In referring to specific parts of the Elza Gate site, see Fig. 2 where, moving clockwise around the site, the entrance road off Melton Lake Drive constitutes the northeast corner, the fence line along the Melton Lake Reservoir constitutes the southeast side, the fence line near Pad 5 the southwest side, and the remaining fence line the northwest side.
} 


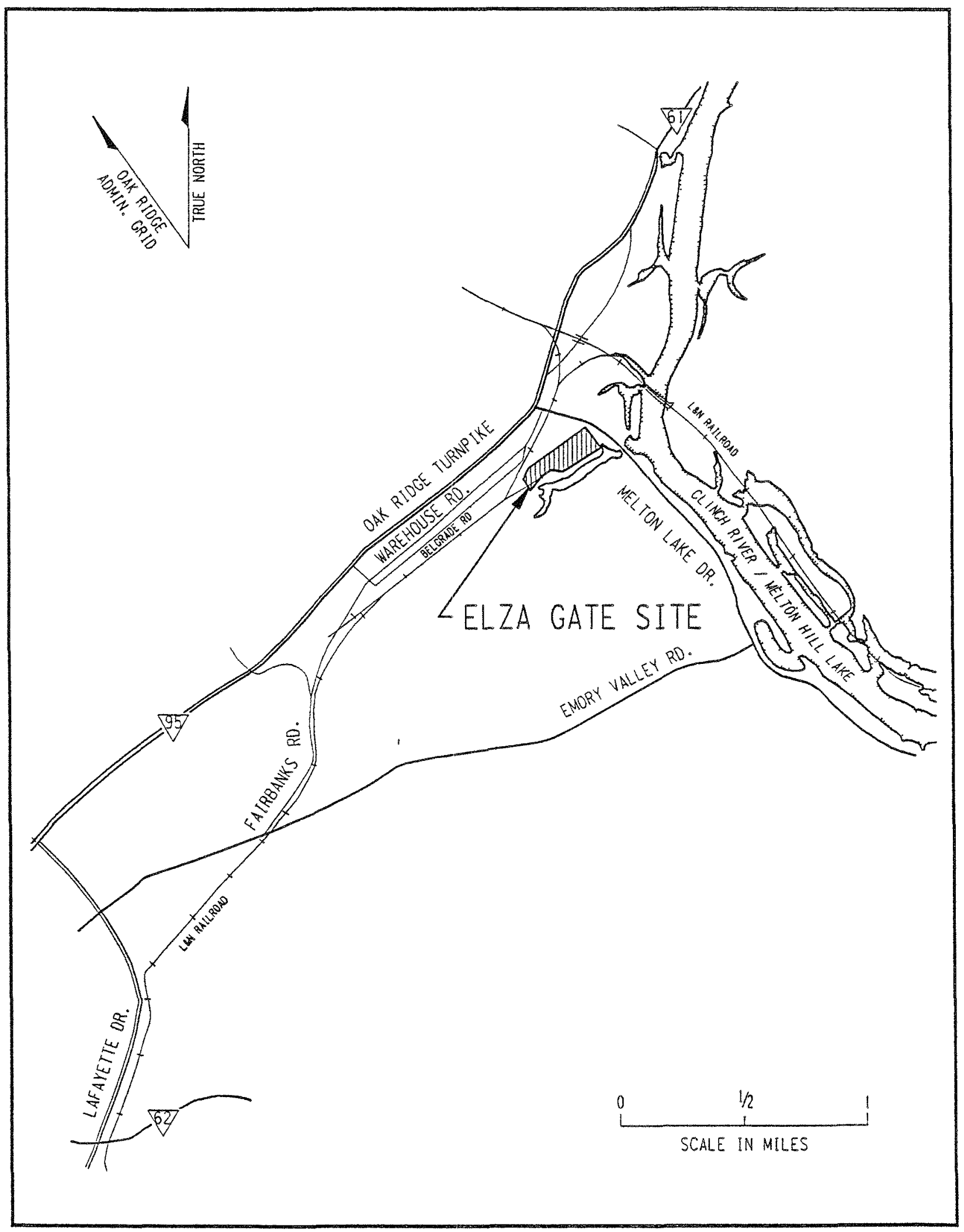

FIGURE 1 Location of the Elza Gate Site 


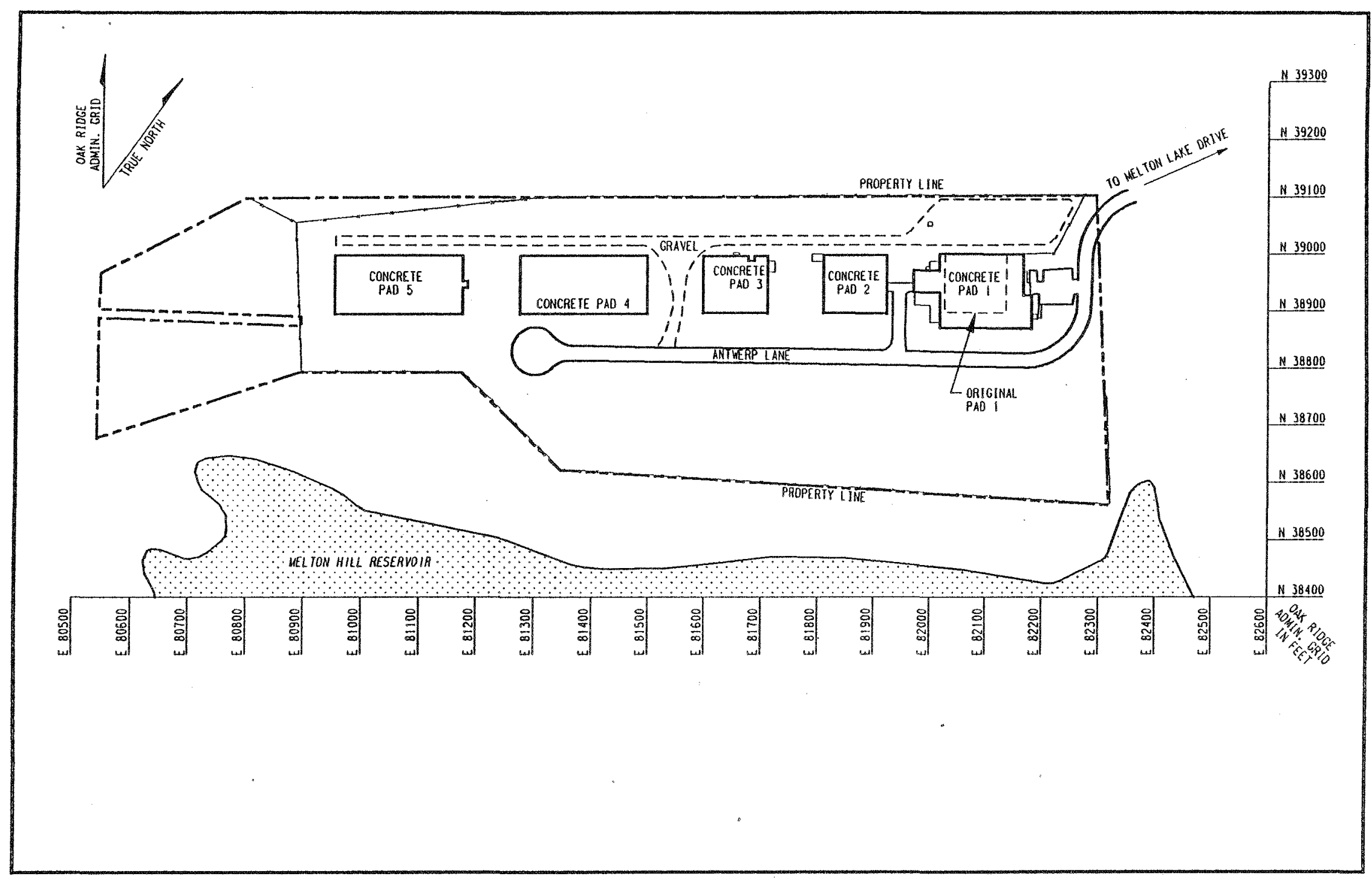




\subsection{SITE HISTORY}

During the 1940s, the MED used the Elza Gate site to store pitchblende (a high-grade uranium ore from Africa), residue from ore processing, and other radioactive materials. Originally, five warehouses were on the site; at least three of them were used for storage of radioactive materials. One warehouse was used principally for storage of uranium slag, which was intended for reprocessing. Another held pitchblende, uranium oxide residues, and tailings. A third warehouse held low-grade ore, which was initially stored in burlap bags. The ore was rebagged on-site. In 1946, ownership of the site passed to the AEC, which used the warehouses for storage of equipment from the $\mathrm{Y}-12$ gaseous diffusion plant and possibly from other areas until they were vacated in 1972. During the MED/AEC era, the complex was accessed by a railroad spur to the southeast and by a road that entered from what is now Melton Lake Drive. The railroad spur has since been removed and has been replaced by an access road between the site and Melton Lake Drive.

After a radiological survey and decontamination by Oak Ridge National Laboratory (ORNL) in 1972, it was recommended that the site be released for use without radiological restrictions (Sapirie 1972). The property was then relinquished by the AEC in 1972, and title to the property was assumed by the city of Oak Ridge. That same year, the city sold the property to Jet Air, Inc., which operated a fabricating and metal plating facility on the site. Jet Air, in turn, sold the property to MECO in 1988. The concrete pads from MED warehouses remain; the original warehouse buildings have been removed (Fig. 2).

In 1987, at the request of the Tennessee Department of Health and Environment, a survey by Oak Ridge Associated Universities (ORAU) (Egli 1988) was conducted at the site because of the possibility of contamination from the Jet Air metal plating facility. The survey confirmed the presence of heavy metal contamination. In addition, uranium was discovered in concentrations above background levels in the soil in some areas.

In 1988, MECO added offices to the structure on Pad 1 built by Jet Air and constructed a new access road along the southeast side of the concrete pads for the purpose of developing the property for lease and sale as an industrial park. In October and November 1988, the pad area along Antwerp Lane was radiologically surveyed by the Measurement Applications and Development Group of ORNL (Cottrell et al. 1989). This area and the original site access road were found to exceed DOE's radiological criteria for unrestricted use of a site, making the site eligible for inclusion in the Formerly Utilized Sites Remedial Action Program (FUSRAP). On November 30, 1988, the entire Melton Lake Industrial Park was authorized for inclusion in FUSRAP (Fiore 1988).

The only on-site structure is currently occupied by a company that manufactures storage containers for low-level radioactive waste. Since DOE does not own the site, modification of the property might occur as it is leased or sold.

\subsection{SUMMARY OF PREVIOUS REMEDIAL ACTION ACTIVITIES}

A preliminary radiological survey and a limited chemical characterization of the Elza Gate site were conducted in 1989 (Bechtel National 1989a) to support preliminary assessment of health risks and the development of remedial alternatives. The scope of the survey was limited 
to surface and near-surface investigative techniques. The site was further characterized in 1990 (Bechtel National 1991).

In addition to the site characterization described above, a decontamination technology was demonstrated at the Elza Gate site in the summer of 1989 (Argonne National Laboratory 1989). A portable blast cleaning system, normally used to prepare concrete surfaces for application of coatings, was tested to determine its effectiveness in removing contamination from poured concrete horizontal surfaces. The technique was demonstrated on approximately $1100 \mathrm{~m}^{2}$ $\left(12,000 \mathrm{ft}^{2}\right)$ of the original Pad 1 and was effective in reducing the surface contamination levels on the pad. However, rough, uneven surfaces resulted because of various contamination depths in the concrete and the density of an aggregate fill material that was somewhat impervious to abrasive blasting. The concrete needed resurfacing to restore it to its original condition after the blasting. Expansion joints and cracks were not effectively decontaminated; these were determined to require further remedial efforts. The cleaning system generated approximately $11.5 \mathrm{~m}^{3}\left(15 \mathrm{yd}^{3}\right)$ of dust contaminated with uranium and its decay products. The contaminated dust was placed in low specific activity (LSA) boxes and transported to the Oak Ridge Reservation (ORR) of the DOE for storage. In general, as a result of the work, both direct alpha and beta-gamma activity readings across the pad surface were reduced. The average betagamma readings decreased from 15,000 disintegrations per minute $(\mathrm{dpm})$ per $100 \mathrm{~cm}^{2}$ to less than the surface contamination cleanup guideline of $5,000 \mathrm{dpm}$ per $100 \mathrm{~cm}^{2}$ (Devgun et al. 1990).

The property owner needed to remove the cracked, worn concrete from Pad 1 and replace it with new concrete that would provide a more solid footing for equipment and safer flooring for workers. An engineering evaluation/cost analysis (EE/CA) for the removal of contaminated materials from Pad 1 was prepared in September 1990 (U.S. DOE 1990a). Removal action began in March 1991. Thus, the removal of radioactively contaminated concrete from Pad 1 and the radioactively contaminated soil beneath the pad has been addressed as a separate removal action. Wastes generated from this removal action are in interim storage on a synthetic membrane liner on Pad 4 and are covered. Permanent waste disposal or waste removal to an off-site location was not addressed in the $1990 \mathrm{EE} / \mathrm{CA}$, however, and is included in this documentation, which is aimed at overall site remediation.

\subsection{ANALYTICAL DATA}

A preliminary radiological survey of the Elza Gate site was conducted by ORNL (Cottrell et al. 1989). The survey included measurements of gamma exposure rates at $1 \mathrm{~m}$ ( $3 \mathrm{ft}$ ) above the surface, determination of direct and transferable alpha and beta-gamma activity levels on surfaces inside the building and in selected locations on outdoor concrete surfaces, a gamma scan at the surface inside the building and throughout parcels 1 through 4 , and collection and analysis of soil samples. Surface water and groundwater data were not taken. The survey results showed that widespread residual radioactivity from former operations remained on the property, primarily in outdoor soil and as surface contamination on three concrete pads. The radionuclides identified were uranium-238, thorium-230, and radium-226. The survey also identified cesium-137 above 1 picocurie per gram ( $\mathrm{pCi} / \mathrm{g}$ ) at four points (the peak being $9.9 \mathrm{pCi} / \mathrm{g}$ ). Subsequent measurements have detected neither this contaminant nor any others not found in the three natural decay series (uranium, thorium, actinium).

An expanded radiological, chemical, and hydrogeological characterization of the Elza Gate site was subsequently performed in two phases by Bechtel National, Inc., to obtain 
adequate data for developing a protective and cost-effective remedial action alternative for the site (Bechtel National 1991). Phase 1 in 1989 focused on radiological surveillance, while Phase 2 in 1990 focused on chemical surveillance with some additional radiological sampling. There was a limited supplemental sampling in the area between the southeast fence and the Melton Lake Reservoir in October 1990 (Bechtel National 1991). The goals in Phases 1 and 2 of the characterization were to identify the location and extent of the contamination, define the characteristics of the waste, investigate potential waste migration pathways, determine whether the waste exhibits hazardous characteristics as defined by the Resource Conservation and Recovery Act (RCRA), and assess the potential health hazards to workers performing remedial action. The goals of the supplemental sampling were to determine whether radioactive or PCB contamination was present outside the fence along the bank of the Melton Lake Reservoir.

Radiological characterization techniques included near-surface "walk over" gamma scanning, soil sampling, gamma logging of boreholes, and on-site surface water sampling. Chemical characterization techniques included analysis of composite soil samples for PCBs and hazardous waste characteristics, as defined by RCRA. Discrete samples were also taken and analyzed for PCBs, metals, and other chemical parameters.

Radiological and chemical (i.e., metals) background data were also collected in conjunction with characterization activities to determine the levels of these substances occurring naturally at the Elza Gate site. Samples were obtained from background locations within the city limits of Oak Ridge and Knoxville and analyzed using the same protocols as for the field investigation.

The radiological and chemical survey at Elza Gate consisted of establishing a reproducible grid system, performing gamma radiation walk over surveys, taking near-surface gamma radiation measurements and measurements for radon flux, and conducting subsurface soil investigations, including analyses for uranium-238, radium-226, thorium-232, thorium-230, and several chemicals. A civil surveyor established a $30-\mathrm{m}(100-\mathrm{ft})$ grid that spanned the entire site, except for the five concrete pads; independent survey grids were established for these pads. The initial walk over gamma survey was performed within $15-\mathrm{m}(50-\mathrm{ft})$ subsections of the grid blocks, using an unshielded sodium-iodide, thallium-activated scintillation detector. Areas in which readings exceeded twice background levels were noted on a site drawing. Near-surface gamma radiation was measured $30 \mathrm{~cm}$ (12 in) above the ground, at $3.8-\mathrm{m}(12.5-\mathrm{ft})$ intervals in the areas that were identified as contaminated on the basis of the walk over survey. Gamma exposure rates were measured at $1 \mathrm{~m} \mathrm{(} 3 \mathrm{ft}$ ) above the ground, using a pressurized ionization chamber (PIC).

Subsurface investigations for both radionuclides and chemicals were conducted by drilling and hand-augering holes at most of the $30-\mathrm{m}(100-\mathrm{ft})$ grid intersections. The number and location of boreholes in each area were based on near-surface gamma measurements taken in that area. All soil samples were submitted to established laboratories for analysis.

Six hundred ninety-five soil samples were analyzed for radiological constituents. Borehole locations are shown in Fig. 3. The results indicate that radiological contamination at levels above DOE guidelines is present at a number of locations on the site. A summary of the data is provided in Table 1; the data are shown graphically in Fig. 4. Most of the contamination in soil is adjacent to Pads 1,2, and 4, around the cul-de-sac at the southwest end of Antwerp Lane, and southeast of Antwerp Lane near Pads 1 and 2. The depth of contamination is generally shallow, about $0.15 \mathrm{~m}(0.5 \mathrm{ft})$, with a maximum depth of $1.5 \mathrm{~m}(5 \mathrm{ft})$ at one location 


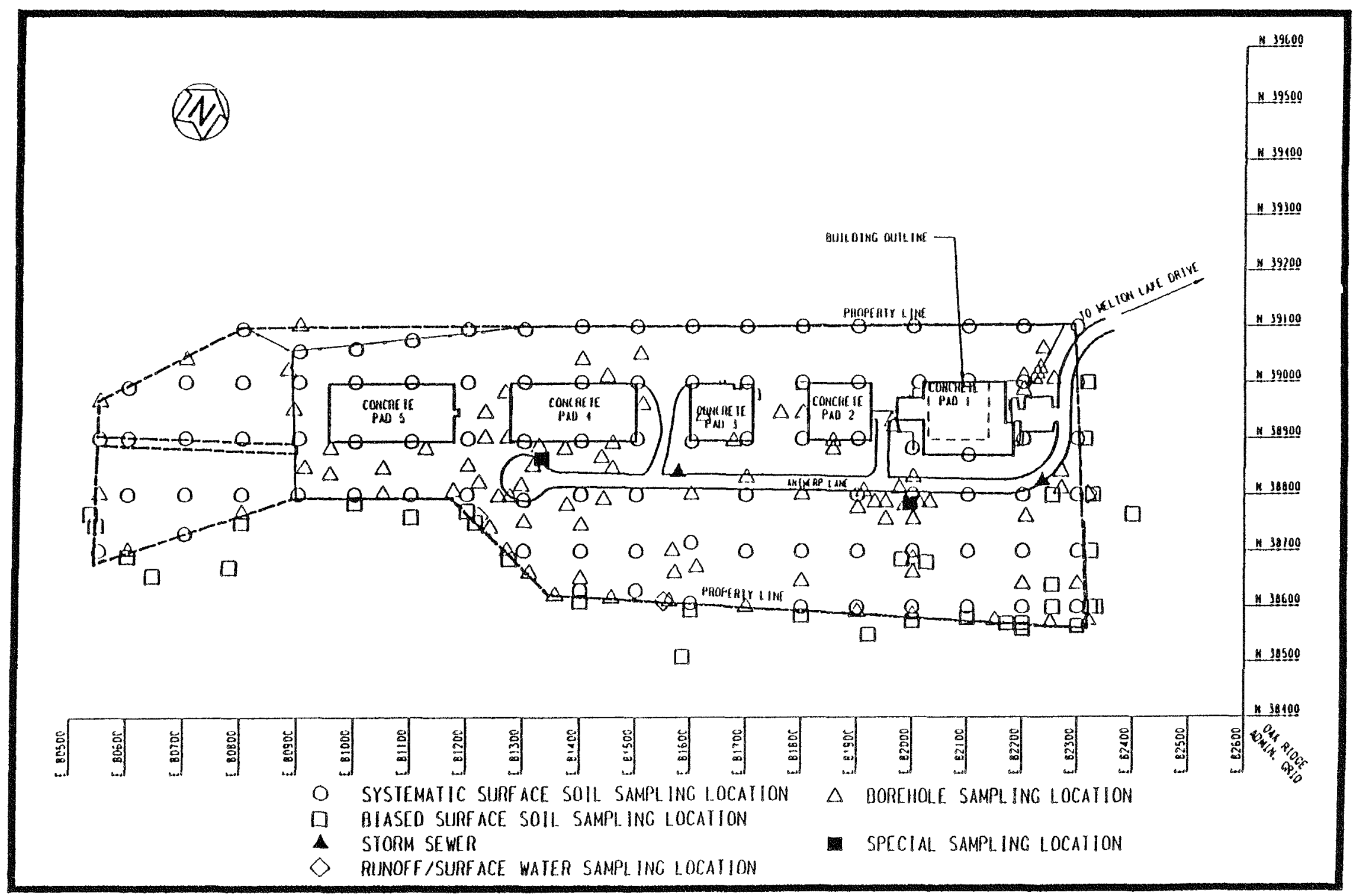

FIGURE 3 Soil-Sampling Locations for the 1989 Radiological Characterization of the Elza Gate Sile (Source: Bechtel National 1991) 
TABLE 1 Summary of Radiological Data from the Elza Gate Site

\begin{tabular}{lcc}
\hline \multicolumn{1}{c}{ Measurement } & Range & Average $^{\mathrm{a}}$ \\
\hline Radionuclide concentration in soil & & \\
(pCi/g) & & \\
Thorium-230 & $0.6-15,000$ & 39.3 \\
Uranium-238 & $<2.0-12,000$ & 38.9 \\
Radium-226 & $0.3-12,000$ & 36.9 \\
Thorium-232 & $0.5-82$ & 2.0 \\
Cesium-137 & $0.036-9.9$ & $<0.7$ \\
& $0-1.5(0-5)$ & $0.15-0.3(0.5-1)$ \\
Depth of contamination (m $[\mathrm{ft}])$ & & 36.3 \\
Gamma radiation exposure & $7.0-571.4$ & \\
rate (microroentgens per hour $[\mu \mathrm{R} / \mathrm{h}])$ & & \\
\hline
\end{tabular}

aSimple averages of all data, irrespective of depth, including background.

bData from Cottrell et al. (1989); averages include values reported at the detection limit.

Source: Bechtel National 1991

south of Pad 4. In general, the highest radionuclide concentrations were of thorium-230, with lower concentrations of uranium-238 and radium-226. Thorium-230 concentrations ranged from less than 1 to $15,000 \mathrm{pCi} / \mathrm{g}$. Uranium-238 and radium-226 concentrations reached $12,000 \mathrm{pCi} / \mathrm{g}$. Cesium-137, identified in the ORNL survey (Cottrell et al. 1989), was not identified in any sample, nor were radionuclides not in the three natural decay series (uranium, thorium, actinium).

An additional 16 soil samples were collected southeast of the Elza Gate site, between the fence and the Melton Lake Reservoir, in October 1990 (Liedle 1990b). The samples were analyzed for uranium-238, radium-226, thorium-232, thorium-230, and PCBs. None of these samples exceeded radiological guidelines set by DOE (see Fig. 5 and Table 2). The judgment arrived at was that contamination requiring action is confined within the fenced site.

Site soil samples were also analyzed for chemical constituents, including volatile organics, base neutral/acid extractable organics, PCBs, cyanide, sulfide, metals and the RCRAdefined hazardous waste characteristics of reactivity, ignitability, corrosivity, and extraction procedure (EP) toxicity. Several samples were also analyzed using the toxicity characteristic leaching procedure (TCLP), which has replaced the EP Toxicity procedure under RCRA. Sampling locations for chemical parameters are shown in Fig. 6.

In general, with the exception of PCBs, organic compounds were detected infrequently and in low concentrations at the site. Two volatile organic compounds, toluene and carbon disulfide, were detected in concentrations that ranged from 8 to 240 parts per billion (ppb) and 6 to $42 \mathrm{ppb}$, respectively. Base neutral/acid extractable organics were not detected at levels greater than the detection limits. 


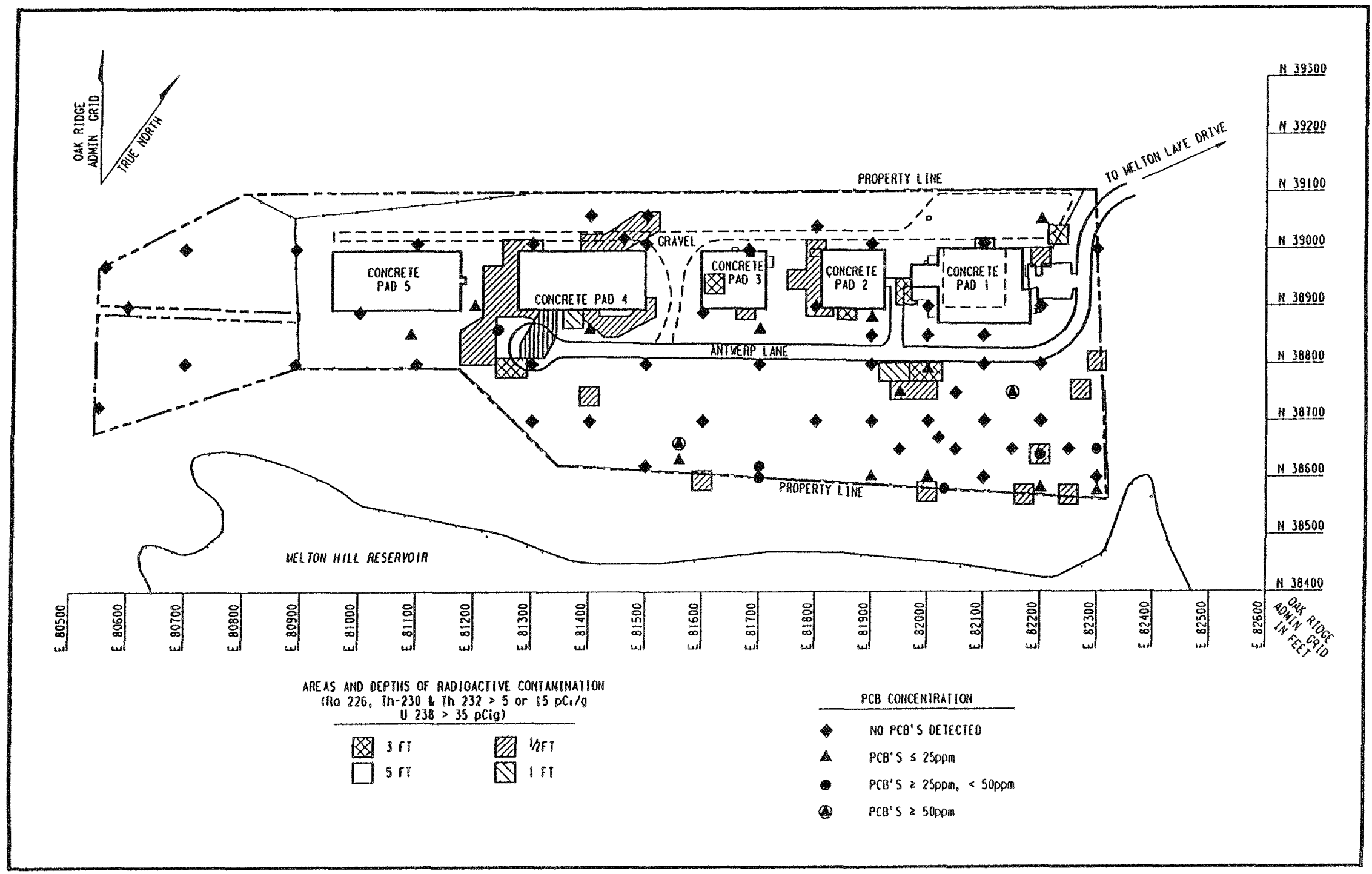

FIGURE 4 Areas of Radiological and PCB Contamination at the Elza Gate Site 


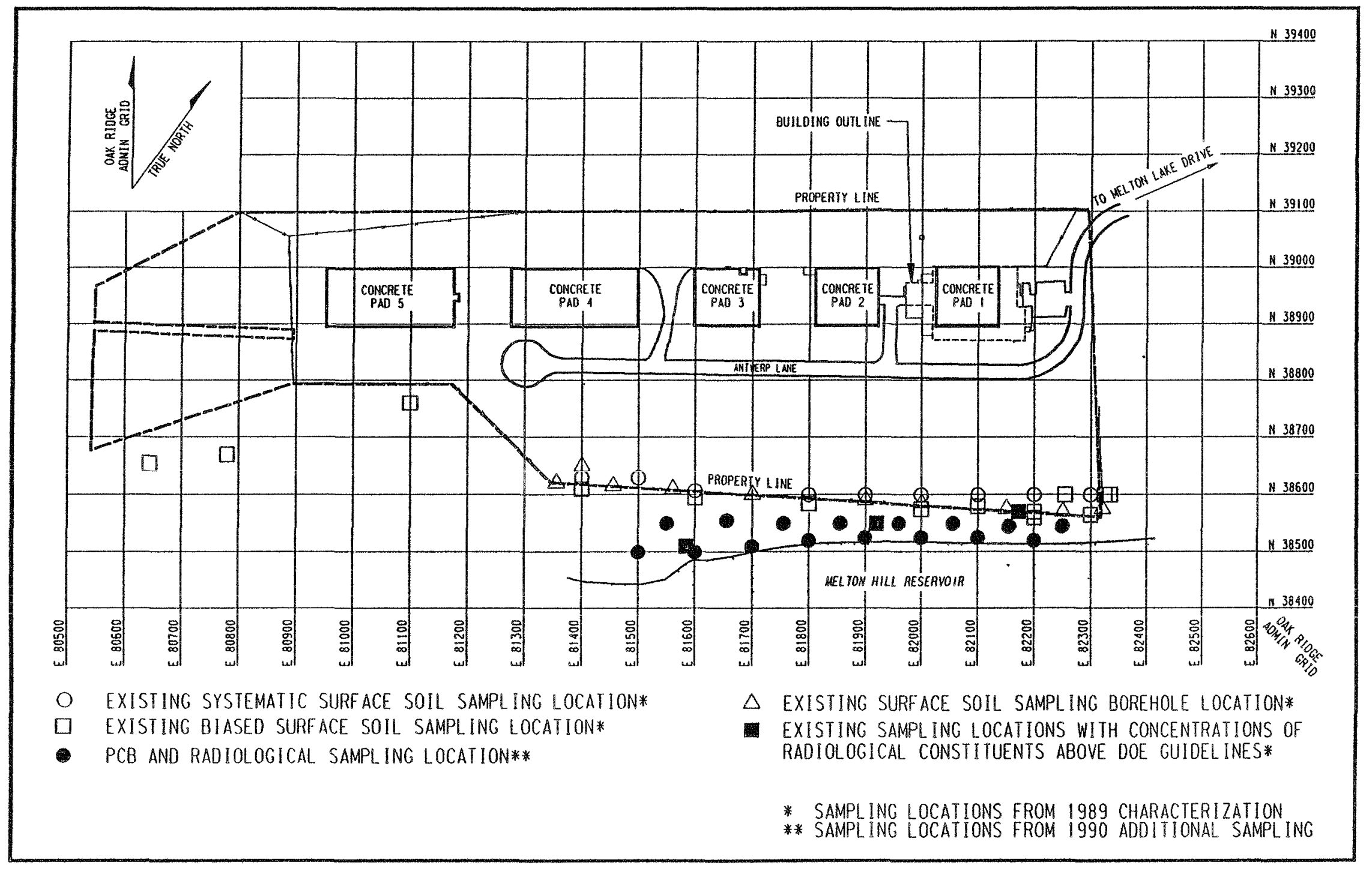

FIGURE 5 Soil-Sampling Locations between the Elza Gate Site and the Melton Lake Reservoir (Source: Liedle 1990b) 
TABLE 2 Radionuclide Concentrations in Soil between the Elza Gate Site and the Melton Lake Reservoir

\begin{tabular}{|c|c|c|c|c|c|c|}
\hline \multirow[b]{2}{*}{ Coordinates } & \multirow{2}{*}{$\begin{array}{l}\text { Borehole } \\
\text { Number }\end{array}$} & \multirow{2}{*}{$\begin{array}{c}\text { Depth } \\
(\mathrm{ft})\end{array}$} & \multicolumn{4}{|c|}{ Concentration ( $\mathrm{pCi} / \mathrm{g} \pm 2$ sigma) } \\
\hline & & & Uranium-238 & Radium-226 & Thorium-232 & Thorium-230 \\
\hline E81500 N38500 & 1 & $0-1$ & $<13.0$ & $<0.7$ & $<1.0$ & $<0.5$ \\
\hline $\mathrm{E} 81550 \mathrm{~N} 38550$ & 2 & $0-1$ & $<13.0$ & $1.3 \pm 0.2$ & $1.7 \pm 0.3$ & $0.7 \pm 0.5$ \\
\hline E81608 N38506 & 3 & $0-1$ & $<8.0$ & $<1.5$ & $2.9 \pm 2.5$ & $0.7 \pm 0.5$ \\
\hline E81650 N38550 & 4 & $0-1$ & $<15.0$ & $1.6 \pm 0.3$ & $1.7 \pm 0.9$ & $1.4 \pm 0.6$ \\
\hline E81722 N38540 & 5 & $0-1$ & $5.7 \pm 4.1$ & $<1.1$ & $<1.5$ & $0.9 \pm 0.6$ \\
\hline E81750 N38550 & 6 & $0-1$ & $<4.0$ & $1.3 \pm 0.2$ & $1.5 \pm 0.6$ & $1.8 \pm 0.7$ \\
\hline E81812 N38535 & 7 & $0-1$ & $<8.0$ & $<1.4$ & $2.6 \pm 1.7$ & $2.9 \pm 0.9$ \\
\hline E81850 N38550 & 8 & $0-1$ & $<6.1$ & $1.6 \pm 0.1$ & $<1.4$ & $1.2 \pm 0.6$ \\
\hline E81900 N38550 & 9 & $0-1$ & $<14.0$ & $1.2 \pm 0.5$ & $1.9 \pm 0.6$ & $1.5 \pm 0.7$ \\
\hline E81950 N38550 & 10 & $0-1$ & $<7.0$ & $<1.2$ & $1.9 \pm 1.2$ & $1.4 \pm 0.7$ \\
\hline E82000 N38535 & 11 & $0-1$ & $<6.0$ & $1.3 \pm 0.5$ & $<3.5$ & $0.8 \pm 0.5$ \\
\hline E82050 N38550 & 12 & $0-1$ & $<6.0$ & $1.3 \pm 0.8$ & $<1.5$ & $0.8 \pm 0.5$ \\
\hline E82100 N38520 & 13 & $0-1$ & $<5.0$ & $1.6 \pm 0.6$ & $1.5 \pm 0.8$ & $1.3 \pm 0.6$ \\
\hline E82150 N38550 & 14 & $0-1$ & $<8.0$ & $<1.4$ & $<1.9$ & $<0.5$ \\
\hline E82200 N38520 & 15 & $0-1$ & $<7.0$ & $1.4 \pm 0.4$ & $<1.6$ & $0.9 \pm 0.6$ \\
\hline E82250 N38550 & 16 & $0-1$ & $<7.0$ & $1.7 \pm 0.7$ & $<1.7$ & $0.9 \pm 0.6$ \\
\hline
\end{tabular}

Source: Liedle 1990b. 


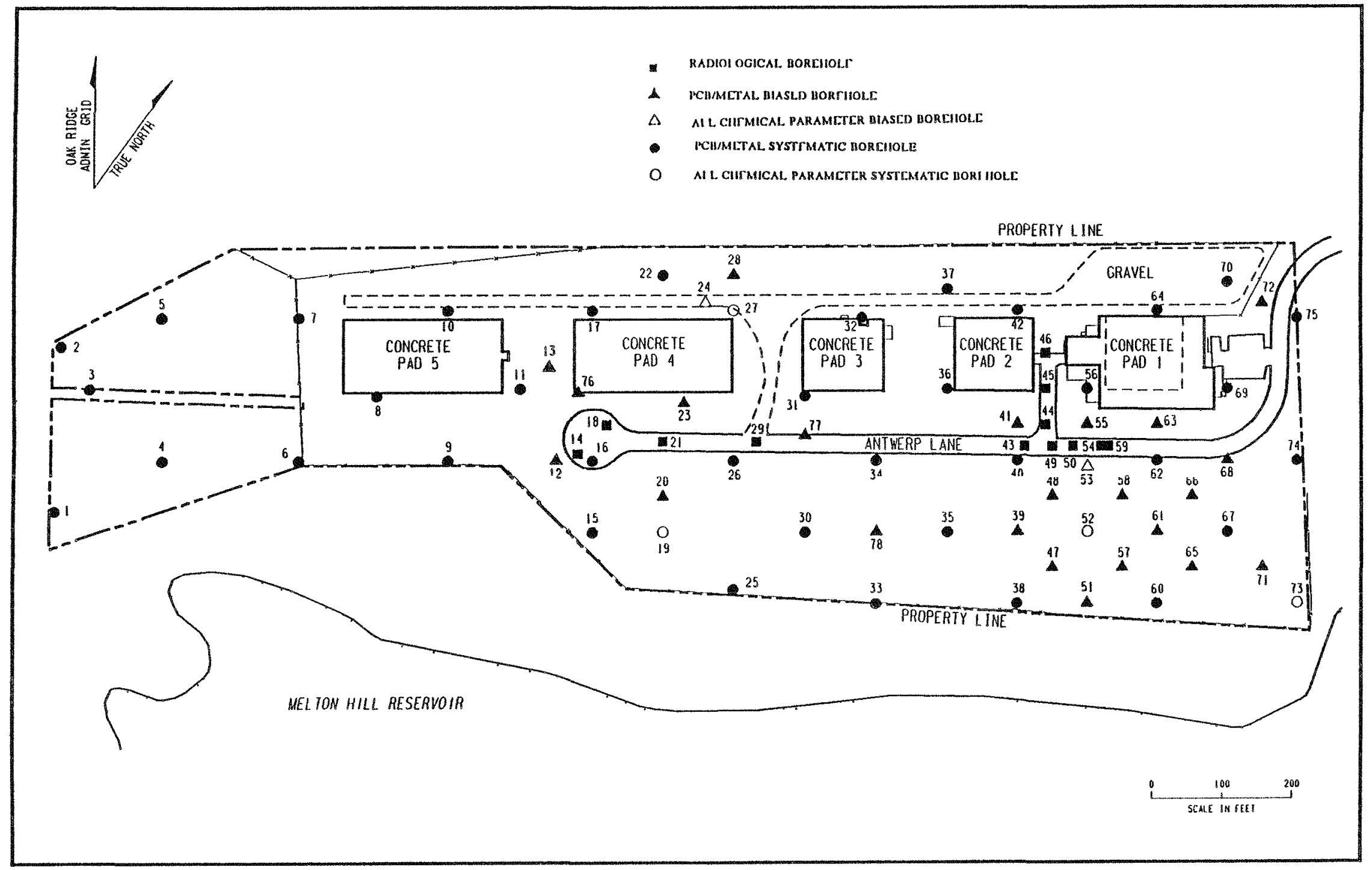

FIGURE 6 Approximate Locations of Chemical and Limited Radiological Sampling Points at the Elza Gate Site 
In 183 discrete soil samples taken from 66 borehole locations, PCBs were detected at concentrations ranging from 0.63 to 69 parts per million (ppm). Previous surveys conducted by ORAU and Bechtel National indicated $\mathrm{PCB}$ concentrations in composite and discrete soil samples ranging from 5 to $170 \mathrm{ppm}$ (Bechtel National 1991). All available PCB data for the site were compiled, and results are shown in Fig. 4 and Table 3. Polychlorinated biphenyl contamination appears to be spotty, with the greatest frequency of occurrence in the southeastern portion of the site. For the most part, PCB contamination is not associated with radiological contamination in soil. PCBs, when detected, were

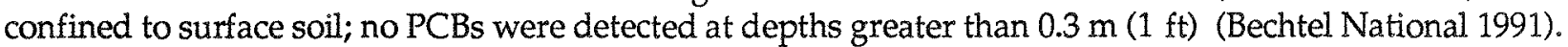
Nine of the samples analyzed for PCBs exceeded $25 \mathrm{ppm}$, and two of these exceeded $50 \mathrm{ppm}$. Of the 16 samples collected between the

TABLE 3 Summary of Metal and PCB Concentrations in Soil at the Elza Gate Site

\begin{tabular}{|c|c|c|c|}
\hline \multirow[b]{2}{*}{ Metal } & \multicolumn{3}{|c|}{ Concentration $(\mathrm{mg} / \mathrm{kg})^{\mathrm{a}}$} \\
\hline & Mean & Minimum & Maximum \\
\hline Arsenic & 39 & 2.4 & 400 \\
\hline Beryllium & 1.4 & 0.10 & 13 \\
\hline Cadmium & 1.5 & 0.10 & 18 \\
\hline Copper & 240 & 0.70 & 7,800 \\
\hline Mercury & 0.50 & 0.10 & 7.7 \\
\hline Manganese & 1000 & 8.7 & 8,500 \\
\hline Molybdenum & 26 & 2.0 & 280 \\
\hline Nickel & 130 & 1.0 & 16,000 \\
\hline Lead & 100 & 0.50 & 4,000 \\
\hline Antimony & 14 & 2.0 & 150 \\
\hline Selenium & 80 & 3.3 & 750 \\
\hline Thallium & 73 & 3.2 & 470 \\
\hline Uranium $^{b}$ & 120 & 5.9 & 36,000 \\
\hline Zinc & 130 & 3.2 & 3,100 \\
\hline $\mathrm{PCBs}^{\mathrm{c}}$ & - & 0.63 & 170 \\
\hline
\end{tabular}

aBased on 183 samples, except for uranium and PCBs. Values rounded to two significant figures. All values, including those reported as the sample detection limit, were included in minimums, maximums, and calculation of the means.

${ }^{b}$ Uranium data obtained from Table 1 of this report and converted to milligrams per kilogram.

'Values are combined data from two Bechtel National surveys and an earlier ORAU survey. Data on total number of samples analyzed and mean PCB levels are not available.

Source: Bechtel National 1991. 
site and the Melton Lake Reservoir, the highest PCB concentration was 5.8 ppm (Liedle 1990b). Polychlorinated biphenyl levels of regulatory significance are discussed in Sec. 1.5.5.

In samples from 66 boreholes, several metals were also detected at levels exceeding background soil concentrations; these include antimony, arsenic, beryllium, cadmium, copper, lead, manganese, mercury, molybdenum, nickel, selenium, thallium, uranium, and zinc. The northwest portion of the site around Pad 5 had the greatest frequency of samples with elevated metal concentrations, although samples with elevated concentrations were scattered across the site. Lead levels of greater than $1000 \mathrm{mg} / \mathrm{kg}$ (equivalent to $1000 \mathrm{ppm}$ ) were detected in 4 samples from depths of $0-1 \mathrm{ft}$ (range of 1250 to $4050 \mathrm{mg} / \mathrm{kg}$ ). The ranges and mean concentrations of metals in Elza Gate soils are given in Table 3.

In initial RCRA characterization tests on composite samples, one sample failed the EP toxicity test for lead. The composite sample obtained north of Pad 4 leached $16.5 \mathrm{mg} / \mathrm{L}$ lead. Excavated soil yielding the same result would be classified as a hazardous waste and be subject to certain disposal restrictions. Subsequently, six composite samples from the site, including a sample from the area that had failed the EP toxicity test for lead, were tested using the TCLP. Lead was not detected in any of these samples, and all results were below regulatory levels that would require classification as hazardous waste (Liedle 1991).

The inorganic compounds cyanide and sulfide were not detected at levels greater than the detection limits. This suggests that cyanide-containing RCRA-listed wastes associated with former metal plating operations are not present at the site.

To characterize the surface of the concrete pads at the site, independent $3-\mathrm{m}(10-\mathrm{ft})$ grids were established. Because previous gamma walk over surveys indicated widespread contamination at Pad 2, an independent grid was not established for this pad, and only a few biased measurements were taken. Direct alpha and beta-gamma surface measurements were taken at each grid intersection, and random locations were surveyed to determine whether contamination was removable. The results of the pad surveys are summarized in Table 4. Data indicate that all the pads have areas of fixed contamination that exceed the DOE guideline for uranium-238 of $5,000 \mathrm{dpm} / 100 \mathrm{~cm}^{2}$ (averaged over $100-\mathrm{cm}^{2}$ sections). Therefore, the pads will require remedial action. The DOE has specified that the uranium- 238 level is the applicable decontamination level. The highest single and average surface contamination measurements were observed on Pad 2, with Pads 1,3,4, and 5 indicating lower levels of contamination (in decreasing order, based upon uranium-238). Results from Pad 5 indicate levels of radioactivity below the designated uranium-238 guideline over most of its surface.

Forty PIC measurements were taken; 17 exceeded the average background exposure rate of $9.3 \mu \mathrm{R} / \mathrm{h}$. In general, the elevated exposure rates corresponded to areas of elevated radium concentrations in soil (i.e., adjacent to Pads 2, 3, and 4, and Antwerp Lane). Eight measurements were taken inside the building on Pad 1; all were below the DOE criterion of $20 \mu \mathrm{R} / \mathrm{h}$ above background for habitable structures (U.S. DOE 1990a)

Twenty-seven radon flux measurements were taken at the site; these ranged from 0.05 to $159 \mathrm{pCi} / \mathrm{m}^{2} / \mathrm{s}$. Four of the measurements were above the average measured background for the area $\left(12 \mathrm{pCi} / \mathrm{m}^{2} / \mathrm{s}\right)$, and one was above the DOE guideline of $20 \mathrm{pCi} / \mathrm{m}^{2} / \mathrm{s}$ for long-term management of uranium and thorium wastes (U.S. DOE 1990a). Elevated radon flux measurements corresponded to the locations of high radium concentrations in soil. 
TABLE 4 Direct Radiation Measurements on the Pads at the Elza Gate Site $\left(\mathrm{dpm} / 100 \mathrm{~cm}^{2}\right)$

\begin{tabular}{|c|c|c|c|c|c|c|c|c|}
\hline \multirow[b]{2}{*}{ Area } & \multicolumn{4}{|c|}{ Beta-Gamma } & \multicolumn{4}{|c|}{ Alpha } \\
\hline & Maximum & Minimum & Average & $\begin{array}{c}\text { Number of } \\
\text { Measurements }\end{array}$ & Maximum & Minimum & Average & $\begin{array}{l}\text { Number of } \\
\text { Measurements }\end{array}$ \\
\hline Pad 1 & 131,010 & $<480$ & 12,830 & 290 & 17,240 & $<7$ & 1,350 & 290 \\
\hline $\begin{array}{c}\text { Southeast wall } \\
\text { of building }\end{array}$ & $<650$ & $<559$ & 620 & 11 & $<50$ & $<20$ & 40 & 11 \\
\hline $\begin{array}{c}\text { Northeast wall } \\
\text { of building }\end{array}$ & $<940$ & $<559$ & 690 & 7 & $<50$ & $<20$ & 40 & 7 \\
\hline $\begin{array}{c}\text { Northwest wall } \\
\text { of building }\end{array}$ & 1,290 & $<559$ & 660 & 11 & $<50$ & $<20$ & 30 & 11 \\
\hline $\begin{array}{c}\text { Southwest wall } \\
\text { of building }\end{array}$ & $<990$ & $<559$ & 640 & 7 & $<50$ & $<20$ & 30 & 7 \\
\hline Pad 2 & $1,643,050$ & 1,590 & 227,250 & 47 & 242,870 & 390 & 30,270 & 47 \\
\hline Pad 3 & 97,630 & $<550$ & 4,340 & 132 & 6,130 & 20 & 120 & 132 \\
\hline Pad 4 & 57,510 & 560 & 3,280 & 252 & 6,530 & 17 & 350 & 252 \\
\hline Pad 5 & 4,900 & $<550$ & 970 & 250 & 5,370 & 20 & 70 & 250 \\
\hline
\end{tabular}

Source: Bechtel National 1991. 
As a result of the surveys conducted at the site, it is estimated that a total volume of $8,360 \mathrm{~m}^{3}\left(10,940 \mathrm{yd}^{3}\right)$ of contaminated material will require management as waste. Of this waste, it is estimated that a total of $5,495 \mathrm{~m}^{3}\left(7,190 \mathrm{yd}^{3}\right)$ is radiologically contaminated material (soil and rubble); that $670 \mathrm{~m}^{3}\left(875 \mathrm{yd}^{3}\right)$ is radiologically contaminated soil with PCB levels of from 25 to $50 \mathrm{ppm}$; that $1,145 \mathrm{~m}^{3}\left(1,500 \mathrm{yd}^{3}\right)$ is soil contaminated with PCBs only, at levels of 25 to $50 \mathrm{ppm}$; that $380 \mathrm{~m}^{3}\left(500 \mathrm{yd}^{3}\right)$ is soil containing lead at levels greater than $1000 \mathrm{ppm}$ (see Sec. 1.5.5); and that $670 \mathrm{~m}^{3}\left(875 \mathrm{yd}^{3}\right)$ is soil contaminated with PCBs only, at levels greater than 50 ppm. No radiological waste containing PCBs at greater than $50 \mathrm{ppm}$ has been identified in site characterization.

\subsection{SITE CONDITIONS THAT JUSTIFY A. REMOVAL ACTION}

The overall objective of the proposed removal action at the Elza Gate site is to eliminate, reduce, or otherwise mitigate the potential for exposure to radioactive and chemical contaminants in order to minimize threats to human health and the environment resulting from such exposure. The primary threat relates to the potential for uncontrolled releases of contaminants from exposed surfaces and subsurface areas via precipitation/runoff, wind dispersal, leaching to groundwater, or disturbance by humans or animals. The removal and disposal of contaminated soil and concrete from the site are essential for the long-term protection of human health and the environment in the area.

The DOE has evaluated the Elza Gate site in accordance with radiological protection guidelines that have been developed to protect human health and the environment; these guidelines are stated in DOE Order 5400.5. A number of potential exposure pathways are addressed by the guidelines, including:

- Residual radionuclide concentrations in soil material,

- External gamma radiation levels,

- Surface contamination levels, and

- Radionuclide concentrations in air and water.

The basic dose limit established by DOE for the annual radiation dose received by an individual member of the public is 100 millirems per year (mrem/yr). It is DOE policy to ensure that actual doses to the public are as far below this basic dose limit as is reasonably achievable. The threats posed by the contamination at the Elza Gate site are not time-critical; that is, no imminent or substantial endangerment of human health or welfare and the environment currently exists at the site that would necessitate emergency cleanup.

The Elza Gate site has been surveyed for external gamma radiation levels, surface contamination levels, residual radionuclide concentrations in soil, surface water concentrations, and radon flux levels. The primary radioactive contaminants of concern in soil are uranium-238, thorium-230, and radium-226. Radiologically contaminated areas were evaluated on the basis of compliance with guidelines and the basic dose limit. To justify removal of the contaminated materials, the survey results are compared with DOE guidelines in Secs. 1.5.1 through 1.5.4. 
In addition to radiological evaluation of the Elza Gate site, the public health significance of chemical contamination has also been evaluated. The chemical contaminants of concern are PCBs and several metals. Chemical levels are compared with available federal guidelines in Sec. 1.5.5 to justify any removal on the basis of chemical contamination.

\subsubsection{External Gamma Radiation}

The DOE guidelines state that external gamma radiation levels on open lands shall comply with the basic dose limit of $100 \mathrm{mrem} / \mathrm{yr}$, considering an appropriate-use scenario for the area. Compared to an average background exposure rate of $9.3 \mu R / h, 7$ of the 40 exposure rate measurements taken at the Elza Gate site were above twice background. Gamma exposure rates ranged from $7 \mu \mathrm{R} / \mathrm{h}$ to $571.4 \mu \mathrm{R} / \mathrm{h}$. The highest gamma exposure rate occurred at the northern side of the cul-de-sac, which coincides with the area where the highest uranium-238 and radium-226 concentrations in soil were detected. The average gamma exposure rate at the Elza Gate site was $36 \mu \mathrm{R} / \mathrm{h}$. Eight of the 40 measurements were taken inside the building; all eight were below the DOE criterion of $20 \mu \mathrm{R} / \mathrm{h}$ above background for habitable structures.

\subsubsection{Residual Concentrations of Radionuclides in Soil}

The principal radionuclides of concern at Elza Gate are uranium-238, thorium-230, and radium-226. Cesium-137 was also identified in the ORNL survey (Cottrell et al. 1989). The guidelines for residual concentrations of radium-226 and thorium-230 in soil material state that the concentrations shall not exceed $5 \mathrm{pCi} / \mathrm{g}$ when averaged over the first $15 \mathrm{~cm}$ (6 in.) of soil below the surface; and further, that the concentrations shall not exceed $15 \mathrm{pCi} / \mathrm{g}$ when averaged over any 15-cm- (6-in.-) thick soil layer below the surface layer. These guidelines represent allowable residual concentrations above background averaged across any 15-cm- (6-in.-) thick layer to any depth and over any contiguous $100-\mathrm{m}^{2}\left(1075-\mathrm{ft}^{2}\right)$ surface area. For mixtures of radionuclides, the sum of the ratios of the concentration of each radionuclide to the guideline for that radionuclide shall not exceed 1 .

The DOE does not use generic guidelines for uranium in soil; the uranium guideline is calculated on a site-specific basis. The DOE has developed a cleanup guideline value of $35 \mathrm{pCi} / \mathrm{g}$ for uranium-238 in soil (Wagoner 1991).

Soil sampling results indicated that the maximum depth of contamination was $1.5 \mathrm{~m}$ $(5 \mathrm{ft})$. At the Elza Gate site, the volume-weighted average concentrations of thorium- 230 and radium-226 were 242 and $194 \mathrm{pCi} / \mathrm{g}$, respectively, from the surface to a depth of $0.3 \mathrm{~m}(1 \mathrm{ft})$. These concentrations exceed the DOE residual contamination guidelines for thorium- 230 and radium-226. The peak values were 15,000 and $12,000 \mathrm{pCi} / \mathrm{g}$, respectively. Also, uranium-238 exceeded the guideline value of $35 \mathrm{pCi} / \mathrm{g}$. The volume-weighted average concentration of uranium-238 in the soil was $182 \mathrm{pCi} / \mathrm{g}$, with a peak of $12,000 \mathrm{pCi} / \mathrm{g}$. Cleanup of the Elza Gate site is proposed on the basis of residual concentrations of uranium-238, radium-226, and thorium-230 in soil that exceed the guidelines for the protection of human health and the environment. It is assumed that the cesium-137 found by ORNL was in a localized hot spot since it was not found in any of Bechtel's 695 soil sample results. Cesium-137 will not be treated as a contaminant of concern. Removal action activities at the Elza Gate site will be conducted in compliance with all aspects of the DOE guidelines. 


\subsubsection{Radon Flux Levels}

The DOE guidelines for long-term management of residual radioactive material at FUSRAP sites state that a radon-222 emanation to the atmosphere from such material shall not exceed an annual average release rate of $20 \mathrm{pCi} / \mathrm{m}^{2} / \mathrm{s}$. The radon flux measured at the site ranged from 0.07 to $159 \mathrm{pCi} / \mathrm{m}^{2} / \mathrm{s}$, with an average of $12 \mathrm{pCi} / \mathrm{m}^{2} / \mathrm{s}$. The average background flux rate for the site was measured as $0.2 \mathrm{pCi} / \mathrm{m}^{2} / \mathrm{s}$, and 16 of the 27 samples measured were above background. The above-background flux measurements correspond to areas containing high concentrations of radium-226; for example, the area near Pad 4 and the cul-de-sac. This area also coincides with the highest gamma exposure rates for the site.

\subsubsection{Surface Contamination}

The DOE guidelines for allowable total residual surface contamination for uranium-238 are 5,000 dpm/100 $\mathrm{cm}^{2}$ average, $15,000 \mathrm{dpm} / 100 \mathrm{~cm}^{2}$ maximum, and 1,000 dpm/100 $\mathrm{cm}^{2}$ removable. The DOE has made a determination for this site that the uranium-238 guideline is the applicable guideline.

Direct alpha and beta-gamma radiation measurements were taken on Pads 1 through 5. The average measured alpha activities ranged from 70 to $30,270 \mathrm{dpm} / 100 \mathrm{~cm}^{2}$, and the average measured beta-gamma activities ranged from 970 to $227,250 \mathrm{dpm} / 100 \mathrm{~cm}^{2}$. All five pads were also surveyed for removable contamination. The average removable radioactivity ranged from 7 to $300 \mathrm{dpm} / 100 \mathrm{~cm}^{2}$ for alpha activity and 100 to $320 \mathrm{dpm} / 100 \mathrm{~cm}^{2}$ for beta-gamma activity. Guidelines would be $20 \mathrm{dpm} / 100 \mathrm{~cm}$ for thorium-230 and radium-226 alpha activity, and $1000 \mathrm{dpm} / 100 \mathrm{~cm}^{2}$ for uranium-238 beta-gamma activity. Survey data indicated that all of the pads have above-guideline areas of radioactive contamination. Pad 2 had the highest measurements of surface contamination (based on uranium-238 guidelines). Results of samples from Pads 1, 3, 4, and 5 indicated respectively lower levels of contamination; Pad 5 measurements were below the uranium-238 guidelines over most of the pad's surface.

\subsubsection{Chemical Contamination Levels}

Polychlorinated biphenyls are the primary chemical contaminants of concern at Elza Gate. The state of Tennessee does not have guidelines for cleanup levels of PCBs in soil. However, the U.S. Environmental Protection Agency (EPA) implements the Toxic Substances Control Act (TSCA), which is used to regulate PCBs in Tennessee, and requires remedial action for soils contaminated with PCBs at greater than $50 \mathrm{ppm}$. The cleanup levels employed are those given for restricted access areas in Title 40, Code of Federal Regulations (CFR), Part 761.125, Section (c). All soil at the site containing PCBs at levels exceeding $50 \mathrm{ppm}$ will be managed and disposed of in accordance with the TSCA. Soil with a PCB level greater than 25 ppm but less than $50 \mathrm{ppm}$ will be excavated and managed in the same manner as radiologically contaminated soil. Soil with a PCB level less than $25 \mathrm{ppm}$ is not required to be managed in a specific manner. No off-site soil has been found to contain a PCB level greater than $25 \mathrm{ppm}$. Because the levels of PCBs at the Elza Gate site are generally low, there is no immediate threat to human health or welfare and the environment. However, remedial action as required by the TSCA is warranted on the basis of the potential future threat that PCB contamination may pose to employees at Elza Gate and residents of the area. 
For metal constituents in soils, levels of regulatory concern are currently established by conducting the TCLP test (the EP toxicity test was formerly used). Although the average levels of several metals in Elza Gate soils are elevated, the results of TCLP testing do not indicate that these soils, when excavated, would be classified as hazardous wastes.

The EPA has also established an interim soil cleanup level for lead in soil of 500 to 1000 ppm (EPA 1989b). This range is considered protective for direct contact at residential settings. Because residential use is not expected to be the future use of the Elza Gate site, the upper end of this range is selected as a target guideline for the site -- that is, $1000 \mathrm{ppm}$. Four site samples exceeded this criterion; three of these samples were from the southwest corner of the site, south of Pad 5; the other was obtained at the southwest central site border. Although not classified as hazardous under RCRA, soils with lead levels greater than $1000 \mathrm{ppm}$ will be excavated and disposed of in accordance with the EPA interim soil cleanup level.

To evaluate the public health significance of the proposed removal action with respect to other potentially toxic metals found at elevated levels in Elza Gate soils (i.e., those listed in Sec. 1.4), exposure of a remediation worker and a potential future resident will be estimated and compared with health criteria (see Sec. 4.3.1).

\subsection{POTENTIAL EXPOSURE PATHWAYS}

\subsubsection{Contaminants of Concern}

Sampling results at the Elza Gate site and the history of site activities indicate that the contaminants of concern are uranium-238, thorium-230, radium-226, PCBs, and several metals. Fourteen metals were selected on the basis of elevated levels and toxicity (see Table 3 ).

The two main hazards associated with exposure to uranium compounds are kidney damage caused by the chemical toxicity of soluble uranium compounds and potential cancer caused by ionizing radiation resulting from the radioactive decay of uranium decay products. The major health risk from uranium, however, is the result of its chemical rather than radiological properties. Deposition of uranium dust particles in the lungs via inhalation depends on particle size; absorption depends on the solubility of the compound. The absorption level of uranium compounds following oral exposure is generally considered to be low.

Thorium is a carcinogen and poses a radiological hazard. The major exposure pathway of concern for thorium is inhalation. Most thorium ingested in food, water, or soil is excreted within a few days, and only a small fraction is absorbed into the bloodstream (Seiler and Sigel 1988). Depending on its molecular form, thorium will be removed from the lung over a time period on the order of weeks to years. Once in the bloodstream, thorium accumulates on bone surfaces, where it can persist for several years; hence, bone cancer is a potential health concern. Studies have shown that, while soluble forms are absorbed to a greater degree than insoluble forms, no chemical form of thorium is absorbed in appreciable amounts from the gastrointestinal tract.

Contamination at the Elza Gate site also includes radium-226. The principal exposure pathway of concern for radium is ingestion. When radium is taken into the body, its metabolic behavior is similar to that of calcium. An appreciable fraction of ingested radium is deposited 
nonuniformly into the bone, where it irradiates cells of that tissue. The release of radium from the bone is slow; thus, chronic intake can lead to very high concentrations, potentially resulting in bone cancer.

Polychlorinated biphenyls constitute a class of chemicals that were commonly used as coolants and lubricants in electrical equipment such as transformers until the late $1970 \mathrm{~s}$. Use of PCBs was stopped because they were found to accumulate in the fatty tissues of edible plants and animals and to be associated with adverse health effects such as skin irritation, liver damage, reproductive and developmental effects, and cancer. Polychlorinated biphenyls may pose a chemical hazard via ingestion, inhalation, or dermal contact (i.e., adsorption through the skin).

The metals of potential concern in site soil are listed in Table 3. Exposure to these metals could occur via inhalation or ingestion. Dermal absorption from soil is expected to be insignificant. Some of the metals (e.g., copper and zinc) are essential in the human diet and only cause toxicity when exposure levels are high. Other metals (e.g., antimony, arsenic, lead, and thallium) can cause toxic effects such as liver, lung, and kidney disease, nervous system toxicity, and anemia at lower exposure levels.

\subsubsection{Release Mechanisms}

Possible threats to human health or welfare and the environment associated with the Elza Gate site are related to the potential release of radioactive and chemical material from contaminated soil or concrete pads. Possible release mechanisms may include surface runoff, leaching to groundwater, resuspension of contaminated soil particles into the air by wind action or soil disturbance during excavation (mechanical resuspension), and possible uptake of contaminants from soil into plants and animals, and subsequent entry into the food chain.

\subsubsection{Environmental Fate}

The environmental fate of a released contaminant depends on both its physicochemical properties and the nature of the environmental medium in which it occurs. The environmental fate of each contaminant or group of contaminants of concern is discussed below.

The mobility of radionuclides in soil depends on soil properties such as $\mathrm{pH}$, oxidationreduction potential, concentration of complexing anions, and sorption properties. Under neutral $\mathrm{pH}$ conditions, radium, uranium, and thorium can be ranked, respectively, as relatively mobile, moderately mobile, and strongly immobile. Mobility increases with increasing acidity.

Polychlorinated biphenyls may slowly biodegrade in soils or may volatilize from soil surfaces. They also bind strongly to soil particles; for this reason, they are not likely to leach into groundwater.

Metal compounds can undergo a wide range of transformation processes and thus can form complexes with inorganic species or organic ligands present in the environment. These processes, collectively referred to as speciation, can occur in all environmental media. The speciation of a metal in a given environment affects its bioavailability, solubility, volatility, and sorptive properties. In addition to speciation, the fate of metals is affected by the properties of 
the environmental media. For example, properties affecting the mobility of a metal compound in soil include the cation exchange capacity and the $\mathrm{pH}$ of the soil; the solubility of a metal in water depends on the presence of other chemical species and on the $\mathrm{pH}$.

\subsubsection{Potential Receptors}

Under current conditions, potential receptors for contaminants from the Elza Gate site may include on-site workers, trespassers, persons at nearby industrial and residential properties, and workers conducting the removal action described in this EE/CA. Currently, the principal receptors of concern are the workers who would conduct the removal action. If future use of the Elza Gate site includes residents living on the site, they would also be potential receptors. However, near-term use of the site is not expected to be residential, since the site is in an area of current commercial and industrial development.

\subsubsection{Potential Risks}

In the near term, and in the absence of remedial action at the site, the primary potential for human exposure to contaminants is direct external exposure to gamma radiation from radium-226. In addition, radioactive, PCB-contaminated, and metal-contaminated soils could be dispersed into the air by mechanical resuspension or wind erosion, leading to inhalation of these contaminants. Incidental soil ingestion is unlikely to be a substantial exposure pathway in the near term for three reasons: the site is not residential; employees at industrial plants work primarily indoors; and removal action workers, who will have the most potential for contact with the contaminated soil, are trained and equipped to avoid this route of intake. However, incidental soil ingestion or ingestion of contaminants bioaccumulated in garden vegetables could be significant intake routes for potential future residents. Finally, dermal uptake of radionuclides and metals from a soil medium is expected to be minimal. However, dermal uptake of PCBs from soil is possible for someone having extensive soil contact.

Exposure to site contaminants from the ingestion of contaminated drinking water is not a concern for the Elza Gate site for several reasons. Groundwater under the site is not used for drinking; rather, the drinking water supply for area residents comes from the Clinch River and is municipally treated. In addition, many of the contaminants at the site, such as PCBs and some metals, form insoluble complexes in soil that are unlikely to leach into groundwater.

The release of radioactive and chemical contaminants from the site could affect local ecosystems. Transient or permanent populations of animals that occupy the site area are currently being exposed to low levels of radioactivity and chemicals from contaminated soil and surfaces through inhalation, ingestion, and direct exposure. Contamination that migrates via runoff to nearby surface waters could result in the exposure of animals that reside in or drink

the surface water. For example, the Melton Lake Reservoir, which might receive runoff from the site, is located adjacent to the southeastern border of the site and connects to the Clinch River near the northeast end of the site. These potential ecological impacts, while expected to be small in the short term, provide further justification for a removal action at the site. 


\section{REMOVAL ACTION OBJECTIVES}

\subsection{STATUTORY AUTHORITY}

Authority for responding to releases or threats of releases from a hazardous waste site is addressed in Sec. 104 of the Comprehensive Environmental Response, Compensation, and Liability Act (CERCLA) of 1980, as amended. Executive Order 12580 delegates to the DOE the response authority for DOE sites, whether or not the sites are on the National Priorities List of the EPA. Under CERCLA Sec. 104(b), the DOE is authorized to investigate, survey, test, or gather other data required to identify the existence, extent, and nature of contaminants, including the extent of danger to human health or welfare and the environment. In addition, the DOE is authorized to undertake planning, engineering, and other studies or investigations appropriate to directing response actions that prevent, limit, or mitigate the risk to human health or welfare and the environment.

\subsection{SCOPE AND PURPOSE}

The scope of the proposed removal action can be broadly defined as management of radiologically or chemically contaminated materials at the Elza Gate site. The specific objectives are:

- Remediation of contamination at the site to eliminate current and future potential hazards to human health or welfare and the environment;

- Breaking up of concrete pads and segregating into radioactively contaminated and uncontaminated material and packaging of the contaminated rubble;

- Excavation of soils that contain radiological contaminants at levels exceeding DOE guidelines or PCB concentrations between 25 and 50 ppm, or lead concentrations exceeding $1000 \mathrm{ppm}$, with subsequent storage or disposal of these soils;

- Excavation and off-site commercial disposal of soil with PCB concentrations exceeding 50 ppm; and

- Certification of the site for use without radiological restrictions.

\subsection{SCHEDULE}

The proposed removal action at the Elza Gate site is tentatively scheduled to start in July 1991; completion is scheduled for October 1991. A public comment period of 30 days has been included in this schedule. Implementation time for the recommended removal action alternative (see Sec. 5) includes removing contaminated materials, backfilling with clean topsoil or other appropriate material, transporting the radiological and nonhazardous chemically contaminated materials to the ORR for disposal or storage, transporting PCB wastes to an 
appropriate disposal facility in compliance with TSCA regulations, and, if necessary, constructing an interim storage facility.

\subsection{COMPLIANCE WITH REGULATORY REQUIREMENTS}

Pursuant to Sec. 300.415(i) of the National Oil and Hazardous Substances Pollution Contingency Plan (NCP), removal actions are required to meet, to the extent practicable considering the exigencies of the situation, all federal and state applicable or relevant and appropriate requirements (ARARs) (U.S. EPA 1990). The NCP also notes that requirements are ARARs only when they pertain to the specific removal action being conducted.

Potential requirements for a proposed removal action can be grouped into two general categories - ARARs and to-be-considered (TBC) requirements. The first category consists of promulgated standards - for example, public laws codified at the state or federal level - that may be applicable to a proposed action or relevant and appropriate to all or part of that action. The second category consists of standards or guidelines that have been published but not promulgated and that may have significance for all or part of the action. (DOE orders are not promulgated standards and, therefore, are treated as TBC requirements even though such orders are applicable to all DOE actions.) Potential TBC requirements are typically considered only if no promulgated requirements exist that are either applicable or relevant and appropriate. The removal action at the Elza Gate site will be conducted in accordance with both ARARs and TBCs, as appropriate.

Guidance from the EPA (1987b) defines applicability as implying that the proposed action or site circumstances satisfy all of the jurisdictional prerequisites of the requirement. Relevant and appropriate requirements are defined as those that address problems or situations sufficiently similar to those encountered at the site in question that their use is well suited to the particular site. Any standard, requirement, criterion, or limitation under any federal or state law may be considered either applicable or relevant and appropriate to a specific action. The only state laws that may become ARARs are those that are (1) promulgated such that they are legally enforceable and generally applicable (i.e., consistently applied) and (2) more stringent than federal laws. A determination of applicability is made for the requirement as a whole, whereas a determination of relevance and appropriateness may be made for only specific portions of a requirement. An action must comply with relevant and appropriate requirements to the same extent as an applicable requirement with regard to substantive conditions, but need not comply with the administrative conditions of the requirement.

The ARARs are divided into three categories: (1) contaminant-specific ARARs address certain contaminants or a class of contaminants and relate to the level of contamination allowed for a specific pollutant in various environmental media (i.e., soil, water, and air); (2) locationspecific ARARs are based on the specific setting and nature of the site; and (3) action-specific ARARs relate to specific response actions proposed for implementation at a site. The preliminary identification of potential ARARs for the proposed removal action at the Elza Gate site is based on the nature of the contamination (primarily soil contaminated with radionuclides of the thorium-232 and uranium-238 decay series). Environmental statutes, executive orders, and DOE orders potentially pertinent to the proposed action are presented in Tables 5 and 6 . Actual determinations of whether ARARs or TBCs are applicable (or potentially applicable) or relevant and appropriate (or potentially relevant and appropriate) are presented in Tables A.1, A.2, and A.3 of the Appendix. 
TABLE 5 Federal Statutes, Executive Orders, and DOE Orders Potentially Pertinent to the Proposed Removal Action at the Elza Gate Site

Laws

Antiquity Act/Historic Sites Act

Archeological and Historic Preservation Act of 1974

Archeological Resources Protection Act of 1979

Atomic Energy Act of 1954, as amended

Clean Air Act of 1963, as amended

Clean Water Act, as amended (also referred to as Federal Water Pollution Control Act of 1972, as amended)

Comprehensive Environmental Response, Compensation, and Liability Act of 1980, as amended by

the Superfund Amendments and Reauthorization Act of 1986

Department of Energy Organization Act of 1977

Endangered Species Act of 1973, as amended

Fish and Wildlife Coordination Act of 1934, as amended

Hazardous Materials Transportation Act of 1974, as amended

National Historic Preservation Act of 1966, as amended

Noise Control Act of 1972

Noise Pollution and Abatement Act of 1970

Occupational Safety and Health Act of 1970

Safe Drinking Water Act of 1974, as amended

Solid Waste Disposal Act, as amended by the Resource Conservation and Recovery Act of 1976, as amended by the Hazardous and Solid Waste Amendments of 1984

Toxic Substances Control Act of 1976

Uranium Mill Tailings Radiation Control Act of 1978, as amended

\section{Executive Orders}

Executive Order 11490, Assigning Emergency Preparedness Functions to Federal Departments and Agencies

Executive Order 11514, Protection and Enhancement of Environmental Quality

Executive Order 11593, Protection and Enhancement of the Cultural Environment

Execubive Order 11738, Providing for Administration of the Clean Air Act and the Federal Water

Pollution Control Act with Respect to Federal Contracts, Grants, or Loans

Executive Order 11807, Occupational Safety and Health Programs for Federal Employees

Executive Order 11988, Floodplain Management

Executive Order 11990, Protection of Wetlands

Executive Order 11991, Relating to the Protection and Enhancement of Environmental Quality

Executive Order 12088, Federal Compliance with Pollution Control Standards

Executive Order 12146, Management of Federal Legal Resources

Executive Order 12580, Superfund Implementation 
TABLE 5 (Cont'd)

\section{Department of Energy Orders}

Order 1540.1 Materials Transportation and Traffic Management

Order $4240.1 \mathrm{H}$ Designation of Major System Acquisition and Major Projects

Order 4320.1A Site Development and Facility Utilization Planning

Order 4700.1 Project Management System

Order 5400.1 General Environmental Protection Program

Order 5400.3 Hazardous and Radioactive Mixed Waste Management (was Chapter II of 5480.1A)

Order 5400.4 Comprehensive Environmental Response, Compensation, and Liability Act Program

Order 5400.5 Radiation Protection of the Public and the Environment

Order 5440.1C Implementation of the National Environmental Policy Act

Order 5480.1B Environment, Safety, and Health Program for Department of Energy Operations

Order 5480.3 Safety Requirements for the Packaging and Transportation of Hazardous Materials,

Hazardous Substances, and Hazardous Wastes (was Chapter III of 5480.1A)

Order 5480.4 Environmental Protection, Safety, and Health Protection Standards

Order 5480.11 Radiation Protection for Occupational Workers

Order 5481.1B Safety Analysis Review System

Order 5482.1B Environmental Protection, Safety, and Health Protection Appraisal Program

Order 5483.1A Occupational Safety and Health Program for DOE Employees at Government-Owned

Contractor-Operated Facilities

Order 5484.1 Environmental Protection, Safety, and Health Protection Information Reporting

Requirements

Order 5000.3 Unusual Occurrence Reporting System

Order 5500.2 Emergency Planning, Preparedness, and Response for Operations

Order 5700.6B Quality Assurance

Order 5820. 2 Radioactive Waste Management

TABLE 6 State Statutes Potentially Pertinent to the Proposed Removal Action at the Elza Gate Site

Tennessee Solid Waste Disposal Act, Tenn. Code, Title 68, Chapter 31

Tennessee Hazardous Waste Management Acts, Tenn. Code, Title 68, Chapter 46

Tennessee Hazardous Waste Management Rules, Tenn. Dept. of Public Health Rules, Chapter 1200-1

Tennessee Water Quality Control Act, Tenn. Code, Title 69, Chapter 3

Tennessee Water Quality Criteria, Rules and Regulations of Tenn., Chapters 1200-4, Dept. of Health, Rule 3

Tennessee Effluent Limitations and Standards, Tenn. Water Quality Control Board Chapter 1200-4-5

Tennessee Air Quality Act, Tenn. Code Ann., Title 68, Chapter 25

Tennessee Air Pollution Control Regulations, Tenn. Dept. of Public Health, Chapters 1200-3-1 through 1200-3-22

Tennessee Safe Drinking Water Act, Tenn. Code Ann., Title 68, Chapter 13, Part 7

Standards for Protection Against Radiation, Tenn. Dept. of Public Health Rules, Chapter 1200-2-5 


\section{REMOVAL ACTION TECHNOLOGIES}

Alternative removal actions were identified by considering relevant technologies that could be implemented. The procedure and rationale for considering alternatives are consistent with the NCP and with EPA guidance regarding removal actions. The selected removal action alternative will provide a solution for the site and, consistent with the goals of the FUSRAP, real property will be certified to the extent practicable for use without radiological restrictions.

Section 121 of the Superfund Amendments and Reauthorization Act of 1986 (SARA) identifies a strong statutory preference for remedies that are highly reliable and provide longterm protection. The principal requirements for a selected remedy are that it be both protective of human health and the environment and cost-effective. Because the Elza Gate site is radioactively contaminated, the number of practicable and suitable treatment technologies that can be applied is limited. The technologies considered in selecting response action alternatives include those identified in the NCP (U.S. EPA 1990). Additional technologies addressed in the following discussion are based on experience and information gained as a result of remedial action planning and implementation at other sites. General response actions that are potentially applicable to the proposed action at the Elza Gate site include waste removal, waste reprocessing/treatment, storage, and disposal. Potentially applicable response actions and technologies are summarized in Table 7.

\subsection{REMOVAL}

The removal of contaminated materials may involve decontamination, demolition, and excavation. These technologies are reliable, can be easily implemented with standard construction equipment, and have been used extensively to control radioactive contamination similar to that associated with the Elza Gate site. Because the scope of the proposed action is limited to the cleanup of contaminated soil and concrete pads at the site, demolition and excavation are applicable removal technologies for the remaining cleanup.

\subsection{ACCESS RESTRICTIONS}

Access restrictions involve the use of physical barriers (e.g., fences) and institutional controls (e.g., deed restrictions or condemnation of property) to reduce the potential for public exposure to contaminated materials. The placement of physical barriers is relatively easy to implement and could protect human health and the environment. Physical barriers are typically not effective in controlling the source or migration of contaminants for extended periods. However, they can be effective when used to support other response actions (e.g., erecting access control barriers during excavation). Therefore, physical barriers as a sole response action will not be considered, but physical barriers will be retained as a potential technology to support other response actions.

Institutional controls are not generally effective in controlling the source or migration of contaminants for extended periods. Also, public concerns (e.g., exposure of site personnel and visitors, and inconvenience to property owners) could result in difficulties regarding their implementation. Therefore, institutional controls as an access restriction are eliminated from further consideration. 


\begin{tabular}{cccc}
$\begin{array}{c}\text { Technology } \\
\text { Type }\end{array}$ & $\begin{array}{c}\text { Type of } \\
\text { Contamination }\end{array}$ & $\begin{array}{c}\text { Evaluation } \\
\text { Result }\end{array}$ & Comments \\
\hline
\end{tabular}

\section{Access Restrictions}

\section{Physical barriers}

Institutional controls

In Situ Containment

Removal

Excavation

Decontamination

Demolition

Reprocessing/Retreatment

\section{Chemical treatment}

Leaching/extraction
Soils, sludges, structures, surface water, groundwater

Soils, sludges, structures, surface water, groundwater

Soils, sludges, surface water, groundwater

Soils, bulk wastes

Retained

Structural surfaces

Buildings, structures

Retained

Soils, bulk wastes, sludges

Retained

Rejected

Rejected of the Elza Gate site make this option impractical.

Reduces exposure to radioactive contaminants by reducing waste mobility and/or volume; allows unrestricted use of decontaminated area. Requires storage or disposal facility and access restrictions during excavation. Excavation is applicable to the proposed action at the Elza Gate site, which involves removal of contaminated materials.

Decontamination may be an applicable technology for portions of the concrete pads. Implementation is relatively straightforward.

Demolition can be implemented with standard equipment. It is applicable to the Elza Gate site because the contaminated concrete pads can be broken up and segregated, and contaminated rubble can be treated as contaminated waste.

Because of the large volume of soil and the heterogeneity of the contaminated materials (soil and concrete), leaching/extraction technologies are not considered cost-effective. Availability of a nearby disposal site at DOE's ORR also makes this technology less attractive. 


\section{TABLE 7 (Cont'd)}

\begin{tabular}{|c|c|c|c|}
\hline $\begin{array}{c}\text { Technology } \\
\text { Type }\end{array}$ & $\begin{array}{c}\text { Type of } \\
\text { Contamination }\end{array}$ & $\begin{array}{c}\text { Evaluation } \\
\text { Result }\end{array}$ & Comments \\
\hline
\end{tabular}

Physical treatment

\section{Dewatering}

Solids separation

Vitrification

Incineration

Sand sifting

Paramagnetic separation soil sorting, selective mineral separation
Saturated solids

Saturated solids

Rejected

Soil containing PCBs at greater than 50 ppm

Rejected
May reduce mobility or volume of waste constituents; allows unrestricted use of treated area. Requires treatment facility and access restrictions during treatment. Not applicable to the Elza Gate site because the contaminated materials are located above the water table.

Solids separation processes can limit the toxicity, mobility, and volume of contaminated materials and mitigate potential exposures, migration, and bioaccumulation. Although certain solids separation processes have been used to extract radionuclides from ores, they are generally ineffective for separating relatively low concentrations of contaminants from soil/sludge.

Rejected Not applicable at the Elza Gate site because of the nature of the contamination (i.e., not suitable for soil with high clay content and high water table); would not meet the overall objective of certifying the properties for use without radiological restrictions.

Incineration is generally used for material containing greater than $500 \mathrm{ppm}$ PCBs and is not technically or cost-effective for less contaminated soils, such as those present at the Elza Gate site.

Not applicable at the Elza Gate site because of the nature of the contamination (i.e., separation of low levels of contaminants from relatively large volumes of soil would involve unacceptable cost, time, technical, and institutional factors).

Not applicable at the Elza Gate site because of the nature of the contamination (i.e., separation of low levels of contaminants from relatively large volumes of soil would involve unacceptable cost, time, technical, and institutional factors) 
TABLE 7 (Cont'd)

\begin{tabular}{cccc}
\hline $\begin{array}{c}\text { Technology } \\
\text { Type }\end{array}$ & $\begin{array}{c}\text { Type of } \\
\text { Contamination }\end{array}$ & $\begin{array}{c}\text { Evaluation } \\
\text { Result }\end{array}$ & Comments \\
\hline
\end{tabular}

Storage

On-site

Soils, sludges, bulk Retained

wastes, liquids

Reduces waste mobility and exposure to radioactive and chemical contaminants. Requires the engineering of a storage facility and may be implemented as an interim measure while a permanent remedy is developed. Because of the small size of the site, private ownership of the site $e_{s}$ and the availability of a disposal facility at DOE's ORR less than $16 \mathrm{~km}(10 \mathrm{mi})$ from the site, on-site storage may be used only temporarily and as a staging area operation.

Off-site

Soils, sludges, bulk wastes

Retained

Storage or disposal facilities at DOE's ORR are available for radioactively contaminated materials, and non-hazardous wastes containing less than $50 \mathrm{ppm}$ PCBs. Wastes containing greater than 50 ppm PCBs could be disposed of at a TSCA-approved facility.

Disposal

On-site

Soils, sludges, bulk wastes, liquids

Rejected

Reduces waste mobility and exposure to radioactive and chemical contaminants Limits future land use; requires access restrictions for long term. Rejected because the Elza Gate site lacks appropriate facilities for on-site disposal and is privately owned. A storage or disposal site is available at DOE's nearby ORR.

Off-site

Soils, sludges, bulk wastes, liquids
Retained

Reduces waste mobility and exposure to radioactive and chemical contaminants; allows unrestricted use of decontaminated areas. DOE's ORR is a disposal facility that is less than $16 \mathrm{~km}$ (10 mi) from the Elza Gate site and provides a cost-effective disposal option for this removal action.

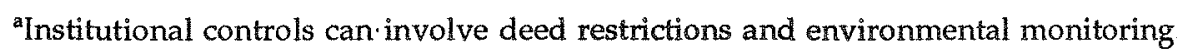




\subsection{IN SITU CONTAINMENT}

In situ containment involves the use of surface controls/diversions (e.g., swales and berms), capping (e.g., clay, asphalt, and geomembrane), and lateral barriers (e.g., slurry wall and grout curtain). In situ containment controls are relatively easy to implement and could protect human health and the environment by limiting contaminant mobility and reducing the potential for exposures. However, because of the characteristics of the site (e.g., sloping terrain, proximity to large bodies of surface water, and relatively high water table), the potential for horizontal migration of contaminants still exists. Therefore, in situ controls as a sole response will not be considered.

\subsection{REPROCESSING/TREATMENT}

Reprocessing/treatment includes a wide range of technologies, only a limited number of which can be implemented where radioactive contamination is present. (Incineration is possible with PCB-contaminated soil but is not a technically suitable or cost-effective treatment for low volumes of waste contaminated with less than 500 ppm of PCBs. Radioactive waste reprocessing/treatment technologies can be divided into two general categories:

- Those that remove the radioactive material from the waste matrix; and

- Those that change the form of the waste, thereby reducing its toxicity, mobility, or volume.

Treatment technologies include extraction, which involves separating radioactive and chemical contaminants from the waste matrix, and vitrification. The reprocessing/treatment of contaminated materials from the Elza Gate site was eliminated from further consideration because the radioactive and chemical materials in the soil are present in relatively low concentrations, thereby making separation by any developmental reprocessing or treatment technology difficult, time consuming, and costly. Similarly, no cost-effective and efficient treatment technology is available for decontamination of the concrete pads, which have numerous cracks and joints into which contaminants may have seeped.

\subsection{INTERIM STORAGE}

Interim storage involves the placement of contaminated materials in a manner that protects human health and the environment by limiting contaminant mobility and reducing the potential for exposure. This option requires the engineering of a storage facility and is implemented as an interim measure while a permanent remedy is developed. An interim storage facility can be implemented with standard construction procedures and conventional equipment. Interim storage can be achieved by placing the material in either an on-site or offsite facility. Both on-site interim storage and off-site storage at existing ORR waste storage areas will be retained for further consideration. Transportation of the wastes to ORR is discussed in Sec. 3.6. 


\subsection{TRANSPORTATION AND DISPOSAL}

Radioactively and chemically contaminated soil can be transported cost effectively by truck or rail. Wastes from previous remedial action activities at the Elza Gate site are being stored on-site. Because of the availability of a storage or disposal site for radioactive and nonhazardous chemical materials at DOE's ORR less than $16 \mathrm{~km}(10 \mathrm{mi})$ from the site, truck transport offers an efficient and cost-effective removal system. Haul trucks are lined with plastic before loading to prevent free water or dirt from escaping. To prevent soil from falling or blowing out of the truck, contaminated materials are covered by folding the plastic liners over the top of the materials or by placing another liner on top. Alternatively, the contaminated soil may be packaged in LSA boxes and then transported by truck. The waste containing greater than $50 \mathrm{ppm}$ PCBs can be packaged in special (17C) 55-gallon (gal) drums before being transported by truck to a disposal facility meeting TSCA requirements.

Disposal involves the placement of contaminated materials in a confined environment for permanent containment. This can be an effective means of reducing waste mobility and the associated potential for population exposure. The Elza Gate site lacks facilities for on-site disposal, but it is very close to DOE's ORR, which has been used for disposal of radioactive wastes in the past. The ORR has several disposal areas that require additional fill material to complete the cap for closure. Inclusion of the Elza Gate materials would aid in closure by providing needed fill and would not contribute appreciably to the total contaminant levels of the wastes. In addition, the contamination at the Elza Gate site is the result of materials that were used at the ORR. Thus, transportation of the untreated soil from the Elza Gate site and subsequent disposal at DOE's ORR is a reasonable alternative.

\subsection{IDENTIFICATION OF PRELIMINARY REMOVAL ACTION ALTERNATIVES}

Alternatives for the proposed removal action were identified on the basis of applicable technologies consistent with the criteria set forth in the NCP. The potential technologies described in Secs. 3.1 through 3.6 and summarized in Table 7 were screened with regard to implementability, on the basis of characteristics of the Elza Gate site and the waste materials at this property. No treatment technology has yet been accepted, in terms of effectiveness and reliability, that would either eliminate the risks associated with radioactive contaminants or neutralize the radioactivity of the materials. Therefore, on the basis of the nature of the contamination at the Elza Gate site and on the unavailability of an acceptable technology, the treatment option was eliminated during the preliminary screening. In addition, treatment technologies are not included as components of any of the proposed alternatives.

The preliminary screening of potentially applicable technologies, as summarized in Table 7, resulted in identification of the following technologies as potential components of removal action alternatives: access restrictions (physical barriers), removal (excavation, decontamination, and demolition), storage, and disposal. The screened technologies have been grouped into preliminary alternatives for the proposed action as follows:

Alternative 1: No action;

Alternative 2: On-site interim storage of radioactive and nonhazardous chemically contaminated material. Soils contaminated with PCBs at concentrations in excess of $50 \mathrm{ppm}$ would be disposed 
of at a commercial, licensed TSCA disposal site. This alternative includes temporary access restrictions during removal activities.

Alternative 3: Removal of contaminated materials from the site, with off-site storage or disposal of radioactive and nonhazardous chemically contaminated material at the ORR. Soils contaminated with PCBs at concentrations in excess of $50 \mathrm{ppm}$ would be disposed of at a commercial, licensed TSCA disposal site. This alternative includes temporary access restrictions during removal activities. 


\section{ANALYSIS OF ALTERNATIVES}

Potential removal action alternatives for the proposed action were screened with regard to applicability and institutional considerations, on the basis of characteristics of the Elza Gate site and the waste materials present. A no-action alternative (Alternative 1) was retained. Excavation and interim storage on the Elza Gate site was also retained as an alternative (Alternative 2). Under this alternative, radioactive materials exceeding guidelines, soils containing PCBs at concentrations below $50 \mathrm{ppm}$, and soils containing lead at greater than $1000 \mathrm{ppm}$ would be excavated and encapsulated in a cell for interim storage until a permanent disposal option becomes available. Soils containing PCBs at concentrations of greater than $50 \mathrm{ppm}$ would be disposed of off-site at a commercial, licensed TSCA disposal facility. The option for disposal or interim storage on the ORR (Alternative 3) was retained. Under this alternative, radioactive materials, soils containing PCBs at concentrations below $50 \mathrm{ppm}$ and soils containing lead at greater than $1000 \mathrm{ppm}$ would be disposed of or put into interim storage on the ORR. Soils containing PCBs at concentrations above $50 \mathrm{ppm}$ would be disposed of off-site at a commercial licensed TSCA disposal facility. An analysis of these removal action alternatives is provided in Secs. 4.1 through 4.3 .

\subsection{ALTERNATIVE 1: NO-ACTION}

As governed by CERCLA, a no-action alternative must be considered to provide a baseline for comparison with other alternatives. Under this alternative, the DOE cannot apply access restrictions (physical barriers and institutional controls) to minimize exposure of the general public to the radioactively and chemically contaminated materials at the site because the site is privately owned. In any case, access restrictions are not effective against environmental factors such as wind, rain, or snow. Also, such restrictions require monitoring and maintenance and are generally ineffective and unreliable in the long term. The potential for human exposure to radioactive and chemical contaminants and the potential for off-site migration of these materials would continue to exist in the short and the long term. Furthermore, modification of the property cannot be foreclosed when it is sold or leased. Thus, in the absence of long-term restrictions regarding use of the land at the Elza Gate site, uncontrolled releases of contaminated materials could occur through off-site migration of contaminants or redevelopment of the property in the future. As a result, this alternative is rejected from the outset as not being adequately protective of human health and welfare and the environment.

\subsection{ALTERNATIVE 2: ON-SITE STORAGE AT THE ELZA GATE SITE}

Under this alternative, radiologically and chemically contaminated soils (i.e., soils with PCB concentrations between 25 and $50 \mathrm{ppm}$ or lead levels greater than $1000 \mathrm{ppm}$ ) would be excavated and placed in a sealed membrane, on-site, for interim storage. The PCB-contaminated soil with concentrations exceeding $50 \mathrm{ppm}$ would be disposed of at a commercial facility meeting TSCA requirements. At such time as a disposal site could be identified and agreements made to utilize it, the encapsulated wastes would be transported there for permanent disposition.

This alternative is rejected without further discussion principally because the DOE wishes to institute a solution that will be as fully protective of human health and welfare and the environment as possible. Short-term storage of wastes on a site intended for commercial 
business will result in the potential for unnecessary exposure of employees of the sites businesses and of visitors to the site. The potential for release of materials back into the environment through incidents involving weather, vandalism, or failure of the capsule cannot be foreclosed.

\subsection{ALTERNATIVE 3: REMOVAL TO THE OAK RIDGE RESERVATION}

This alternative would provide for excavation and disposition of soil and rubble contaminated with radionuclides, as well as soil contaminated with PCBs and lead, from the entire Elza Gate site. The purpose of Alternative 3 is to safely remove, transport, and store on an interim basis or dispose of these materials at DOE's ORR. Wastes containing between 25 and $50 \mathrm{ppm}$ PCBs and not categorized as hazardous under RCRA regulations would also be stored or disposed of at the ORR. The $670-\mathrm{m}^{3}\left(875-\mathrm{yd}^{3}\right)$ volume of waste that exceeds the $50 \mathrm{ppm}$ criteria for PCBs would be transported to a TSCA-regulated facility. The exact removal option on the ORR would be decided before the removal action commences, that is, either disposal on the Waste Area Grouping 6 site, disposal on the United Nuclear Corporation site on Chestnut Ridge on the Y-12 Plant, interim storage on the East Central Chestnut Ridge site, or interim storage on the Solid Waste Storage Area 7X (SWSA 7X). All four sites would serve to remove the Elza Gate wastes from an area accessible to the public, where security and maintenance are difficult, to a controlled area already containing hazardous wastes. In the interest of moving the wastes within the 1991 construction season, negotiations for the exact disposition site are proceeding while the proposal is offered for comment. This removal action alternative has been evaluated in terms of its protectiveness of public health and the environment, timeliness, technical feasibility, effectiveness, and cost considerations.

\subsubsection{Protection of Public Health and the Environment}

The effectiveness of an alternative is defined by its effectiveness in ensuring the protection of and minimizing adverse effects on human health and the environment. For the proposed removal action, contaminated soil and rubble would be excavated, transported, and stored or disposed of at DOE's ORR. Excavation would disturb the contaminated materials, which might temporarily result in increased radioactive and chemical releases. However, mitigative measures would be implemented during the action period to minimize potential releases of particulates and waste water, and all response actions would be implemented in accordance with federal and state regulatory requirements.

To assess both radiological and chemical impacts associated with the proposed removal action, the potential radiation doses and chemical intakes were estimated for removal action workers. Only those workers implementing the removal action would be exposed because the site is an industrial property and access control and barriers would be used in the vicinity of the work area. Potential radiation doses and chemical intakes for workers performing the removal action would be kept as low as reasonably achievable. Control of exposures to the workers would be sufficiently stringent that releases of contaminants at levels that could significantly expose workers in the on-site business or any person off-site would not occur.

The primary pathway by which workers could incur radiation doses would be through external exposure, principally to radium-226 and its decay products. This risk would be controlled by limiting proximity and exposure times near the wastes. Inhalation of airborne 
radioactive and chemical contaminants generated during excavation and waste handling and dermal absorption of PCBs could also be significant potential exposure pathways if not controlled. Based on the average radon flux measurements at the site, the dose that could be received from exposure to above-background radon is considered to be minimal and therefore not included in this assessment. The dose to workers would be minimized and exposure of employees of an on-site business and of all off-site persons would be prevented by using procedures to control the amount of airborne contamination (e.g., dust control by spraying water). To the extent possible, removal efforts would be conducted during nonbusiness hours. Workers would wear respiratory protection equipment and protective clothing, as required, to reduce the likelihood of inhaling contaminated particulates or of dermal absorption of contaminants. Workers would also wear lapel monitors that would be analyzed daily to verify the safety of the working environment with respect to radiological contaminants. Air monitors would be used at the perimeter of the work area for the calculation and control of airborne releases. Workers would be trained with regard to radiation and chemical risks and proper hazardous materials procedures. In all cases, adherence to standard health and safety practices, compliance with DOE environmental protection, safety, and health protection guidelines (DOE Order 5400.5, DOE Order 5480.11, DOE Order 5820.2A), and compliance with any other applicable federal and state statutes would be maintained to assure safety in the work environment and to keep exposures for all persons as low as reasonably achievable.

It is estimated that 14 workers and 4500 worker-hours would be required to implement all phases of the proposed removal action (e.g., planning, startup, excavation, transportation, shutdown [Poligone 1990b]) at the Elza Gate site. A separate crew would be used at the ORR for placement of excavated materials. As many as 9 workers would be directly involved in the actual removal activities at the Elza Gate site, for a total exposure period of 1628 worker-hours. It is assumed that another 9 workers would be exposed on the ORR in receiving and encapsulating the wastes, for a total of another 1628 worker-hours. Additionally, three truckers working for a total period of 122 hours are assumed to be required to transport the wastes.

For radiological external exposure and inhalation dose estimates for the excavation and loading phase on the Elza Gate site, a special code was used (Gilbert et al. 1989). The code was developed by DOE for residual radioactive (RESRAD) material dose calculations and is specified in DOE Order 5400.5 (U.S. DOE 1990b). Except for radionuclide concentrations, waste areas, depths and thicknesses, and exposure periods, all input values were those used in deriving the uranium guidelines for this site (Cheng et al. 1991).

Measured soil values consisted of data for uranium-238, radium-226, thorium- 230 and thorium-232. It was assumed that the uranium-234 concentration equaled that of uranium-238, that the uranium-235 concentration was $5 \%$ of the uranium-238 concentration (as occurs naturally), and that the protactinium-231 and actinium-227 concentrations were $10 \%$ of the uranium-238 concentration (twice normal). The latter two were added on the basis of experience showing that these radionuclides can contribute significantly to the inhalation dose. The $10 \%$ level assumed that some concentration of protactinium-231 and actinium-227 had occurred during uranium processing but that some dilution had also occurred when tailings were commingled with site soils. (For this removal action, as will be shown below, inhalation dose estimates showed that $45 \%$ of the inhalation dose arose from actinium- 227 and $9 \%$ from protactinium-231, thus justifying their inclusion.) No allowances were made for respiratory protection in these calculations, and dust-control activities during the removal action could substantially lower inhalation doses. 
The site was divided into 17 areas for the purpose of dose calculations for external exposure and inhalation (see Fig. 7). Measured concentrations of uranium-238, radium-226, thorium-232, and thorium-230 by area are presented in Table 8 . Doses were calculated for the top layer $(0-0.9 \mathrm{~m}[0-3 \mathrm{ft}])$ unless data were available for a shallower layer, and a lower layer

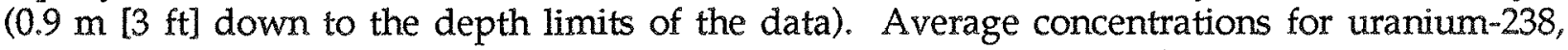
radium-226, thorium-232 and thorium-230 were assigned to each layer. From these, the estimated concentrations of uranium-234, uranium-235, protactinium-231, and actinium-227 for each layer were added in.

For the waste reception area on the ORR, it was assumed the same total dose would be incurred by these workers in dumping, distributing, surveying, and encapsulating the wastes as was incurred by the Elza Gate workforce in excavating, loading, and surveying the wastes. Nine workers were assumed for the reception area activities.

The results of the RESRAD dose calculations are presented in Tables 9 through 11. The estimated individual worker doses from external exposure and inhalation during the removal action would range from less than 1 mrem to about 66 mrem in the 17 cleanup areas. Collective doses for these areas would range from less than $1 \mathrm{mrem}$ to about $608 \mathrm{mrem}$, almost totally due to Area 2 (Table 12). The risk of cancer incidence for the total collective dose would be about $3.6 \times 10^{-4}$ on the basis of EPA risk factors (U.S. EPA 1989d).

Doses to truckers moving the wastes from the Elza Gate site to the ORR were calculated by assuming that external exposure doses originated principally from radium-226 plus decay products in Area 2 wastes (see Fig. 7). RESRAD calculations substantiate this assumption. The truck was not assumed to provide any shielding for the driver, and the source was taken as a flat source of infinite extent. The conservative dose estimate for truckers moving the waste from Area 2 to the ORR is about $85 \mathrm{mrem}$, each with a collective dose of about $255 \mathrm{mrem}$ (see Táble 12). A small increment would be added to this by movement from the other 16 areas. Actual doses are anticipated to be lower because the waste would have limited dimensions and the truck would provide shielding. The cancer incidence risk would be about $1.5 \times 10^{-4}$ for the collective dose to the truck drivers (U.S. EPA 1989d).

The estimated average dose to each of the nine workers on the ORR would be about 68 mrem for the entire waste disposal/storage activity, again substantially due to external exposure from radium-226 and its decay products (Table 12). The cancer incidence risk would be about $3.6 \times 10^{-4}$ for the total collective dose for workers on the ORR.

Overall, doses to individual workers are estimated to be well below the stochastic effects limit of $5000 \mathrm{mrem} / \mathrm{yr}$ that is set forth in DOE Order 5480.11 (U.S. DOE 1988) and presidential guidance for federal agencies (U.S. EPA 1987a). Approximately $98 \%$ of the total Elza Gate site dose would be from exposure to external gamma radiation in Area 2. Of the total project dose, approximately $41 \%$ is incurred at Elza Gate, $17 \%$ in trucking, and $41 \%$ at ORR (see Table 12).

The potential chemical intake was estimated using EPA methodology (U.S. EPA 1989a) and was compared with permissible exposure levels (PELs) promulgated by the U.S. Department of Labor (1989). For potential chemical carcinogens, a carcinogenic risk was also calculated. The carcinogenic risk associated with dermal absorption of PCBs was evaluated separately. 


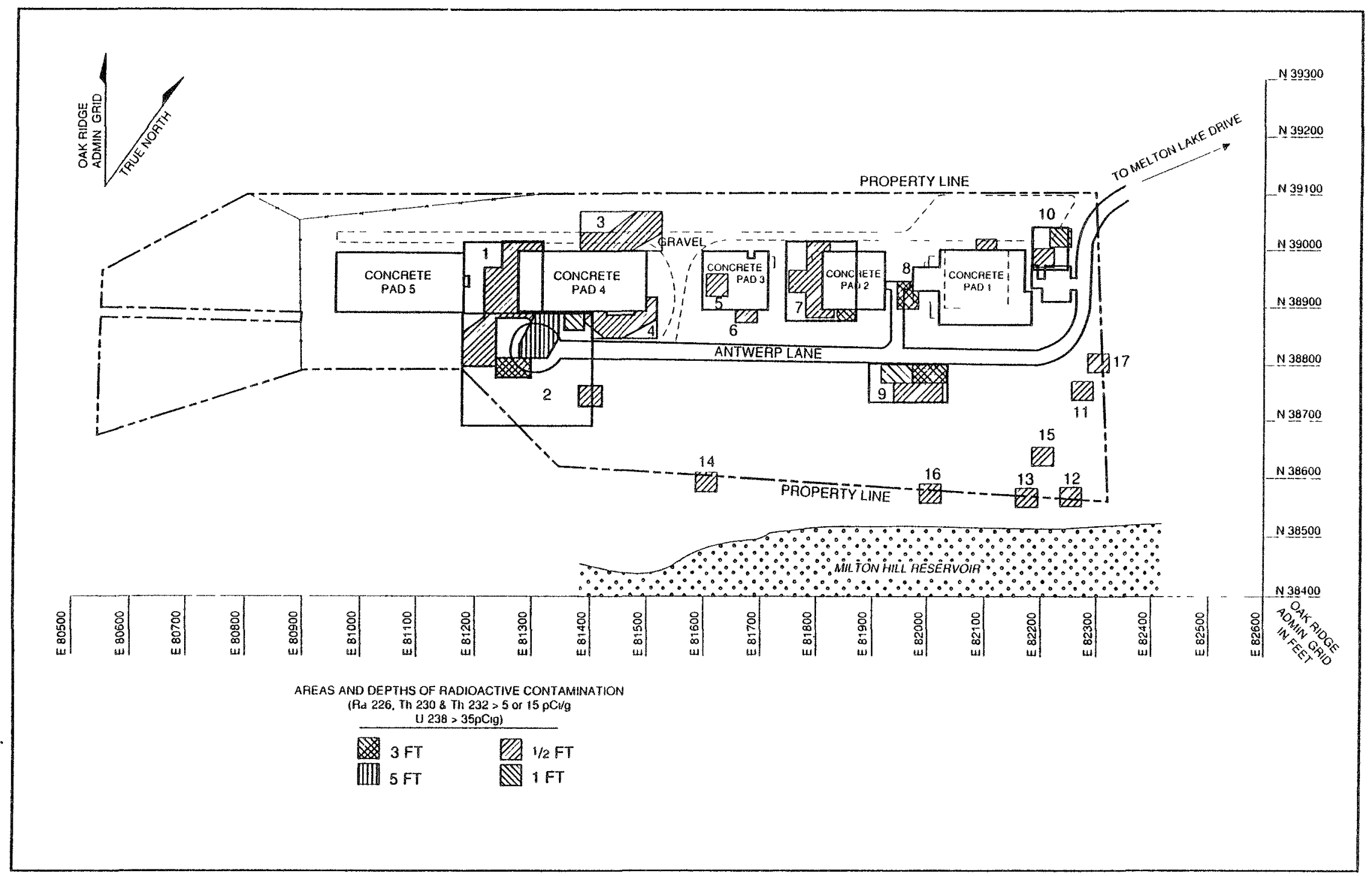

FIGURE 7 Areas for Calculation of Doses with RESRAD Code 
TABLE 8 Input Variables for RESRAD Code Dose Calculations

\begin{tabular}{|c|c|c|c|c|c|c|c|c|}
\hline \multirow[b]{2}{*}{ Area } & \multirow{2}{*}{$\begin{array}{l}\text { Depth } \\
(\mathrm{ft})\end{array}$} & \multicolumn{4}{|c|}{ Soil Constituent $(\mathrm{pCi} / \mathrm{g})$} & \multirow{2}{*}{$\begin{array}{l}\text { Area } \\
\left(\mathrm{m}^{2}\right)\end{array}$} & \multirow{2}{*}{$\frac{\begin{array}{c}\text { Cleanup } \\
\text { Time }\end{array}}{\text { (h) }}$} & \multirow{2}{*}{$\begin{array}{c}\text { Number } \\
\text { of } \\
\text { Workers }\end{array}$} \\
\hline & & $\mathrm{U}-238$ & $\operatorname{Ra}-226$ & Th-232 & Th-230 & & & \\
\hline \multirow[t]{2}{*}{1} & $0-3$ & 3.0 & 0.4 & 0.0 & 0.9 & 930 & 16 & 9 \\
\hline & $3-4$ & 1 & 0 & 0.2 & 0 & & & \\
\hline \multirow[t]{2}{*}{2} & $0-3$ & 385.6 & 405.9 & 2.2 & 506.2 & 4000 & 80 & 9 \\
\hline & $3-7$ & 8.8 & 2.4 & 0.3 & 7.4 & & & \\
\hline \multirow[t]{2}{*}{3} & $0-3$ & 2.8 & 0 & 0 & 3.5 & 1400 & 24 & 9 \\
\hline & $3-4$ & 1.5 & 0 & 0 & 0 & & & \\
\hline \multirow[t]{2}{*}{4} & $0-3$ & 3.8 & 2.6 & 0 & 4 & 500 & 16 & 9 \\
\hline & $3-8$ & 0.3 & 0 & 0 & 0.3 & & & \\
\hline 5 & $0-2.5$ & 4.5 & 0 & 0 & 14.5 & 1 & 1 & 4 \\
\hline \multirow[t]{2}{*}{6} & $0-3$ & 6.5 & 0.4 & 0 & 2.5 & 1 & 1 & 4 \\
\hline & $3-4$ & 2 & 0 & 0 & 0.3 & & & \\
\hline \multirow[t]{2}{*}{7} & $0-3$ & 9.5 & 30.3 & 0 & 34.6 & 1100 & 16 & 9 \\
\hline & $3-6$ & 2 & 0.4 & 0 & 3.4 & & & \\
\hline 8 & $0-1$ & 12.8 & 21.2 & 1.7 & 98.3 & 3 & 2 & 4 \\
\hline \multirow[t]{2}{*}{9} & $0-3$ & 13.4 & 15.5 & 0.1 & 25.4 & 560 & 16 & 9 \\
\hline & $3-6$ & 2.4 & 0.2 & 0.1 & 2.1 & & & \\
\hline \multirow[t]{2}{*}{10} & $0-3$ & 2.8 & 4.2 & 0 & 1.9 & 110 & 8 & 9 \\
\hline & $3-5$ & 1 & 0 & 0.3 & 0 & & & \\
\hline 11 & $0-0.5$ & 6 & 0 & 5.4 & 3.7 & 1 & 1 & 4 \\
\hline 12 & $0-0.5$ & 0 & 0 & 0.4 & 8 & 1 & 1 & 4 \\
\hline 13 & $0-0.5$ & 5 & 0 & 0 & 5.2 & 1 & 1 & 4 \\
\hline 14 & $0-0.5$ & 5 & 1.6 & 0 & 50.8 & 1 & 1 & 4 \\
\hline 15 & $0-1.5$ & 1.7 & 0.2 & 0 & 1.4 & 1 & 1 & 4 \\
\hline \multirow[t]{2}{*}{16} & $0-3$ & 4.4 & 0.1 & 0.7 & 1.3 & 1 & 1 & 4 \\
\hline & $3-4$ & 5 & 0 & 0 & 0.8 & & & \\
\hline 17 & $0-0.5$ & 6 & 1.3 & 1.4 & 1.7 & 1 & 1 & 4 \\
\hline
\end{tabular}


TABLE 9 Summary of Estimated External Exposure Doses by Area (external exposure doses based on sum of all depths [mrem])

\begin{tabular}{|c|c|c|c|c|c|c|c|c|c|c|}
\hline Area & $A c-227$ & $\mathrm{~Pa}-231$ & $\mathrm{Ra}-226$ & Th-230 & Th-232 & U-234 & U-235 & U-238 & $\begin{array}{l}\text { Dose } \\
\text { by Area }\end{array}$ & Percent \\
\hline 1 & $<0.1$ & $<0.1$ & $<0.1$ & $<0.1$ & $<0.1$ & $<0.1$ & $<0.1$ & $<0.1$ & 0.0 & 0.0 \\
\hline 2 & 0.9 & 0.1 & 56.3 & $<0.1$ & $<0.1$ & $<0.1$ & 0.2 & 0.4 & 57.9 & 97.7 \\
\hline 3 & $<0.1$ & $<0.1$ & $<0.1$ & $<0.1$ & $<0.1$ & $<0.1$ & $<0.1$ & $<0.1$ & 0.0 & 0.0 \\
\hline 4 & $<0.1$ & $<0.1$ & 0.1 & $<0.1$ & $<0.1$ & $<0.1$ & $<0.1$ & $<0.1$ & 0.1 & 0.1 \\
\hline 5 & $<0.1$ & $<0.1$ & $<0.1$ & $<0.1$ & $<0.1$ & $<0.1$ & $<0.1$ & $<0.1$ & 0.0 & 0.0 \\
\hline 6 & $<0.1$ & $<0.1$ & $<0.1$ & $<0.1$ & $<0.1$ & $<0.1$ & $<0.1$ & $<0.1$ & 0.0 & 0.0 \\
\hline 7 & $<0.1$ & $<0.1$ & 0.9 & $<0.1$ & $<0.1$ & $<0.1$ & $<0.1$ & $<0.1$ & 0.9 & 1.5 \\
\hline 8 & $<0.1$ & $<0.1$ & $<0.1$ & $<0.1$ & $<0.1$ & $<0.1$ & $<0.1$ & $<0.1$ & 0.0 & 0.0 \\
\hline 9 & $<0.1$ & $<0.1$ & 0.4 & $<0.1$ & $<0.1$ & $<0.1$ & $<0.1$ & $<0.1$ & 0.4 & 0.7 \\
\hline 10 & $<0.1$ & $<0.1$ & $<0.1$ & $<0.1$ & $<0.1$ & $<0.1$ & $<0.1$ & $<0.1$ & 0.0 & 0.0 \\
\hline 11 & $<0.1$ & $<0.1$ & $<0.1$ & $<0.1$ & $<0.1$ & $<0.1$ & $<0.1$ & $<0.1$ & 0.0 & 0.0 \\
\hline 12 & $<0.1$ & $<0.1$ & $<0.1$ & $<0.1$ & $<0.1$ & $<0.1$ & $<0.1$ & $<0.1$ & 0.0 & 0.0 \\
\hline 13 & $<0.1$ & $<0.1$ & $<0.1$ & $<0.1$ & $<0.1$ & $<0.1$ & $<0.1$ & $<0.1$ & 0.0 & 0.0 \\
\hline 14 & $<0.1$ & $<0.1$ & $<0.1$ & $<0.1$ & $<0.1$ & $<0.1$ & $<0.1$ & $<0.1$ & 0.0 & 0.0 \\
\hline 15 & $<0.1$ & $<0.1$ & $<0.1$ & $<0.1$ & $<0.1$ & $<0.1$ & $<0.1$ & $<0.1$ & 0.0 & 0.0 \\
\hline 16 & $<0.1$ & $<0.1$ & $<0.1$ & $<0.1$ & $<0.1$ & $<0.1$ & $<0.1$ & $<0.1$ & 0.0 & 0.0 \\
\hline 17 & $<0.1$ & $<0.1$ & $<0.1$ & $<0.1$ & $<0.1$ & $<0.1$ & $<0.1$ & $<0.1$ & 0.0 & 0.0 \\
\hline Sums by nuclide & 0.9 & 0.1 & 57.7 & 0.0 & 0.0 & 0.0 & 0.2 & 0.4 & 59.3 & \\
\hline $\begin{array}{l}\text { Percent of external } \\
\text { exposure dose }\end{array}$ & 1.6 & 0.1 & 97.3 & 0.0 & 0.0 & 0.0 & 0.3 & 0.7 & 100.0 & \\
\hline
\end{tabular}


TABLE 10 Summary of Estimated Inhalation Doses by Area (inhalation doses based on top layer Imrem])

\begin{tabular}{|c|c|c|c|c|c|c|c|c|c|c|}
\hline Area & Ac- 227 & $\mathrm{~Pa}-231$ & $\mathrm{Ra}-226$ & Th-230 & Th-232 & U-234 & U-235 & U-238 & $\begin{array}{c}\text { Dose } \\
\text { by Area }\end{array}$ & Percent \\
\hline 1 & $<0.1$ & $<0.1$ & $<0.1$ & $<0.1$ & & $<0.1$ & $<0.1$ & $<0.1$ & 0.0 & 0.0 \\
\hline 2 & 3.7 & 0.7 & $<0.1$ & 2.3 & 0.1 & 0.7 & $<0.1$ & 0.7 & 8.2 & 100.0 \\
\hline 3 & $<0.1$ & $<0.1$ & & $<0.1$ & & $<0.1$ & $<0.1$ & $<0.1$ & 0.0 & 0.0 \\
\hline 4 & $<0.1$ & $<0.1$ & $<0.1$ & $<0.1$ & & $<0.1$ & $<0.1$ & $<0.1$ & 0.0 & 0.0 \\
\hline 5 & $<0.1$ & $<0.1$ & & $<0.1$ & & $<0.1$ & $<0.1$ & $<0.1$ & 0.0 & 0.0 \\
\hline 6 & $<0.1$ & $<0.1$ & $<0.1$ & $<0.1$ & & $<0.1$ & $<0.1$ & $<0.1$ & 0.0 & 0.0 \\
\hline 7 & $<0.1$ & $<0.1$ & $<0.1$ & $<0.1$ & & $<0.1$ & $<0.1$ & $<0.1$ & 0.0 & 0.0 \\
\hline 8 & $<0.1$ & $<0.1$ & $<0.1$ & $<0.1$ & $<0.1$ & $<0.1$ & $<0.1$ & $<0.1$ & 0.0 & 0.0 \\
\hline 9 & $<0.1$ & $<0.1$ & $<0.1$ & $<0.1$ & $<0.1$ & $<0.1$ & $<0.1$ & $<0.1$ & 0.0 & 0.0 \\
\hline 10 & $<0.1$ & $<0.1$ & $<0.1$ & $<0.1$ & & $<0.1$ & $<0.1$ & $<0.1$ & 0.0 & 0.0 \\
\hline 11 & $<0.1$ & $<0.1$ & & $<0.1$ & $<0.1$ & $<0.1$ & $<0.1$ & $<0.1$ & 0.0 & 0.0 \\
\hline 12 & & & & $<0.1$ & $<0.1$ & & & & 0.0 & 0.0 \\
\hline 13 & $<0.1$ & $<0.1$ & & $<0.1$ & & $<0.1$ & $<0.1$ & $<0.1$ & 0.0 & 0.0 \\
\hline 14 & $<0.1$ & $<0.1$ & $<0.1$ & $<0.1$ & & $<0.1$ & $<0.1$ & $<0.1$ & 0.0 & 0.0 \\
\hline 15 & $<0.1$ & $<0.1$ & & $<0.1$ & $<0.1$ & $<0.1$ & $<0.1$ & $<0.1$ & 0.0 & 0.0 \\
\hline 16 & $<0.1$ & $<0.1$ & $<0.1$ & $<0.1$ & $<0.1$ & $<0.1$ & $<0.1$ & $<0.1$ & 0.0 & 0.0 \\
\hline 17 & $<0.1$ & $<0.1$ & $<0.1$ & $<0.1$ & $<0.1$ & $<0.1$ & $<0.1$ & $<0.1$ & 0.0 & 0.0 \\
\hline Sums by nuclide & 3.7 & 0.7 & 0.0 & 2.3 & 0.1 & 0.7 & 0.0 & 0.7 & 8.2 & \\
\hline Percent of inhalation dose & 45.3 & 8.8 & 0.0 & 28.4 & 0.6 & 8.8 & 0.0 & 8.1 & 100.0 & \\
\hline
\end{tabular}


TABLE 11 Summary of Estimated Total Doses by Area (external exposure + inhalationl Imreml)

\begin{tabular}{|c|c|c|c|c|c|c|c|c|c|c|}
\hline Area & Ac- 227 & $\mathrm{~Pa}-231$ & $\mathrm{Ra}-226$ & Th-230 & Th-232 & U-234 & U-235 & $\mathrm{U}-238$ & $\begin{array}{c}\text { Dose } \\
\text { by Area }\end{array}$ & Percent \\
\hline 1 & $<0.1$ & $<0.1$ & $<0.1$ & $<0.1$ & $<0.1$ & $<0.1$ & $<0.1$ & $<0.1$ & 0.0 & 0.0 \\
\hline 2 & 4.7 & 0.8 & 56.3 & 2.3 & 0.1 & 0.7 & 0.2 & 1.1 & 66.1 & 98.0 \\
\hline 3 & $<0.1$ & $<0.1$ & $<0.1$ & $<0.1$ & $<0.1$ & $<0.1$ & $<0.1$ & $<0.1$ & 0.0 & 0.0 \\
\hline 4 & $<0.1$ & $<0.1$ & 0.1 & $<0.1$ & $<0.1$ & $<0.1$ & $<0.1$ & $<0.1$ & 0.1 & 0.1 \\
\hline 5 & $<0.1$ & $<0.1$ & $<0.1$ & $<0.1$ & $<0.1$ & $<0.1$ & $<0.1$ & $<0.1$ & 0.0 & 0.0 \\
\hline 6 & $<0.1$ & $<0.1$ & $<0.1$ & $<0.1$ & $<0.1$ & $<0.1$ & $<0.1$ & $<0.1$ & 0.0 & 0.0 \\
\hline 7 & $<0.1$ & $<0.1$ & 0.9 & $<0.1$ & $<0.1$ & $<0.1$ & $<0.1$ & $<0.1$ & 0.9 & 1.3 \\
\hline 8 & $<0.1$ & $<0.1$ & $<0.1$ & $<0.1$ & $<0.1$ & $<0.1$ & $<0.1$ & $<0.1$ & 0.0 & 0.0 \\
\hline 9 & $<0.1$ & $<0.1$ & 0.4 & $<0.1$ & $<0.1$ & $<0.1$ & $<0.1$ & $<0.1$ & 0.4 & 0.6 \\
\hline 10 & $<0.1$ & $<0.1$ & $<0.1$ & $<0.1$ & $<0.1$ & $<0.1$ & $<0.1$ & $<0.1$ & 0.0 & 0.0 \\
\hline 11 & $<0.1$ & $<0.1$ & $<0.1$ & $<0.1$ & $<0.1$ & $<0.1$ & $<0.1$ & $<0.1$ & 0.0 & 0.0 \\
\hline 12 & $<0.1$ & $<0.1$ & $<0.1$ & $<0.1$ & $<0.1$ & $<0.1$ & $<0.1$ & $<0.1$ & 0.0 & 0.0 \\
\hline 13 & $<0.1$ & $<0.1$ & $<0.1$ & $<0.1$ & $<0.1$ & $<0.1$ & $<0.1$ & $<0.1$ & 0.0 & 0.0 \\
\hline 14 & $<0.1$ & $<0.1$ & $<0.1$ & $<0.1$ & $<0.1$ & $<0.1$ & $<0.1$ & $<0.1$ & 0.0 & 0.0 \\
\hline 15 & $<0.1$ & $<0.1$ & $<0.1$ & $<0.1$ & $<0.1$ & $<0.1$ & $<0.1$ & $<0.1$ & 0.0 & 0.0 \\
\hline 16 & $<0.1$ & $<0.1$ & $<0.1$ & $<0.1$ & $<0.1$ & $<0.1$ & $<0.1$ & $<0.1$ & 0.0 & 0.0 \\
\hline 17 & $<0.1$ & $<0.1$ & $<0.1$ & $<0.1$ & $<0.1$ & $<0.1$ & $<0.1$ & $<0.1$ & 0.0 & 0.0 \\
\hline Sums by nuclide & 4.7 & 0.8 & 57.7 & 2.3 & 0.1 & 0.7 & 0.2 & 1.1 & 67.5 & \\
\hline Percent of total dose & 6.9 & 1.2 & 85.4 & 3.5 & 0.1 & 1.1 & 0.2 & 1.6 & 100.0 & \\
\hline
\end{tabular}


TABLE 12 Summary of Estimated Individual and Collective Doses by Area

\begin{tabular}{|c|c|c|c|c|c|}
\hline \multirow[b]{2}{*}{ Area } & \multirow{2}{*}{$\begin{array}{c}\text { Dose per } \\
\text { Worker } \\
\text { (mrem/job) }\end{array}$} & \multirow{2}{*}{$\begin{array}{c}\text { Exposure } \\
\text { Period } \\
\text { (h) }\end{array}$} & \multirow{2}{*}{$\begin{array}{l}\text { Workers } \\
\text { Exposed }\end{array}$} & \multicolumn{2}{|c|}{ Worker Collective Dose } \\
\hline & & & & mrem/job & Percent \\
\hline 1 & 0.0 & 16 & 9 & 0.0 & 0.0 \\
\hline 2 & 66.1 & 80 & 9 & 595.2 & 40.5 \\
\hline 3 & 0.0 & 24 & 9 & 0.0 & 0.0 \\
\hline 4 & 0.1 & 16 & 9 & 0.6 & 0.0 \\
\hline 5 & 0.0 & 1 & 4 & 0.0 & 0.0 \\
\hline 6 & 0.0 & 1 & 4 & 0.0 & 0.0 \\
\hline 7 & 0.9 & 16 & 9 & 8.2 & 0.6 \\
\hline 8 & 0.0 & 2 & 4 & 0.0 & 0.0 \\
\hline 9 & 0.4 & 16 & 9 & 3.5 & 0.2 \\
\hline 10 & 0.0 & 8 & 9 & 0.0 & 0.0 \\
\hline 11 & 0.0 & 1 & 4 & 0.0 & 0.0 \\
\hline 12 & 0.0 & 1 & 4 & 0.0 & 0.0 \\
\hline 13 & 0.0 & 1 & 4 & 0.0 & 0.0 \\
\hline 14 & 0.0 & 1 & 4 & 0.0 & 0.0 \\
\hline 15 & 0.0 & 1 & 4 & 0.0 & 0.0 \\
\hline 16 & 0.0 & 1 & 4 & 0.0 & 0.0 \\
\hline 17 & 0.0 & 1 & 4 & 0.0 & 0.0 \\
\hline $\begin{array}{l}\text { Sum of collective } \\
\text { dose }\end{array}$ & & & & 607.5 & 41.3 \\
\hline $\begin{array}{l}\text { Truckers hauling } \\
\text { to Area } 2\end{array}$ & 85 & 122 & 3 & 255.0 & 17.3 \\
\hline ORR waste area ${ }^{a}$ & 67.5 & 180.9 & 9 & 607.5 & 41.3 \\
\hline Sum & & & & 1470.0 & 100.0 \\
\hline
\end{tabular}

assumed 9 workers at reception area, for same 1628 man-hours it took to load wastes, with same total dose as for waste excavation and loading.

For the calculation of chemical intakes, the average and maximum soil concentrations

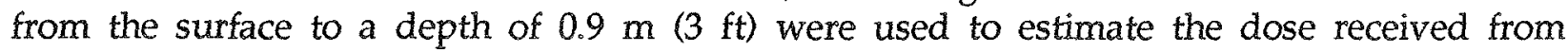
inhalation of chemicals resuspended from soil into air during excavation. A work duration of $200 \mathrm{~h} /$ worker and a concentration of dust in air of $0.2 \mathrm{mg} / \mathrm{m}^{3}$ were assumed. An inhalation rate of $1.2 \mathrm{~m}^{3} / \mathrm{h}$ was also assumed (U.S. EPA (1989c). The cumulative exposure of workers to PCBs and metals at the site was calculated to determine that the level did not exceed 1 under the procedure described by the U.S. Department of Labor (1989). A cumulative exposure of less than 1 indicates that toxicity is unlikely. The cumulative exposure via inhalation of average levels of 
metals and the maximum PCB levels detected at the site was 0.0002 . The maximum PCB level was used because an average was not available. Exposure to the maximum soil levels for the entire duration of the removal action would result in a cumulative exposure of 0.014 . These estimates were additionally conservative because the PELs used were adjusted downward to account for potential exposure periods greater than 8 hours.

Of the contaminants of potential concern at the site, arsenic, beryllium, cadmium, lead, nickel, and PCBs are considered known or probable human carcinogens. Average soil metal levels and the maximum PCB level would result in an estimated inhalation carcinogenic risk of $9.1 \times 10^{-8}$ for removal action workers. (This risk does not include the risk from lead, for which carcinogenic toxicity values are not currently available.) The inhalation carcinogenic risk based on maximum soil concentrations was estimated as $9.4 \times 10^{-7}$. These values indicate that the inhalation carcinogenic risk to removal action workers would be less than the range of $10^{-4}$ to $10^{-6}$ considered acceptable for hazardous waste sites nationwide (U.S. EPA 1990).

The carcinogenic risk associated with dermal exposure to the maximum $P C B$ concentration in soils was estimated to be $8.1 \times 10^{-6}$, assuming that one-half of the surface area of the hands and arms is covered with dirt for some period of each work day. This carcinogenic risk from dermal exposure to PCBs falls within the acceptable risk range of $10^{-4}$ to $10^{-6}$. Workers would also wear protective clothing during the removal action to minimize exposure. The Health and Safety Plan for the site specifies that workers must wear Tyvek coveralls, rubber boots, and neoprene gloves (Bechtel National 1989b).

Under Alternative 3, some site areas in which elevated soil metal levels have been detected would not be excavated. To determine whether these areas could present health risks under future site uses, an ingestion hazard index (i.e., measure of noncarcinogenic toxicity) and carcinogenic risks for inhalation and ingestion for a hypothetical future resident at the site were calculated. (Currently available toxicity data are inadequate for the calculation of an inhalation hazard index.) Metals data for all boreholes were used, with the exception of the four boreholes with elevated lead levels which would be excavated under Alternative 3 . The resident scenario assumed an inhalation rate of $1.2 \mathrm{~m}^{3} / \mathrm{h}, 20 \mathrm{~h} /$ day on-site; an incidental soil-ingestion rate of $100 \mathrm{mg} /$ day, 40 times/year; an adult body weight of $70 \mathrm{~kg}$; and an exposure duration of 70 years. As recommended by EPA (1989a), the 95 th percentile upper confidence intervals on the mean soil metal levels were used as input values, and reference doses and slope factors from the EPA's Integrated Risk Information System were incorporated into risk calculations.

The ingestion hazard index calculated for the hypothetical future resident was 0.21 . (A hazard index of less than 1 indicates that toxicity is unlikely.) The carcinogenic risk due to inhalation was $1.7 \times 10^{-5}$, and the risk due to ingestion was $1.4 \times 10^{-5}$. These numbers indicate that the metals remaining in site soil after the proposed removal action at the Elza Gate Site would not present significant health risks under a conservative but reasonable future land-use scenario.

Transporting the materials to the ORR would require an estimated total of 1100 truck trips. The one-way trip haul distance is estimated to be $16 \mathrm{~km}$ (10 mi) and bypasses the city of Oak Ridge; roads that do not traverse residential areas would be used. The gamma exposure risks to the public during the transportation phase are assumed to be negligible since the truck is a shield, the distance from the wastes to a roadside person are relatively large, and the period of potential exposure is very short. Transportation accident risks were computed for the 
22,000 miles of truck travel (1100 round-trips of $20 \mathrm{mi}$ ) as $3.3 \times 10^{-2}$ (Cashwell et al. 1986). This was based on injuries and fatalities to the driver and to bystanders.

\subsubsection{Timeliness}

Removal action at the Elza Gate site in the near future is desirable, since the site is privately owned, is planned to undergo development as an industrial park, and involves an operating business where the business owner is supportive of the proposed removal action. Modification of the property is expected to continue as it is developed, leased, or sold. Thus, the removal of contamination in the 1991 construction season with off-site storage or disposal (Alternative 3) would provide for the timely remedial action and certification of the site without radiological restrictions that is required to reduce potential hazards to the general public, both on-site and off-site, without impairing site-related business activities.

\subsubsection{Technical Feasibility}

Technical feasibility does not apply to Alternative 1, the no-action alternative, since this maintains the status quo. Alternative 2 is not an adequate solution in terms of protection of public health and welfare and the environment. Alternative 3 has been implemented for similar conditions and involves commonly used techniques and equipment. It is technically feasible and readily implementable.

\subsubsection{Effectiveness}

The effectiveness of an alternative is defined by its effectiveness in ensuring protection of and minimizing impacts to human health and the environment. Neither Alternative 1 nor Alternative 2 can adequately provide this assurance. However, under Alternative 3, contaminants can be removed so that residual levels represent no significant acute or chronic risks to potential workers, residents or visitors on the Elza Gate site.

\subsubsection{Cost}

The estimated subcontract cost for implementing Alternative 2 (interim storage at the Elza Gate site) is $\$ 1.7$ million while that for Alternative 3 (storage or disposal on the ORR) is about $\$ 1.8$ million, the differential being about $\$ 145,000$ due to transportation costs. The cost savings represented by this estimate, because of less site preparation at the Elza Gate site, are slight, on the order of a few tenths of a percent of the total project cost. Costs entail excavation of contaminants, including excavation and commercial disposal of PCBs, construction of an interim storage cell (if necessary), site restoration, annual surveillance and maintenance at ORR, transportation under Alternative 3 (but not Alternative 2), subcontracts, engineering, environmental health and safety, support, procurement, office overhead, and contingencies. The cost benefit of Alternative 3 is associated with the removal of contaminated material from the Elza Gate site, which limits the potential costs related to (1) exposure of persons working on or visiting the site, (2) cleanup of areas that might become contaminated as a result of future migration of contamination, and (3) potential long-term monitoring of the site that may be required. 


\subsection{IDENTIFICATION OF PROPOSED ALTERNATIVE}

Alternative 3 has been identified as a timely, technically feasible, and cost-effective alternative that protects human health and welfare and the environment. The health and environmental advantages of removing the contaminated materials from the Elza Gate site are clearly beneficial. The potential for unnecessary exposure of persons working on and visiting the site and for uncontrolled releases is obvious under the no-action alternative. Alternative 2 attempts to control potential exposures and releases but at the cost of long-term surveillance of a site not designed for extended storage of hazardous materials. Moreover, long-term storage would create an impediment to commercial development of the industrial park. Under Alternative 3, material can be relocated to a more secure location and one already developed to handle hazardous materials. Whether disposal or storage occurs on the ORR, it is a much more desirable solution than no action or interim on-site storage at Elza Gate. All removal action objectives can be performed in a timely manner. Therefore, the recommended removal action for the Elza Gate site is Alternative 3 - removal (excavation, decontamination, demolition, and shipment) of contaminated materials to an off-site storage or disposal facility at the ORR. PCB wastes with concentrations in excess of $50 \mathrm{ppm}$ would be disposed of at a commercial TSCA facility. 


\section{PROPOSED REMOVAL ACTION}

\subsection{DESCRIPTION OF REMOVAL ACTION ACTIVITIES}

Under the proposed removal action, the contaminated materials at the Elza Gate site would be removed and transported to the ORR for storage or disposal. The contaminated materials would consist of radiologically contaminated soil and rubble, soils containing PCBs under the 50-ppm guideline (both alone and mixed with radioactively contaminated material), and soils containing greater than $1,000 \mathrm{ppm}$ lead. Soils containing PCBs in excess of $50 \mathrm{ppm}$ would be containerized and shipped to a licensed TSCA disposal facility. The removal action would consist of excavating contaminated soil, gravel, and asphalt. Also, several concrete slabs would be reduced in size for easier handling, and uncontaminated portions would be segregated for disposal at a sanitary landfill. A temporary facility was constructed to accommodate storage of the contaminated materials from the Pad 1 cleanup. This facility would also be utilized for the proposed removal action. The construction included establishing a temporary decontamination facility at the excavation site. A similar facility would be built at the ORR disposal or interim storage site. Construction may also include building any necessary haul roads and a dumping ramp. If a disposal site undergoing RCRA closure on the ORR is utilized, no special preparation will be necessary beyond that already planned for the closure operation. If a storage site is utilized, the area designated at the ORR for storage would be prepared by removing the vegetation, grading the ground surface to achieve the desired profile, compacting the surface, and constructing drainage swales and berms to control runon and runoff.

The boundaries of excavation at the Elza Gate site would be established on the basis of existing chemical and radiological data and field verification data. The property owner's consent to implement a removal action on the property would be secured through an access agreement defining DOE's responsibilities and liabilities with regard to cleanup. The contaminated areas would be excavated using conventional earth-moving equipment, and the contaminated materials would be placed in containers or dump trucks. The concrete slabs would be reduced in size with conventional equipment. The reduced pieces of concrete would be lifted on their sides and decontaminated, if possible, by removing loose contamination. During excavation, the soil would be kept moist to minimize the generation and release of dust. Runon and runoff controls (filter fabric, hay bales, etc.) would be implemented during excavation. Upon receipt of data confirming that all soil contaminated above guideline levels had been removed, the excavated area would be backfilled with clean fill, and the area would be restored to acceptable conditions by seeding grass, repairing asphalt, and replacing fences as applicable.

The exteriors of the loaded trucks would be radiologically surveyed prior to release from the Elza Gate site for the trip to the ORR. All trucks would be below radiological surface contamination limits and would be placarded with the appropriate labels. Transportation routes would be established, and an emergency response plan would be in place. During all truck travel on public roads (loaded or return trips), truck beds would be covered by tarpaulins to contain the contaminated materials and avoid dust generation and release. At the ORR the empty trucks would be driven to a portable decontamination pad where they would be surveyed and, if necessary, decontaminated before their return trip.

The contaminated materials would be unloaded from the trucks and would be placed in either a disposal site or in an interim storage area at the ORR (discussed below under Secs. 5.2.1 through 5.2.4). For the disposal sites, the contaminated material would be added as 
fill to the planned capping operation as specified in the closure plan. For interim storage, the area would be lined with a geomembrane and have geotextiles on both sides to protect against puncturing the liner. Contaminated material placed on the pile would be compacted using standard equipment. During placement of contaminated material, a temporary cover would be installed over the pile at the end of each day and anchored with concrete blocks. The cover would be routinely inspected and repaired, if necessary, during the filling of the storage site. After all material had been placed in storage, a geotextile and then a geomembrane cover would be placed on top of the pile. The perimeter of the pile would be trench-anchored, and concrete blocks and/or sandbags would be placed on top of the cover as additional anchorage. The geomembrane liner and cover would be a 30-mil, very low density polyethylene. This material was chosen for its low moisture transmission, high tensile strength, flexibility, ultraviolet light stability, and resistance to insects and rodents.

Polychlorinated biphenyl wastes would be excavated and containerized for shipment to an appropriate TSCA-regulated landfill. The radiological content of this material would be closely monitored to ensure that a mixed waste was not generated. The storage facilities will meet the standards set forth in 40 CFR 761.65 for PCB-contaminated material.

The environment at the Elza Gate site and the storage/disposal site at the ORR would be monitored during cleanup activities to ensure compliance with all requirements. Mitigative measures, such as dust control during excavation and grading and runoff controls to limit erosion and sediment transport, would be employed to reduce the risk of significant adverse environmental consequences. When the removal activities were completed, the affected area would be restored according to an agreement established with the property owner.

\subsection{OPTIONS AT THE OAK RIDGE RESERVATION UNDER THE PREFERRED ALTERNATIVE}

Under the preferred alternative (i.e., disposition at the ORR), there are four available options:

- Disposal at the ORNL Waste Area Grouping 6;

- Disposal on the United Nuclear Corporation Chestnut Ridge Disposal Site at the Oak Ridge Y-12 Plant;

- Interim storage on the East Central Chestnut Ridge site at the Oak Ridge Y-12 Plant; and

- Interim storage at the Solid Waste Storage Area (SWSA) 7X in the Melton Valley east of the ORNL main facilities.

Under the disposal options, the Elza Gate wastes would be utilized as fill for the closure process at the facility. Under the interim storage options, a new waste area would be developed on the site specifically for the Elza Gate wastes. 


\subsubsection{Waste Area Grouping 6}

During several decades of operations at the ORNL, various radioactive and hazardous chemicals have been handled and disposed of on the ORR. Moreover, the AEC designated ORNL as the Southern Regional Burial Ground so that additional materials were received from off-laboratory sites. Some of this waste went to Waste Area Grouping (WAG) 6. The wastes there cannot be fully characterized but are known to consist of at least fission products, transuranics, uranium isotopes, and radium in solid, liquid, and biological materials from low to high exposure levels. Undoubtedly, many chemical wastes went into WAG 6 also. It is believed the hazardous chemicals of principal interest there are lead, xylene, and toluene. A portion of WAG 6, known as the Solid Waste Storage Area (SWSA) 6, is now undergoing closure under the RCRA. One potential disposition of the Elza Gate wastes is to incorporate them with the fill necessary to construct the cap for closure. In comparison to the quantities of contaminants already there, the Elza Gate wastes would represent a small incremental addition.

\subsubsection{United Nuclear Corporation Chestnut Ridge Disposal Site}

The United Nuclear Corporation disposal site is located near the crest of Chestnut Ridge in the southern portion of the Y-12 Plant in Oak Ridge, Tennessee. For two years this site received waste from the decommissioning of a corporation uranium recovery facility. Waste materials consisted of drums of sludge fixed in cement, drums of contaminated soil, and wooden boxes of contaminated building and process demolition materials. The contaminants of concern in the source material are nitrates and strontium-90. This site is now subject to closure under RCRA and CERCLA. The preferred alternative is capping the waste materials with a modified RCRA cap for long-term minimization of infiltration. Elza Gate wastes could be incorporated beneath the cap as fill material.

\subsubsection{East Central Chestnut Ridge Disposal Site}

The East Central Chestnut Ridge disposal site consists of about 3 acres of undeveloped, wooded land west of the Y-12 Industrial Waste Landfill 4. Other waste disposal and storage facilities are also located in this area. The site is essentially flat, is removed from surface water bodies, contains thick soils, and has a deep water table. Access can be obtained near the landfill. Under this proposal, an interim storage site would be constructed and the Elza Gate wastes encapsulated in a sealed membrane.

\subsubsection{Solid Waste Storage Area (SWSA) $7 \mathrm{X}$}

The SWSA 7X site consists of more than 20 acres of relatively flat wooded land and is a southeast extension of SWSA 7 in Melton Valley east of the ORNL main facilities. The site is attractive largely because of land availability, ease of access, and minimal grading requirements. Potential deficiencies are the shallow depth to groundwater and thin soils. Because it was included in the environmental characterization of SWSA 7 for future waste disposal, a robust background environmental database is available. Under this proposal, an interim storage site would be constructed and the Elza Gate wastes encapsulated in a sealed membrane. 


\subsection{CONCLUSION}

The preferred alternative for the Elza Gate wastes is Alternative 3, that is, disposal or interim storage on the ORR. The exact disposition, whether disposal in one of two waste areas undergoing closure or interim storage in one of two presently utilized waste disposal areas, would be determined through negotiations proceeding concurrently with the comment period on this document. Alternative 3 presents the best solution because it removes hazardous materials from the public domain, forecloses any further dispersal of these materials from private property, and places the materials within the confines of a site already containing hazardous materials and within an enclosure specifically designed for hazardous materials containment. This alternative provides a feasible solution that would effectively resolve the contamination problem at the Elza Gate site in a timely manner and at a justifiable cost. 


\section{REFERENCES}

Argonne National Laboratory, 1989, Action Description Memorandum, Demonstration of the Effectiveness of Abrasive Blasting Techniques for Decontaminating Concrete Pads at the Elza Gate Site, Oak Ridge, Tennessee, prepared by Energy and Environmental Systems Division, Argonne, Ill., for U.S. Department of Energy, Oak Ridge Operations, Oak Ridge, Tenn. (May).

Bechtel National, Inc., 1989a, letter from S.D. Liedle to W.M. Seay (DOE-ORO), "Report on Preliminary Characterization Activities on the Elza Gate Site," BNI CCN 064103, Oak Ridge, Tenn.

Bechtel National, Inc, 1989b, Health and Safety Plan for the Elza Gate Site, prepared for U.S. Department of Energy, Oak Ridge Operations Office, Oak Ridge, Tenn. (Feb.).

Bechtel National, Inc., 1991, unpublished information, prepared for U.S. Department of Energy, Oak Ridge Operations Office, Oak Ridge, Tenn. (March).

Cashwell, J.W., et al., 1986, Transportation Impacts on the Commercial Radioactive Waste Management Program, Sandia National Laboratory, Albuquerque, N.M. (April).

Cheng, J.-J., et al., 1991, Derivation of Uranium Residual Radioactive Material Guidelines for the Elza Gate Site, Argonne National Laboratory Report (unnumbered), prepared for U.S. Department of Energy, Oak Ridge Operations (Feb.).

Cottrell, W.D., J.L. Quillen, and R.F. Carrier, 1989, Preliminary Site Survey Report for the Former Elza Gate Warehouse Area, Oak Ridge, Tennessee, Report ORNL/RASA-89/4, Oak Ridge National Laboratory, Oak Ridge, Tenn. (Sept.).

Devgun, J.S., R.R. Land, and R.W. Doane, 1990, Demonstration Experience with an Abrasive Blasting Technique for Decontaminating Concrete Pads, Vol. 2, Proc. Waste Management ' 90 Conference, Tucson, Ariz., Feb. 25-Mar. 1.

Egli, R.L., 1988, "Sampling Data for Land Parcel 228," letter from R.L. Egli (DOE-OR) to K. Cole (Oak Ridge, Tenn) (April 25). (Copy available from U.S. Department of Energy, Oak Ridge Operations, Former Sites Restoration Division, Oak Ridge, Tenn.)

Fiore, J.J., 1988, "Authorization for Remedial Action at the Melton Lake Industrial Park (Former Elza Gate Area Warehouses), Oak Ridge, Tennessee," memorandum from J.J. Fiore (Director, Division of Facility and Site Decommissioning Projects, Office of Nuclear Energy, U.S. Department of Energy, Washington, D.C.) to P. Gross (Oak Ridge Operations, Technical Services Division, U.S. Department of Energy, Oak Ridge, Tenn.) (Nov. 30).

Gilbert, T.L., et al., 1989, A Manual for Implementing Residual Radioactive Material Guidelines, ANL/ES-160; DOE/CH/8901, prepared by Argonne National Laboratory, Energy and Environmental Systems Division, Argonne, [ll., for U.S. Department of Energy, Assistant Secretary for Nuclear Energy (June).

Liedle, S.D., 1990a, letter from S.D. Liedle (Bechtel National, Inc, Oak Ridge, Tenn.) to J.S. Devgun (Argonne National Laboratory, Argonne, I11.) (Sept. 20). 
Liedle, S.D., 1990b, letter from S.D. Liedle (Bechtel National Inc, Oak Ridge, Tenn.) to D.G. Adler (U.S. DOE, Oak Ridge) (Dec. 10).

Liedle, S.D., 1991, letter from S.D. Liedle (Bechtel Nataional, Inc., Oak Ridge, Tenn.) to D.G. Adler (U.S. DOE, Oak Ridge), Subject: Toxicity Characteristic Metals Results for the Elza Gate Site (March 27).

Poligone M., 1990a, letter from M. Poligone (Bechtel National, Inc., Oak Ridge, Tenn.) to J. S. Devgun (Argonne National Laboratory, Argonne, 111.) (Oct. 9).

Poligone M., 1990b, letter from M. Poligone (Bechtel National, Inc., Oak Ridge, Tenn) to J. S. Devgun (Argonne National Laboratory, Argonne, I11.) (Nov. 26).

Sapirie, S.R., 1972, "Disposal of Excess Real Property - Parcel 228," letter from S.R. Sapirie to J.L. Smith (Attachment: Authorization for Remedial Action at the Melton Lake Industrial Park [former Elza Gate Area Warehouses]), Bechtel National, Inc., BNI CCN 057470, Oak Ridge, Tenn. (Feb. 3).

Seiler, H.G., and H. Sigel, eds., 1988, Handbook on Toxicity of Inorganic Compounds, Ch. 63, Marcel Dekker, Inc., New York City.

U.S. Department of Energy, 1988, Radiation Protection for Occupational Workers, DOE Order 5480.11, Washington, D.C. (Dec. 21).

U.S. Department of Energy 1990a, Engineering Evaluation/Cost Analysis for the Proposed Removal of Contaminated Materials from Pad 1 at the Elza Gate Site, Oak Ridge, Tennessee, DOE/OR/23701372, (Sept.).

U.S. Department of Energy, 1990b, Radiation Protection of the Public and the Environment, DOE Order 5400.5, Washington, D.C. (Feb. 8).

U.S. Department of Labor, Occupational Safety and Health Administration, 1989, Air Contaminants - Permissible Exposure Limits (29 CFR 1910.1000).

U.S. Environmental Protection Agency, 1987a, Radiation Protection Guidance to Federal Agencies for Occupational Exposure; Approval of Environmental Protection Agency Recommendations, Part II, Washington, D.C. (Jan. 27).

U.S. Environmental Protection Agency, 1987b, Superfund Program; Interim Guidance on Compliance with Other Applicable or Relevant and Appropriate Requirements, Federal Register, 52(166):3249632499 (Aug. 27).

U.S. Environmental Protection Agency, 1989a, Risk Assessment Guidance for Superfund, Human Health Evaluation Manual, Part A: Interim Final, EPA/540/1-89/002, Office of Emergency and Remedial Response, Washington, D.C.

U.S. Environmental Protection Agency, 1989b, Interim Guidance on Establishing Lead Cleanup Levels at Superfund Sites, OSWER 9355.4-02, Office of Solid Waste and Emergency Response, Washington, D.C. (Sept.). 
U.S. Environmental Protection Agency, 1989c, Exposure Factors Handbook, EPA/600/8-89/043, Office of Health and Environmental Assessment, Washington, D.C. (July).

U.S. Environmental Protection Agency, 1989d, Risk Methodology, Environmental Impact Statement for NESHAPS Radionuclides, Vol. I, Background Information Document, Washington, D.C. (Sept.).

U.S. Environmental Protection Agency, 1990, National Oil and Hazardous Substances Contingency Plan; Final Rule (40 CFR 300), Federal Register, 55(76):869 (March 8).

Wagoner, J.W., II, 1991, memorandum to Lester K. Price (Director, Former Sites Restoration Division, Oak Ridge Operations Office, U.S. Department of Energy, Germantown, Md.) (Feb. 6). 


\section{LIST OF CONTRIBUTORS}

This EE/CA has been prepared by the DOE with contractual assistance from Argonne

National Laboratory and Bechtel National, Inc. The following individuals contributed to the preparation of this report.

Name Education/Expertise Contribution

\section{Argonne}

Larry W. Jensen

Jas S. Devgun

Christopher P. Dunn

Rebecca A. Haffenden

Heidi M. Hartmann

Manjula R. Nimmagadda

John H. Cleland
M.S., radiation health certified health physicist

13 years experience in radioactive waste management and environmental assessment

Ph.D., physical chemistry/ photon physics; P.D.F., chemical engineering 13 years experience in radioactive waste management/nuclear engineering/ environmental assessment

Ph.D., plant ecology 6 years experience in environmental assessment and monitoring

J.D., Suffolk University Law School

11 years experience in energy and environmental law

M.S., environmental toxicology 3 years experience in environmental assessment

M.S., health physics 1 year experience in environmental assessment

B.A., journalism, M.A., English 15 years technical writing and editing experience
Project leader, response to comments, analysis of alternatives, technical review

Project leader, 1st draft; site setting and history, removal action technologies, removal action justification, analysis of alternatives, technical review

Evaluation of Wetland Issues

Applicable or relevant and appropriate requirements

Chemical assessment, pathway exposure assessment

Radiological assessment

Technical editing 


\begin{tabular}{|c|c|c|}
\hline Name & Education/Expertise & Contribution \\
\hline Patricia E. Hollopeter & $\begin{array}{l}\text { B.A., religion, A.M., philosophy } \\
9 \text { years editorial experience }\end{array}$ & $\begin{array}{l}\text { Overall editorial } \\
\text { responsibility }\end{array}$ \\
\hline \multicolumn{3}{|l|}{ Bechtel } \\
\hline Karen Noey & $\begin{array}{l}\text { B.S., animal science } \\
7 \text { years experience in radio- } \\
\text { logical site assessments }\end{array}$ & $\begin{array}{l}\text { Analytical data, removal action } \\
\text { justification }\end{array}$ \\
\hline Mike Poligone & $\begin{array}{l}\text { B.S., civil engineering } \\
1 \text { year experience in } \\
\text { environmental engineering }\end{array}$ & $\begin{array}{l}\text { Removal action objectives and } \\
\text { techniques, analysis of } \\
\text { altematives }\end{array}$ \\
\hline Joe Williams & $\begin{array}{l}\text { B.S., civil engineering } \\
8 \text { years experience in field } \\
\text { engineering/decontamination/ } \\
\text { radwaste/environmental } \\
\text { engineering }\end{array}$ & $\begin{array}{l}\text { Removal action objectives and } \\
\text { techniques, analysis of } \\
\text { alternatives }\end{array}$ \\
\hline
\end{tabular}


APPENDIX

DETERMINATION OF APPLICABILITY OF ARAR AND TBC REQUIREMENTS 
5

$$
\begin{gathered}
\text { DO NCT M } \\
\text { THS OAGE }
\end{gathered}
$$




\section{APPENDIX \\ DETERMINATION OF APPLICABILITY OF ARAR AND TBC REQUTREMENTS}

The preliminary location-specific, contaminant-specific, and action-specific ARAR and TBC determinations for the proposed removal action at the Elza Gate site are indicated in Tables A.1, A.2, and A.3, respectively. Because this appendix presents a comprehensive list of requirements with considerable overlap of regulated conditions, all determinations have been identified as "potentially" applicable, relevant and appropriate, or to be considered. Prior to implementing the proposed action, the determination of ARARs and TBCs will be finalized. During finalization, the requirements identified as potentially applicable will be reviewed to confirm direct applicability; only one requirement will be finalized from among those that regulate the same conditions. For those identified as potentially relevant and appropriate and as TBC requirements, both the specific portion(s) of the requirements that have bearing on the proposed action and the manner in which compliance would be achieved will be finalized. After the finalization process, certain of the requirements will remain potentially an ARAR or a TBC requirement as the action proceeds, pending identification of the existence of their prerequisites or regulated conditions (e.g., the presence of cultural resources or threatened or endangered species in the affected area). 


\section{TABLE A.1 Potential Location-Specific Requirements}

\begin{tabular}{|c|c|c|c|c|c|}
\hline Potential ARAR & Location & Requirement & $\begin{array}{l}\text { Preliminary } \\
\text { Determination }\end{array}$ & Remarks & \\
\hline $\begin{array}{l}\text { Antiquity Act/Historic Sites Act } \\
\text { (16 USC 431-433; } 16 \text { USC 461-467; } \\
40 \text { CFR 6.301(a)) }\end{array}$ & Land & $\begin{array}{l}\text { Cultural resources, such as historic buildings and } \\
\text { sites and natural landmarks, must be preserved on } \\
\text { federal land to avoid adverse impacts. }\end{array}$ & $\begin{array}{l}\text { Potentially } \\
\text { applicable }\end{array}$ & $\begin{array}{l}\text { No adverse impacts to such resources are } \\
\text { expected to result from the proposed action; } \\
\text { however, if these resources were affected, the } \\
\text { requirement would be applicable. }\end{array}$ & \\
\hline $\begin{array}{l}\text { National Fistoric Preservation Act, } \\
\text { as amended (16 USC } 470 \text { et seq.; } \\
40 \text { CFR } 6.301(b) ; 36 \text { CFR } 800 \text { ) }\end{array}$ & Land & $\begin{array}{l}\text { The effect of any federally assisted undertaking must } \\
\text { be taken into account for any district, site, building, } \\
\text { structure, or object included in or eligible for the } \\
\text { National Register of Historic Places. }\end{array}$ & $\begin{array}{l}\text { Potentially } \\
\text { applicable }\end{array}$ & $\begin{array}{l}\text { No adverse impacts to such properties are } \\
\text { expected to result from the proposed action; } \\
\text { however, if these resources were affected, the } \\
\text { requirement would be applicable. }\end{array}$ & \\
\hline $\begin{array}{l}\text { Archeological and Historic Preservation Act } \\
\text { (16 USC 469; } 40 \text { CFR 6.301(c); PL 93-291; } 88 \\
\text { Stat. 174) }\end{array}$ & Land & $\begin{array}{l}\text { Prehistorical, historical, and archeological data that } \\
\text { might be destroyed as a result of a federal, federally } \\
\text { assisted, or federally licensed activity or program } \\
\text { must be preserved. }\end{array}$ & $\begin{array}{l}\text { Potentially } \\
\text { applicable }\end{array}$ & $\begin{array}{l}\text { No destruction of such data is expected to result } \\
\text { from the proposed action. The site has been } \\
\text { considerably disturbed by past human activities } \\
\text { and is therefore not expected to contain any } \\
\text { such data. However, if these data were affected, } \\
\text { the requirement would be applicable. }\end{array}$ & \\
\hline $\begin{array}{l}\text { Archeological Resources Protection Act (16 } \\
\text { USC } 470(\text { a)) }\end{array}$ & Iand & $\begin{array}{l}\text { A permit must be obtained if an action on public or } \\
\text { Indian lands could impact archeological resources. }\end{array}$ & $\begin{array}{l}\text { Potentially } \\
\text { applicable }\end{array}$ & $\begin{array}{l}\text { No impacts to archeological resources are } \\
\text { expected to result from the proposed action. } \\
\text { The site has been considerably disturbed by past } \\
\text { human activities and is therefore not expected to } \\
\text { contain any such resources. However, if these } \\
\text { resources were affected, the requirement would } \\
\text { be applicable. }\end{array}$ & $\mathbb{L}^{8}$ \\
\hline $\begin{array}{l}\text { Protection and Enhancement of the } \\
\text { Cultural Environment (Executive Order } \\
11593 ; 40 \text { CFR } 6.301 \text { ) }\end{array}$ & Land & $\begin{array}{l}\text { Historic, architectural, archeological, and cultural } \\
\text { resources must be preserved, restored, and } \\
\text { maintained, and must be evaluated for inclusion in } \\
\text { the National Register. }\end{array}$ & $\begin{array}{l}\text { Potentially } \\
\text { applicable }\end{array}$ & $\begin{array}{l}\text { No impacts to such resources are expected to } \\
\text { result from the proposed action. The site has } \\
\text { been considerably disturbed by past human } \\
\text { activities and is therefore not expected to contain } \\
\text { any such resources. However, if these resources } \\
\text { were affected, the requirement would be } \\
\text { applicable. }\end{array}$ & \\
\hline $\begin{array}{l}\text { Endangered Species Act, as amended ( } 16 \\
\text { USC 1531-1543; } \\
50 \text { CFR 17.402; } 40 \text { CFR 6.302(h)) }\end{array}$ & Any & $\begin{array}{l}\text { Federal agencies must ensure that any action } \\
\text { authorized, funded, or carried out by the agency is } \\
\text { not likely to jeopardize the continued existence of } \\
\text { any threatened or endangered species or destroy or } \\
\text { adversely modify any critical habitat. }\end{array}$ & $\begin{array}{l}\text { Potentially } \\
\text { applicable }\end{array}$ & $\begin{array}{l}\text { No critical habitat exists in the affected area, and } \\
\text { no adverse impacts to threatened or endangered } \\
\text { species are expected to result from the proposed } \\
\text { action; however, if such species were affected, } \\
\text { the requirement would be applicable. }\end{array}$ & \\
\hline $\begin{array}{l}\text { Fish and Wildlife Coordination Act } \\
\text { (14 USC } 441-444 ; 40 \text { CFR } 4.302(a) \text { ) }\end{array}$ & Any & $\begin{array}{l}\text { Adequate protection of fish and wildlife resources is } \\
\text { required when any federal department or agency } \\
\text { proposes or authorizes any modification (e.g., } \\
\text { diversion or channeling) of any stream or other water } \\
\text { body or any modification of areas affecting any } \\
\text { stream or other water body. }\end{array}$ & Not an ARAR & $\begin{array}{l}\text { No modification of streams or stream areas is } \\
\text { planned as part of the proposed action. }\end{array}$ & \\
\hline
\end{tabular}


TABLE A.1 (Cont'd)

\begin{tabular}{|c|c|c|c|c|}
\hline Potential ARAR & Location & Requirement & $\begin{array}{l}\text { Preliminary } \\
\text { Determination }\end{array}$ & Remarks \\
\hline $\begin{array}{l}\text { Tennessee Non-Game and Endangered or } \\
\text { Threatened Wildlife Species Act of } 1974 \\
\text { (TCA \& 70-8-101 et seq.) and Tennessee } \\
\text { Rare Plant Protection and Conservation Act } \\
\text { of } 1985 \text { (TCA } \$ 11-26-201 \text { et seq.) }\end{array}$ & Any & $\begin{array}{l}\text { Species "in need of management", as designated by } \\
\text { the Tennessee conservation agency, must not be } \\
\text { destroyed or adversely affected. }\end{array}$ & $\begin{array}{l}\text { Potentially } \\
\text { applicable }\end{array}$ & $\begin{array}{l}\text { If any such species or critical habitat were } \\
\text { identified at the site and would be affected by } \\
\text { the proposed removal action, these requirements } \\
\text { would be applicable. }\end{array}$ \\
\hline $\begin{array}{l}\text { Floodplain Management (Executive Order } \\
\text { 11988; 10 CFR 1022) }\end{array}$ & Floodplain & $\begin{array}{l}\text { Federal agencies must avoid, to the maximum extent } \\
\text { possible, any adverse impacts associated with direct } \\
\text { and indirect development of a floodplain. }\end{array}$ & Not an ARAR & The site is not within the 100-year floodplain. \\
\hline $\begin{array}{l}\text { Protection of Wetlands (Executive } \\
\text { Order 11990; } 10 \text { CFR 1022) }\end{array}$ & Wetland & $\begin{array}{l}\text { Federal agencies must avoid, to the extent possible, } \\
\text { any adverse impacts associated with the destruction } \\
\text { or loss of wetlands and the support of new } \\
\text { construction in wellands if a practicable altemative } \\
\text { exists. }\end{array}$ & Not an ARAR & No wetlands exist in the affected area. \\
\hline
\end{tabular}




\section{TABLE A.2 Potential Contaminant-Specific Requirements}

\begin{tabular}{|c|c|c|c|c|c|c|}
\hline Potential ARAR & Contaminant & Medium & Requirement & & $\begin{array}{c}\text { Preliminary } \\
\text { Determination }\end{array}$ & Remarks \\
\hline \multirow{5}{*}{$\begin{array}{l}\text { Occupational Safety and } \\
\text { Health Administration } \\
\text { Standards; Occupational } \\
\text { Health and Environmental } \\
\text { Control (29'CFR 1910; } \\
\text { 1910.96), Subpart G, } \\
\text { Ionizing Radiation }\end{array}$} & \multirow[t]{5}{*}{ Radiation } & \multirow[t]{5}{*}{ Any } & \multicolumn{2}{|c|}{$\begin{array}{l}\text { The dose per calendar quarter resulting from exposure to } \\
\text { radiation in a restricted area from sources in that area is } \\
\text { limited to the following. }\end{array}$} & \multirow[t]{5}{*}{$\begin{array}{l}\text { Potentially } \\
\text { applicable }\end{array}$} & \multirow{5}{*}{$\begin{array}{l}\text { These requirements are part of an employee } \\
\text { protection law (rather than an } \\
\text { environmental law) with which all } \\
\text { CERCLA response actions should comply. } \\
\text { Because this compliance is directly } \\
\text { required, as promulgated in the NCP, these } \\
\text { requirements are not subject to evaluation } \\
\text { for attainment or waiver as part of the } \\
\text { ARAR process. However, they constitute } \\
\text { requirements for worker protection with } \\
\text { which the proposed action will comply. }\end{array}$} \\
\hline & & & Part of Body & $\begin{array}{l}\text { Dose } \\
\text { (rem) }\end{array}$ & & \\
\hline & & & $\begin{array}{l}\text { Whole body: head and trunk, } \\
\text { active blood-forming organs, } \\
\text { lens of eye, or gonads }\end{array}$ & $11 / 4$ & & \\
\hline & & & $\begin{array}{l}\text { Hands and forearms, feet } \\
\text { and ankles }\end{array}$ & $183 / 4$ & & \\
\hline & & & Skin of whole body & $71 / 2$ & & \\
\hline
\end{tabular}

The occupational exposure of an individual younger than 18 is restricted to $10 \%$ of these limits; the whole-body dose to a worker may not exceed $3 \mathrm{rem}$ in a calendar quarter, and when added to the cumulative occupational dose may not when added to the cumulative occupational dose may not
exceed $5(N-18)$ rem, where $N$ is the age of the exposed individual. 
TABLE A.2 (Cont'd)

\begin{tabular}{|c|c|c|c|c|c|c|}
\hline Potential ARAR & Contaminant & Medium & Requir & & $\begin{array}{c}\text { Preliminary } \\
\text { Determination }\end{array}$ & Remarks \\
\hline \multirow[t]{7}{*}{$\begin{array}{l}\text { Radiation Protection for } \\
\text { Occupational Workers } \\
\text { (DOE Order 5480.11) }\end{array}$} & \multirow[t]{7}{*}{ Radiation } & \multirow[t]{7}{*}{ Any } & \multicolumn{2}{|c|}{$\begin{array}{l}\text { The effective dose equivalent received by any member of the } \\
\text { public entering a controlled area is limited to } 100 \mathrm{mrem} / \mathrm{yr} \text {. } \\
\text { Limiting values for the assessed dose from exposure of } \\
\text { workers to radiation are as follows. (These values represent } \\
\text { maximum limits; it is DOE policy to maintain radiation } \\
\text { exposures as far below these limits as is reasonably } \\
\text { achievable.) }\end{array}$} & \multirow[t]{7}{*}{ To be considered } & \multirow[t]{2}{*}{$\begin{array}{l}\text { Although not promulgated standards, these } \\
\text { constitute requirements for protection from } \\
\text { radionuclide emissions in a controlled area } \\
\text { with which the proposed action will } \\
\text { comply. }\end{array}$} \\
\hline & & & Radiation Effect & $\begin{array}{c}\text { Annual } \\
\text { Dose Equivalent } \\
\text { (rem) }\end{array}$ & & \\
\hline & & & Stochastic effects & $5^{a}$ & & \\
\hline & & & \multicolumn{2}{|l|}{ Nonstochastic effects } & & \\
\hline & & & Lens of eye & 15 & & \\
\hline & & & $\begin{array}{l}\text { Organ, extremity, } \\
\text { or tissue including } \\
\text { skin of whole body }\end{array}$ & 50 & & \\
\hline & & & $\begin{array}{l}\text { Unborn child, entire } \\
\text { gestation period }\end{array}$ & 0.5 & & \\
\hline
\end{tabular}


TABLE A.2 (Cont'd)

\begin{tabular}{|c|c|c|c|c|c|}
\hline Potential ARAR & Contaminant & Medium & Requirement & $\begin{array}{c}\text { Preliminary } \\
\text { Determination }\end{array}$ & Remarks \\
\hline $\begin{array}{l}\text { Standards for Protection } \\
\text { against Radiation (Rules of } \\
\text { Tennessee Department of } \\
\text { Health and Environment, } \\
\text { Bureau of Environment, } \\
\text { Division of Radiological } \\
\text { Health, Chapter } 1200-2-5, \\
\text { Section .04, Exposure of } \\
\text { Individuals in Restricted } \\
\text { Areas }\end{array}$ & Radiation & Any & $\begin{array}{l}\text { No individual in a restricted area shall receive in any one } \\
\text { calendar quarter a total occupational dose in excess of: } \\
\text { Whole body; hand and trunk, } \\
\text { active blood-forming organs, } \\
\text { lens of eyes or gonads } \\
\text { Hand and forearms, feet and } \\
\text { ankles } \\
\text { Skin of whole body } \\
\text { Except, exposure to the whole body may exceed the above } \\
\text { values provided exposure does not exceed } 3 \text { rem /quarter and } \\
\text { the dose to the whole body when added to the accumlated } \\
\text { dose to the whole body shall not exceed } 5(\mathrm{~N}-18) \text { rems where } \\
\mathrm{N}=\text { individual's age in years at his last birthday. No person } \\
\text { may cause any individual under } 18 \text { years of age within a } \\
\text { restricted area to receive in any period of one calendar } \\
\text { quarter, from all sources of radiation, a dose in excess of } 10 \% \\
\text { of the limits specified above (1200-2-5-.06). }\end{array}$ & $\begin{array}{l}\text { Potentially } \\
\text { applicable }\end{array}$ & $\begin{array}{l}\text { These requirements may be applicable to } \\
\text { the protection of workers at the site duxing } \\
\text { implementation of the removal action. }\end{array}$ \\
\hline $\begin{array}{l}\text { Standards for Protection } \\
\text { against Radiation (Rules of } \\
\text { Tennessee Department of } \\
\text { Health and Environment, } \\
\text { Bureau of Environment, } \\
\text { Division of Radiological } \\
\text { Health, Chapter } 1200-2-5 \text {, } \\
\text { Section .07, Permissible Levels } \\
\text { of Radiation from External }\end{array}$ & Radiation & Any & $\begin{array}{l}\text { The exposure limit for any member of the public in an } \\
\text { unrestricted area is limited to radiation levels which, if an } \\
\text { individual were continuously present in the area, could result } \\
\text { in his receiving a dose in excess of } 2 \text { mrem in any one hour, } \\
\text { or in excess of } 100 \text { mrem in any } 7 \text { consecutive days. Limits } \\
\text { in excess of those specified may be approved by the } \\
\text { Department of Health and Environment if the limits are not } \\
\text { likely to cause any individual to receive a dose to the whole } \\
\text { body in any period of one calendar year in excess of } 0.5 \text { rem. }\end{array}$ & $\begin{array}{l}\text { Potentially } \\
\text { applicable }\end{array}$ & $\begin{array}{l}\text { These requirements would be appliable for } \\
\text { the protection of the general public from } \\
\text { radionuclide emissions to uncontrolled } \\
\text { areas. }\end{array}$ \\
\hline
\end{tabular}


TABLE A.2 (Cont'd)

\begin{tabular}{|c|c|c|c|c|c|}
\hline Potential ARAR & Contaminant & Medium & Requirement & $\begin{array}{c}\text { Preliminary } \\
\text { Determination }\end{array}$ & Remarks \\
\hline $\begin{array}{l}\text { Radiation Protection of the } \\
\text { Public and the Environment } \\
\text { (DOE Order } 5400.5 \text { ) }\end{array}$ & Radiation & Air & $\begin{array}{l}\text { The basic dose limit for nonoccupationally exposed } \\
\text { individuals is } 100 \mathrm{mrem} / \mathrm{yr} \text { above background, committed } \\
\text { effective dose equivalent. Further, all radiation exposures } \\
\text { must be reduced to levels as low as reasonably achievable. }\end{array}$ & To be considered & $\begin{array}{l}\text { Although not promulgated standards, these } \\
\text { requirements are derived from such } \\
\text { standards and they consistute require-ments } \\
\text { for protection of the public with which the } \\
\text { proposed action will comply. }\end{array}$ \\
\hline $\begin{array}{l}\text { National Emission Standards } \\
\text { for Hazardous Air Pollutants } \\
\text { (40 CFR 61), Subpart H, } \\
\text { National Fmission Standards } \\
\text { for Emissions of Radio- } \\
\text { nuclides Other Than Radon } \\
\text { from Department of Energy } \\
\text { Facilities }\end{array}$ & $\begin{array}{l}\text { Radionuclides } \\
\text { other than } \\
\text { radon-220 and } \\
\text { radon-222 }\end{array}$ & Air & $\begin{array}{l}\text { Emissions of such radionuclides to the ambient air from DOE } \\
\text { facilities shall not exceed those amounts that would cause } \\
\text { any member of the public in any year an effective dose } \\
\text { equivalent of } 10 \mathrm{mrem} / \mathrm{yr} \text {. }\end{array}$ & $\begin{array}{l}\text { Potentially } \\
\text { relevant and } \\
\text { appropriate }\end{array}$ & $\begin{array}{l}\text { These requirements may be relevant and } \\
\text { appropriate to protection of the public } \\
\text { during implementation of the proposed } \\
\text { action, but are not applicable because the } \\
\text { Elza Gate site is not a DOE facility. }\end{array}$ \\
\hline $\begin{array}{l}\text { National Emission Standards } \\
\text { for Hazardous Air Pollutants } \\
\text { (40 CFR 61), Subpart } \Upsilon \\
\text { National Emission Standards } \\
\text { for Radon Emissions from the } \\
\text { Disposal of Uranium Mill } \\
\text { Tailings }\end{array}$ & Radon & Air & $\begin{array}{l}\text { Radon-222 emissions to ambient air from uranium mill } \\
\text { tailings piles that are no longer operational shall not exceed } \\
20 \mathrm{pCi} / \mathrm{m}^{2}-\mathrm{s} \text {. }\end{array}$ & . & $\begin{array}{l}\text { The Elza Gate site is not a mill tailings site, } \\
\text { so this requirement is not applicable; } \\
\text { however, it may be considered relevant and } \\
\text { appropriate. }\end{array}$ \\
\hline \multirow[t]{3}{*}{$\begin{array}{l}\text { Health and Environmental } \\
\text { Protection Standards for } \\
\text { Uranium and Thorium Mill } \\
\text { Tailings (40 CFR 192) }\end{array}$} & $\begin{array}{l}\text { External gamma } \\
\text { radiation }\end{array}$ & Air & $\begin{array}{l}\text { The level of external gamma radiation in any occupied or } \\
\text { habitable building must not exceed the background level by } \\
\text { more than } 20 \mu \mathrm{R} / \mathrm{h} \text {. }\end{array}$ & Not an ARAR & $\begin{array}{l}\text { The Elza Gate site is not a mill tailings site, } \\
\text { so these requirements are not applicable; } \\
\text { neither are they relevant and appropriate } \\
\text { because no habitable buildings would be } \\
\text { involved in the proposed action. }\end{array}$ \\
\hline & Radon & Air & $\begin{array}{l}\text { Releases of radon from tailings disposal piles must not } \\
\text { exceed an average rate of } 20 \mathrm{pCi} / \mathrm{m}^{2} \text {-s or increase the annual } \\
\text { average concentration in air outside the disposal site by more } \\
\text { than } 0.5 \mathrm{pCi} / \mathrm{L} \text {. }\end{array}$ & $\begin{array}{l}\text { Potentially } \\
\text { relevant and } \\
\text { appropriate }\end{array}$ & $\begin{array}{l}\text { The Elza Gate site is not a mill tailings site, } \\
\text { so these requirements are not applicable; } \\
\text { however, they may be considered relevant } \\
\text { and appropriate. }\end{array}$ \\
\hline & $\begin{array}{l}\text { Radon decay } \\
\text { products }\end{array}$ & Air & $\begin{array}{l}\text { The annual average (or equivalent) radon decay product } \\
\text { concentration, including background, in any habitable } \\
\text { building must not exceed } 0.02 \text { working level (WL) or a } \\
\text { maximum of } 0.03 \text { WL -- where a WL, is any combination of } \\
\text { short-lived radon decay products in } 1 \text { liter of air, without } \\
\text { regard to the degree of equilibrium, that will result in the }\end{array}$ & Not an ARAR & $\begin{array}{l}\text { The Elza Gate site is not a mill tailings site, } \\
\text { so these requirements are not applicable; } \\
\text { neither are they relevant and appropriate } \\
\text { because no habitable buildings are involved } \\
\text { in the proposed action. }\end{array}$ \\
\hline
\end{tabular}
in equilibrium with its of alpha energy. (For radon-222 
TABLE A.2 (Cont ${ }^{\prime} \mathrm{d}$ )

\begin{tabular}{|c|c|c|c|c|c|c|c|c|}
\hline Potential ARAR & Contaminant & Medium & \multicolumn{4}{|c|}{ Requirement } & $\begin{array}{l}\text { Preliminary } \\
\text { Determination }\end{array}$ & Remarks \\
\hline \multirow[t]{7}{*}{$\begin{array}{l}\text { Radiation Protection of the } \\
\text { Public and the Environment } \\
\text { (DOE Order 5400.5) }\end{array}$} & \multirow[t]{5}{*}{$\begin{array}{l}\text { Uranium, } \\
\text { thorium, and } \\
\text { radium }\end{array}$} & \multirow[t]{5}{*}{ Air } & \multicolumn{4}{|c|}{$\begin{array}{l}\text { Residual concentrations of radionuclides in air in } \\
\text { uncontrolled areas are limited to the following. (For known } \\
\text { mixtures of radionuclides, the sum of the ratios of the } \\
\text { observed concentration of each radionuclide to its } \\
\text { corresponding limit must not exceed 1.0.) }\end{array}$} & To be considered & $\begin{array}{l}\text { Although not promulgated standards, these } \\
\text { constitute requirements for protection of } \\
\text { the public with which the proposed action } \\
\text { will comply. }\end{array}$ \\
\hline & & & \multicolumn{4}{|c|}{$\begin{array}{l}\text { Derived Concentration Guide } \mathrm{e}^{\mathrm{a}} \\
(\mathrm{\mu Cl} / \mathrm{mL})\end{array}$} & & \\
\hline & & & Isotope & $\mathrm{D}$ & $w$ & $Y$ & & \\
\hline & & & $\begin{array}{l}\text { Uranium-238 } \\
\text { Thorium-232 } \\
\text { Thorium-230 } \\
\text { Radium-226 }\end{array}$ & $\begin{array}{l}5 \times 10^{-12} \\
-b \\
- \\
-\end{array}$ & $\begin{array}{l}2 \times 10^{-12} \\
7 \times 10^{-15} \\
4 \times 10^{-14} \\
1 \times 10^{-12}\end{array}$ & $\begin{array}{l}1 \times 10^{-13} \\
1 \times 10^{-14} \\
5 \times 10^{-14} \\
\end{array}$ & . & \\
\hline & & & \multicolumn{4}{|c|}{$\begin{array}{l}\text { a } \mathrm{D}, \mathrm{W} \text {, and } Y \text { represent lung retention classes; } \\
\text { removal half-times assigned to the compounds with } \\
\text { classes } \mathrm{D}, \mathrm{W} \text {, and } Y \text { are } 0.5,50 \text {, and } 500 \text { days, } \\
\text { respectively. Exposure conditions assume an } \\
\text { inhalation rate of } 8,400 \mathrm{~m}^{3} \text { of air per year } \\
\text { (based on an exposure over } 24 \text { hours per day, } \\
365 \text { days per year). } \\
{ }^{b} \text { A hyphen means no limit has been established. }\end{array}$} & . & \\
\hline & Radon-222 & Air & \multicolumn{4}{|c|}{$\begin{array}{l}\text { The above-background concentration of radon-222 in air } \\
\text { above an interim storage facility must not exceed } 100 \mathrm{pCi} / \mathrm{L} \\
\text { at any point, an annual average of } 30 \mathrm{pCi} / \mathrm{L} \text { over the facility, } \\
\text { or an annual average of } 3 \mathrm{pCi} / \mathrm{L} \text { at or above any location } \\
\text { outside the site. (See also the discussion for DOE Order } \\
5820.2 \mathrm{~A} \text { in Table G.3.) }\end{array}$} & To be considered & $\begin{array}{l}\text { Although not promulgated standards, these } \\
\text { constitute requirements for protection of } \\
\text { the public with which the proposed action } \\
\text { will comply. }\end{array}$ \\
\hline & $\begin{array}{l}\text { Radon-220 and } \\
\text { radon-222 }\end{array}$ & Aìr & \multicolumn{4}{|c|}{$\begin{array}{l}\text { The immersion derived concentration guide for both } \\
\text { radon- } 220 \text { and radon- } 222 \text { in air in an uncontrolled area is } \\
3 \mathrm{pCi} / \mathrm{L}\end{array}$} & To be considered & $\begin{array}{l}\text { Although not promulgated standards, these } \\
\text { constitute requirements for protection of } \\
\text { the public with which the proposed action } \\
\text { will comply. }\end{array}$ \\
\hline
\end{tabular}




\section{TABLE A.2 (Cont'd)}

\begin{tabular}{llll}
\hline \multicolumn{1}{c}{ Potential ARAR } & Contaminant & Medium & Requirement
\end{tabular}


TABLE A.2 (Cont'd)

\begin{tabular}{|c|c|c|c|c|c|c|c|}
\hline Potential ARAR & Contaminant & Medium & & Requiremen & & $\begin{array}{c}\text { Preliminary } \\
\text { Determination }\end{array}$ & Remarks \\
\hline \multirow{9}{*}{$\begin{array}{l}\text { Occupational Safety and } \\
\text { Health Administration } \\
\text { Standards; Occupational } \\
\text { Health and Environmental } \\
\text { Control (29 CFR 1910; } \\
\text { 1910.96), Subpart G, Ionizing } \\
\text { Radiation }\end{array}$} & \multirow[t]{9}{*}{$\begin{array}{l}\text { Uranium, } \\
\text { thorium, radium, } \\
\text { and radon }\end{array}$} & \multirow[t]{9}{*}{ Air } & \multicolumn{3}{|c|}{$\begin{array}{l}\text { Within a restricted area, airborne radioactive material } \\
\text { (averaged over a } 40 \text {-hour work week of seven consecutive } \\
\text { days) should not exceed the following limits. (For hours of } \\
\text { exposure less than or greater than } 40 \text {, the limits are } \\
\text { proportionately increased or decreased, respectively.) }\end{array}$} & \multirow[t]{9}{*}{$\begin{array}{l}\text { Potentially } \\
\text { applicable }\end{array}$} & \multirow{9}{*}{$\begin{array}{l}\text { These requirements are part of an employee } \\
\text { protection law (rather than an } \\
\text { environmental law) with which all } \\
\text { CERCLA response actions should comply. } \\
\text { Because this compliance is directly } \\
\text { required, as promulgated in the NCP, these } \\
\text { requirements are not subject to evaluation } \\
\text { for attainment or waiver as part of the } \\
\text { ARAR process. However, they constitute } \\
\text { requirements for worker protection with } \\
\text { which the proposed action will comply. }\end{array}$} \\
\hline & & & Isotope & $\begin{array}{c}\text { Solubility } \\
\text { Class }\end{array}$ & $\begin{array}{c}\text { Concentration } \\
(\mu \mathrm{Ci} / \mathrm{mL})\end{array}$ & & \\
\hline & & & Uranium-238 & $\begin{array}{l}\text { Soluble } \\
\text { Insoluble }\end{array}$ & $\begin{array}{l}3 \times 10^{-12} \\
5 \times 10^{-12}\end{array}$ & & \\
\hline & & & Thorium-232 & Soluble & $\begin{array}{l}1 \times 10^{-12} \\
1 \times 10^{-12}\end{array}$ & & \\
\hline & & & Thorium-230 & $\begin{array}{l}\text { Insoluble } \\
\text { Soluble } \\
\text { Insoluble }\end{array}$ & $\begin{array}{l}1 \times 10^{-12} \\
8 \times 10^{-14} \\
3 \times 10^{-13}\end{array}$ & & \\
\hline & & & Radium-226 & $\begin{array}{l}\text { Soluble } \\
\text { Insoluble }\end{array}$ & $\begin{array}{l}3 \times 10^{-12} \\
2 \times 10^{-12}\end{array}$ & & \\
\hline & & & $\begin{array}{l}\text { Radon-222 } \\
\text { Radon-220 }\end{array}$ & & $\begin{array}{l}3 \times 10^{-9} \\
1 \times 10^{-8}\end{array}$ & & \\
\hline & & & \multicolumn{3}{|c|}{$\begin{array}{l}\text { Limit is appropriate for radon- } 222 \text { combined } \\
\text { with its short-lived decay products and may } \\
\text { be replaced by } 1 / 30 \text { WL; the limit in } \\
\text { restricted areas may be based on an annual } \\
\text { average. }\end{array}$} & & \\
\hline & & & \multicolumn{3}{|c|}{$\begin{array}{l}\text { For mixtures of radionuclides, the sum of the ratios of the } \\
\text { quantity present to the specific limit must not exceed } 1 \text {. For } \\
\text { uranium, chemical toxicity may be the limiting factor for } \\
\text { soluble mixtures of uranium-238, uranium-235, and } \\
\text { uranium- }-234 \text { in air; if the percent by weight of uranium-235 } \\
\text { is less than } 5 \text {, the concentration limit for uranium is } \\
0.007 \mathrm{mg} / \mathrm{m}^{3} \text { inhaled air. }\end{array}$} & & \\
\hline
\end{tabular}


TABLE A.2 (Cont $\left.t^{\prime} d\right)$

\begin{tabular}{|c|c|c|c|c|c|c|c|c|}
\hline Potential ARAR & Contaminant & Medium & \multicolumn{4}{|c|}{ Requirement } & $\begin{array}{l}\text { Preliminary } \\
\text { Determination }\end{array}$ & Remarks \\
\hline \multirow[t]{5}{*}{$\begin{array}{l}\text { Radiation Protection for } \\
\text { Occupational Workers (DOE } \\
\text { Order 5480.11) }\end{array}$} & \multirow[t]{5}{*}{$\begin{array}{l}\text { Uranium, } \\
\text { thorium, radium, } \\
\text { and radon }\end{array}$} & \multirow[t]{5}{*}{ Air } & \multicolumn{4}{|c|}{$\begin{array}{l}\text { Occupational exposure limits for specific radionuclides in air } \\
\text { are as follows. (Values for radon isotopes assume } 100 \% \\
\text { equilibrium with the short-lived decay products; these values } \\
\text { may be replaced by } 1 \mathrm{WL} \text { for radon-220 and } 1 / 3 \mathrm{WL} \text { for } \\
\text { radon-222.) }\end{array}$} & To be considered & $\begin{array}{l}\text { Although not promulgated standards, these } \\
\text { constitute requirements for worker } \\
\text { protection with which the proposed action } \\
\text { will comply. }\end{array}$ \\
\hline & & & & \multicolumn{3}{|c|}{$\begin{array}{l}\text { Derived Concentration Guide }{ }^{\mathrm{a}} \\
\qquad(\mu \mathrm{Ci} / \mathrm{mL})\end{array}$} & & \\
\hline & & & lsotope & $\mathrm{D}$ & $w$ & $Y$ & & \\
\hline & & & $\begin{array}{l}\text { Uranium-238 } \\
\text { Thoriumi-232 } \\
\text { Thorium-230 } \\
\text { Radium-226 } \\
\text { Radon-222 } \\
\text { Radon-220 }\end{array}$ & $\begin{array}{l}6 \times 10^{10} \\
-8 \\
- \\
- \\
3 \times 10^{8} \\
8 \times 10^{-9}\end{array}$ & $\begin{array}{l}3 \times 10^{-10} \\
5 \times 10^{-13} \\
3 \times 10^{-12} \\
3 \times 10^{-10} \\
- \\
-\end{array}$ & $\begin{array}{l}2 \times 10^{11} \\
1 \times 10^{-12} \\
7 \times 10^{12} \\
= \\
=\end{array}$ & & \\
\hline & & & \multicolumn{4}{|c|}{$\begin{array}{l}\text { a } D, W \text {, and } X \text { represent lung retention classes; removal } \\
\text { half-times assigned to the compounds with classes } D, W \text {, } \\
\text { and } Y \text { are } 0.5,50 \text {, and } 500 \text { days, respectively. Exposure } \\
\text { conditions assume an inhalation rate of } 2,400 \mathrm{~m}^{3} \text { of air per } \\
\text { year (based on an exposure over } 40 \text { hours per week, } \\
50 \text { weeks per year). } \\
{ }^{b} \text { A hyphen means no limit has been established. }\end{array}$} & - & \\
\hline
\end{tabular}


TABLE A.2 (Cont'd)

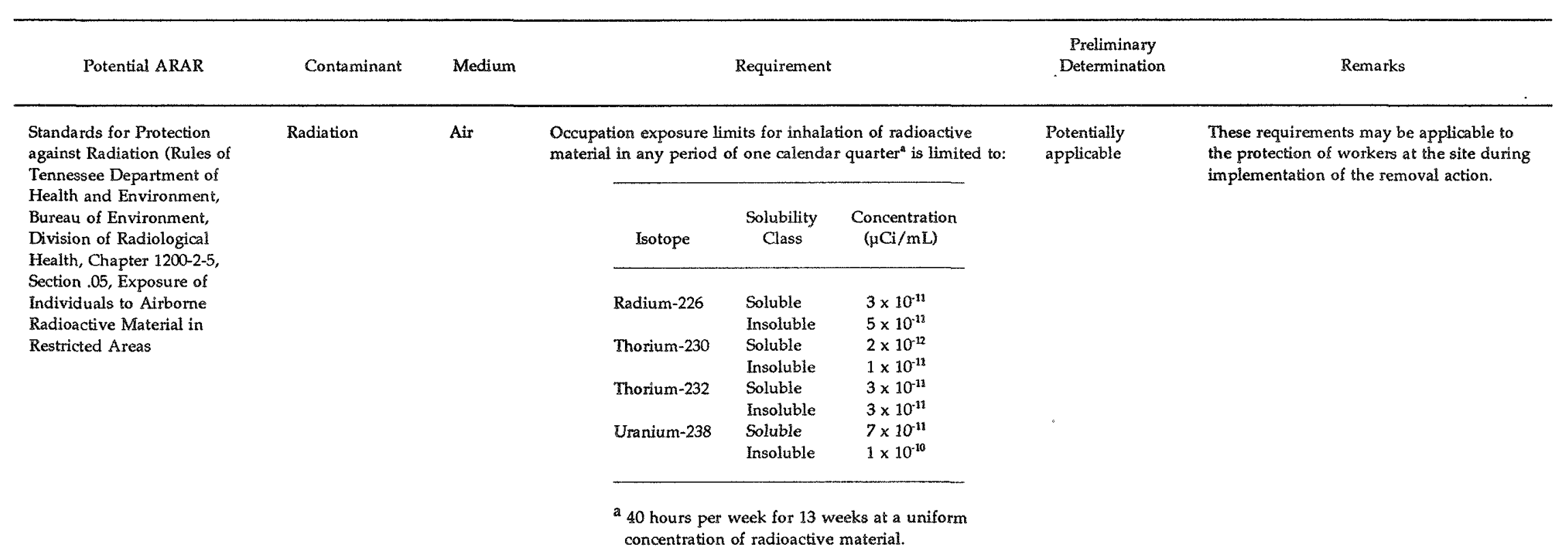




\section{TABLE A.2 (Cont'd)}

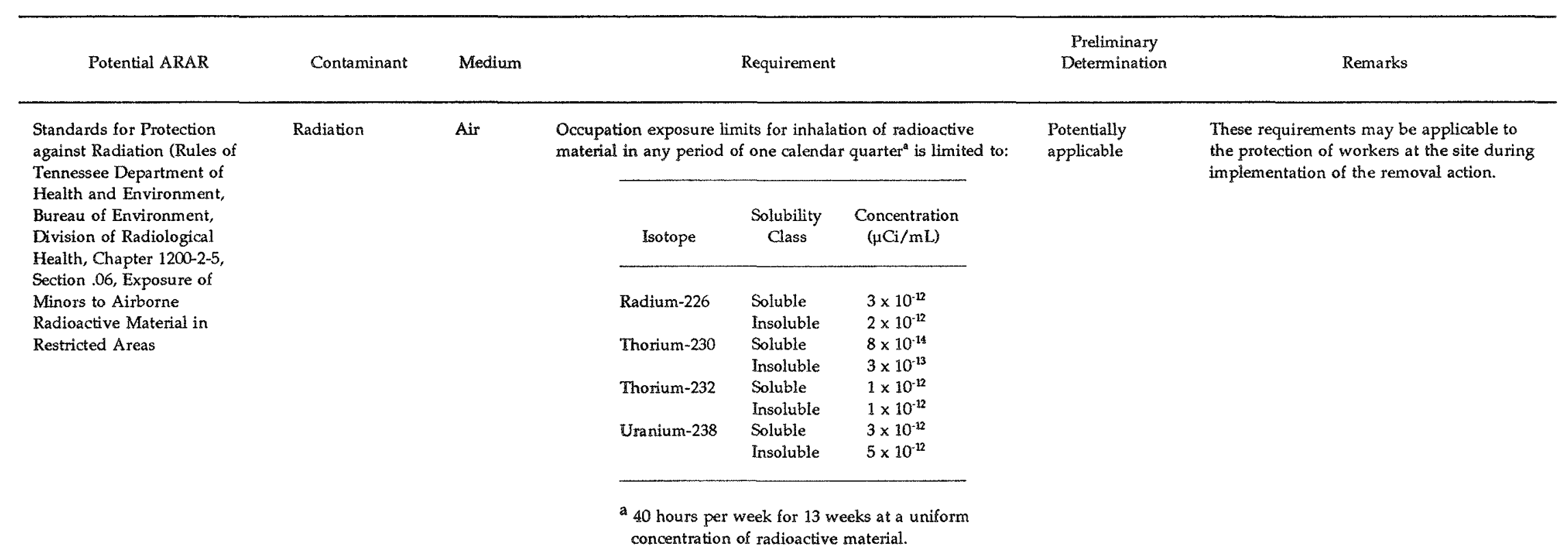


TABLE A.2 (Cont'd)

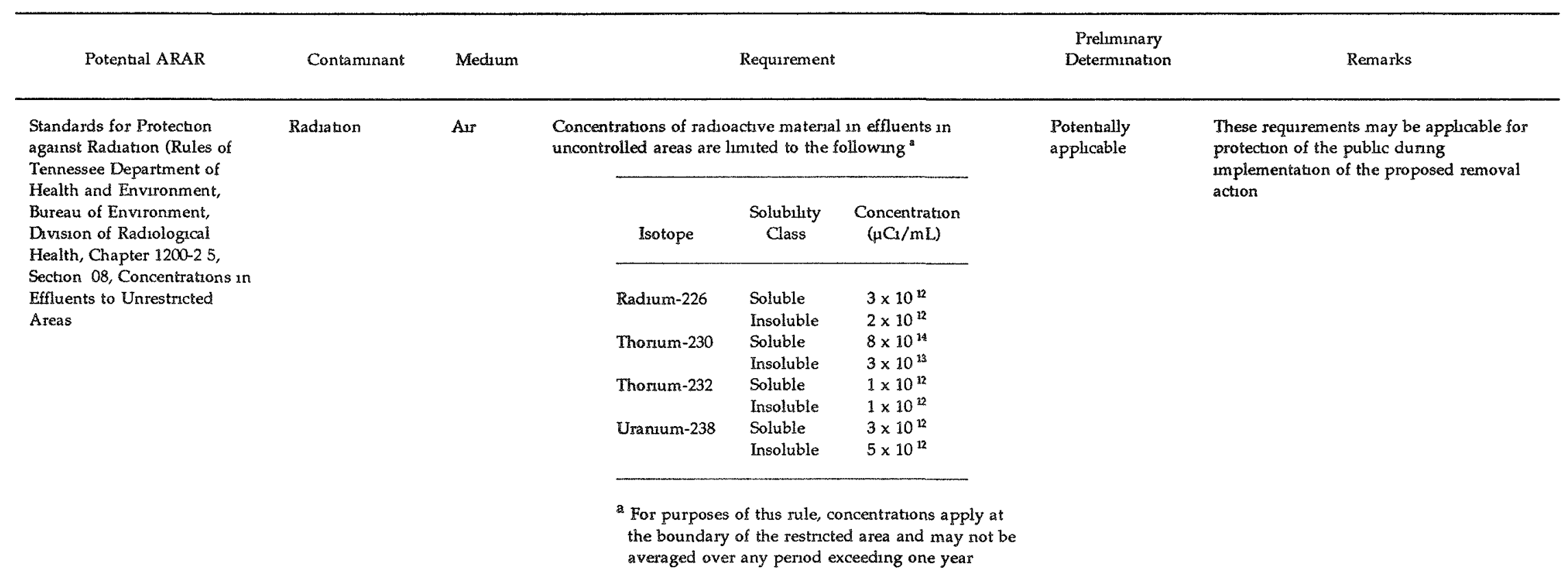




\section{TABLE A.2 (Cont'd)}

\begin{tabular}{|c|c|c|c|c|c|c|c|}
\hline Potential ARAR & Contaminant & Medium & & \multicolumn{2}{|c|}{ Requirement } & $\begin{array}{c}\text { Preliminary } \\
\text { Determination }\end{array}$ & Remarks \\
\hline \multirow[t]{4}{*}{$\begin{array}{l}\text { Occupational Safety and } \\
\text { Health Administration } \\
\text { Standards (29 CFR 1910; } \\
\text { 1910.1000), Subpart Z, Toxic } \\
\text { and Hazardous Substances }\end{array}$} & \multirow[t]{4}{*}{$\begin{array}{l}\text { Specific organic } \\
\text { and inorganic } \\
\text { substances }\end{array}$} & \multirow[t]{4}{*}{ Air } & \multicolumn{3}{|c|}{$\begin{array}{l}\text { Permissible occupational exposure limits for various airborne } \\
\text { substances have recently been revised to the following final } \\
\text { rule limits; they may be achieved by any reasonable } \\
\text { combination of engineering controls, work practices, and } \\
\text { personal protective equipment. }\end{array}$} & \multirow[t]{4}{*}{$\begin{array}{l}\text { Potentially } \\
\text { applicable }\end{array}$} & \multirow{4}{*}{$\begin{array}{l}\text { These requirements are part of an employee } \\
\text { protection law (rather than an } \\
\text { environmental law) with which all } \\
\text { CERCLA response actions should comply. } \\
\text { Because this compliance is directly } \\
\text { required, as promulgated in the NCP, these } \\
\text { requirements are not subject to evaluation } \\
\text { for attainment or waiver as part of the } \\
\text { ARAR process. However, they constitute } \\
\text { requirements for worker protection with } \\
\text { which the proposed action will comply. }\end{array}$} \\
\hline & & & Parameter & $\underset{\left(\mathrm{mg} / \mathrm{m}^{3}\right)}{\operatorname{Limit}}$ & Condition & & \\
\hline & & & $\begin{array}{l}\text { Aroclor } 1254 \\
\text { (PCB) }\end{array}$ & 0.5 & $\begin{array}{l}\text { Skin notation for } \\
\text { potential contribution } \\
\text { to overall exposure by } \\
\text { cutaneous route (airborne } \\
\text { or direct contact) }\end{array}$ & & \\
\hline & & & Lead & 0.05 & $\begin{array}{l}\text { For metallic lead and inorganic } \\
\text { compounds, as lead }\end{array}$ & & \\
\hline
\end{tabular}


TABLE A.2 (Cont'd)

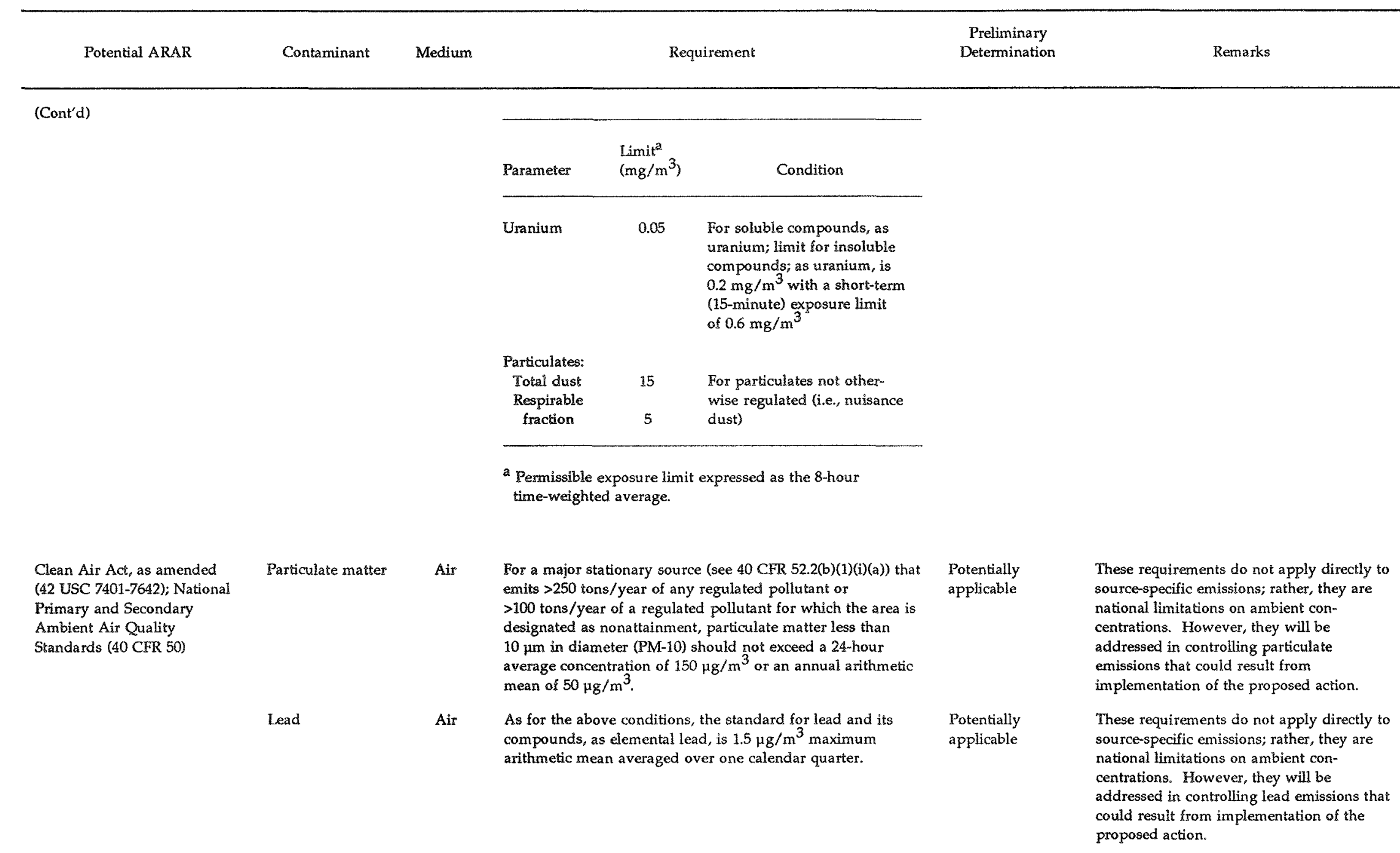

Clean Air Act, as amended Ambient Air Ouality Standards ( 40 CFR 50 )
Permissible exposure limit expressed as the 8-hou time-weighted average.

proposed action. 
TABLE A.2 (Cont'd)

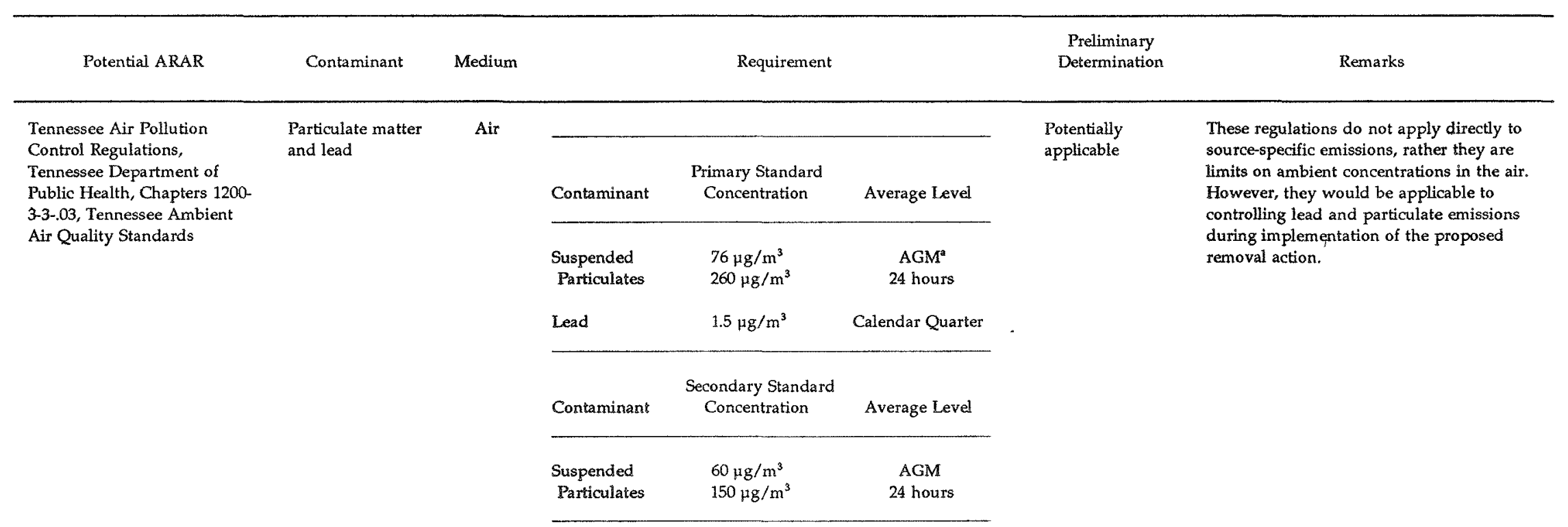

\begin{abstract}
Tennessee Air Pollution
Control Regulations,

Tennessee Department of

Public Health, Chapters 1200 -

3-8, Fugitive Dust

Toxic Substances Control Act.

as amended (15 USC 2607 .

2629; PL 94-469 et seq.);

Polychlorinated Biphenyls

(PCBs) Manufacturing,

Processing. Distribution in

Commerce, and Use

Prohibitions (40 CFR 761),

Subpart A, General
\end{abstract}

Particulate matter

Air

* AGM = Annual Geometric Mean

No person shall cause, suffer, allow, or permit any materials

to be handled, transported, or stored without taking

reasonable precautions to prevent particulate matter from

becoming airborne, including, but not limited to: water or

chemicals for control of dust in demolition, construction

operations, grading of roads, or clearing of land.

PCBs

Air

The release of inadvertently generated PCBs at the vent point

for emissions must be $<10 \mathrm{ppm}$.
Potentially applicable

Potentially relevant and appropriate
These regulations would be applicable to the excavation of soil and asphalt in the proposed action.

This requirement is not applicable because no PCBs would be generated and vented from manufacturing/processing activities as part of the proposed action; however, portions of this requirement may be relevant and appropriate because $\mathrm{PCB}$ emissions could occur during implementation. 


\section{TABLE A.2 (Cont'd)}

\begin{tabular}{|c|c|c|c|}
\hline Potential ARAR & Contaminant & Medium & Requirement \\
\hline $\begin{array}{l}\text { Occupational Safety and } \\
\text { Health Administration } \\
\text { Standards; Occupational } \\
\text { Health and Environmental } \\
\text { Control (29 CFR 1910; } \\
\text { 1910.95), Subpart G, } \\
\text { Occupational Noise Exposure }\end{array}$ & Noise & Air & $\begin{array}{l}\text { The permissible occupational exposure level for noise is } \\
90 \mathrm{dBA} \text { (slow response) for an 8-hour day; with decreasing } \\
\text { times of exposure, the levels increase to } 115 \mathrm{dBA} \text { per } \\
\text { 15-minute day. }\end{array}$ \\
\hline $\begin{array}{l}\text { Health and Environmental } \\
\text { Protection Standards for } \\
\text { Uranium and Thorium Mill } \\
\text { Tailings ( } 40 \text { CFR 192) }\end{array}$ & $\begin{array}{l}\text { Radium and } \\
\text { thorium }\end{array}$ & Soil & $\begin{array}{l}\text { Average concentrations of residual radioactive materials in } \\
\text { soil over an area of } 100 \mathrm{~m}^{2} \text { may not exceed background by } \\
\text { more than } 5 \mathrm{pCi} / \mathrm{g} \text { in the top } 15 \mathrm{~cm} \text { of soil or } 15 \mathrm{pCi} / \mathrm{g} \text { in } \\
\text { each } 15-\mathrm{cm} \text { layer below the top layer. }\end{array}$ \\
\hline $\begin{array}{l}\text { Radiation Protection of the } \\
\text { Public and the Environment } \\
\text { (DOE Order } 5400.5 \text { ) }\end{array}$ & $\begin{array}{l}\text { Radium and } \\
\text { thorium }\end{array}$ & Soil & $\begin{array}{l}\text { Average concentrations of radium-226, radium- }-228 \text {, thorium- } \\
230 \text {, and thorium- } 232 \text { averaged over an area of } 100 \mathrm{~m}^{2} \text { are } \\
5 \mathrm{pCi} / \mathrm{g} \text { in the top } 15 \mathrm{~cm} \text { of soil and } 15 \mathrm{pCl} / \mathrm{g} \text { in each } 15-\mathrm{cm} \\
\text { layer below the top layer. These guidelines take into account } \\
\text { ingrowth of radium- } 226 \text { from thorium- } 230 \text { and of radium- }-228 \\
\text { from thorium- } 230 \text {, and assume secular equilibrium. If both } \\
\text { thorium- } 230 \text { and radium- } 226 \text { or both thorium-232 and } \\
\text { radium- } 228 \text { are present and not in secular equilibrium, the } \\
\text { appropriate guideline is applied as a limit for the } \\
\text { radionuclide with the higher concentration. }\end{array}$ \\
\hline $\begin{array}{l}\text { Toxic Substances Control Act, } \\
\text { as amended (15 USC 2607- } \\
\text { 2629; PL 94-469 et seq.); } \\
\text { Polychlorinated Biphenyls } \\
\text { (PCBs) Manufacturing, } \\
\text { Processing, Distributton in } \\
\text { Commerce, and Use } \\
\text { Prohibitions (40 CFR 761), } \\
\text { Subpart G, PCB Spill Cleanup } \\
\text { Policy }\end{array}$ & PCBs & Soil & $\begin{array}{l}\text { For spills of materials contaminated with }>50 \mathrm{ppm} \text { PCBs in } \\
\text { unrestricted access areas (e.g., residential areas), soil within } \\
\text { the spill a rea must be excavated and backfilled with soil } \\
\text { containing < }<1 \mathrm{ppm} \text { PCBs. Contaminated soil may be } \\
\text { decontaminated to } 10 \mathrm{ppm} \text { by weight by excavating a } \\
\text { minimum of } 10 \text { inches and backsilling with soil containing } \\
<1 \text { ppm PCBs. For spills at outdoor electrical substations, the } \\
\text { soil must be cleaned to } 25 \mathrm{ppm} \text { by weight (as for other } \\
\text { restricted access areas) or to } 50 \mathrm{ppm} \text { by weight with posting } \\
\text { of visible notice. }\end{array}$ \\
\hline
\end{tabular}

Preliminary

Determination

Remarks

\section{Potentially applicable

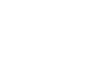 \\ Potentially relevant and \\ appropriate \\ These requirements are part of an employee protection law (rather than an CERCLA response actions should comply. Because this compliance is directly required, as promulgated in the NCP, these requirements are not subject to evaluation for attainment or waiver as part of the ARAR process. However, they constitute which the proposed action will comply. \\ The Elza Gate site is not a mill tailings site, so these requirements are not applicable; however, they may be considered relevant and appropriate to the proposed action.}

To be considered constitute requirements for protection of the public with which the proposed action will comply

Potentially relevant and appropriate
Although not promulgated standards, these
Any such spills at the site would have preceded the effective date of this requirement; hence, it is not applicable.

However, it may be considered relevant and appropriate to the proposed action. 
TABLE A.2 (Cont'd)

\begin{tabular}{|c|c|c|c|c|c|c|c|c|}
\hline Potential ARAR & Contaminant & Medium & & Requirem & & & $\begin{array}{l}\text { Preliminary } \\
\text { Determination }\end{array}$ & Remarks \\
\hline $\begin{array}{l}\text { Safe Drinkng Water Act } \\
\text { (42 USC 300G, PL 93-523), } \\
\text { National Primary Drinking } \\
\text { Water Regulations } \\
\text { (40 CFR 141), Subpart B, } \\
\text { Maximum Contaminant } \\
\text { Levels, Subpart G, National } \\
\text { Revised Primary Drinkng } \\
\text { Water Regulations Maximum } \\
\text { Contaminant Levels, National } \\
\text { Secondary Drinking Water } \\
\text { Regulations (40 CFR 143), } \\
\text { Secondary Maxumum } \\
\text { Contaminant Levels }\end{array}$ & See table & Water & $\begin{array}{l}\text { Radionucides } \\
\text { Gross alpha } \\
\text { Gross beta } \\
\text { Radium-226 and } \\
\text { radium-228 } \\
\text { Others } \\
\text { pH } \\
\text { TDS } \\
\text { a Including radiun } \\
\text { uranium } \\
\text { b As mrem/yr, an } \\
\text { beta activity exce } \\
\text { analysis and orga } \\
\text { should be made } \\
\text { limit is met }\end{array}$ & 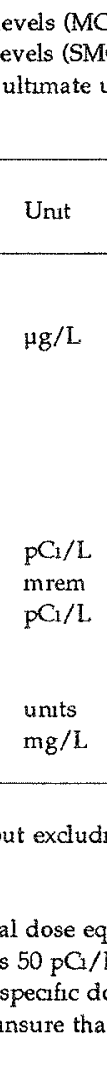 & $\begin{array}{l}\text { ivalent } \\
\text { 1sotop } \\
\text { e calcu } \\
\text { thus tot }\end{array}$ & $\begin{array}{l}- \\
\\
65-85 \\
500 \\
\text { and } \\
\text { gross } \\
\text { hons } \\
\text { dose }\end{array}$ & Not an ARAR & $\begin{array}{l}\text { These requirements are not applicable nos } \\
\text { relevant and appropriate because water } \\
\text { impacted by the site would not be used } \\
\text { directly as a drinking water supply } \\
\text { Further, ground water remediation is } \\
\text { outside the scope of this removal acton }\end{array}$ \\
\hline
\end{tabular}


TABLE A.2 (Cont'd)

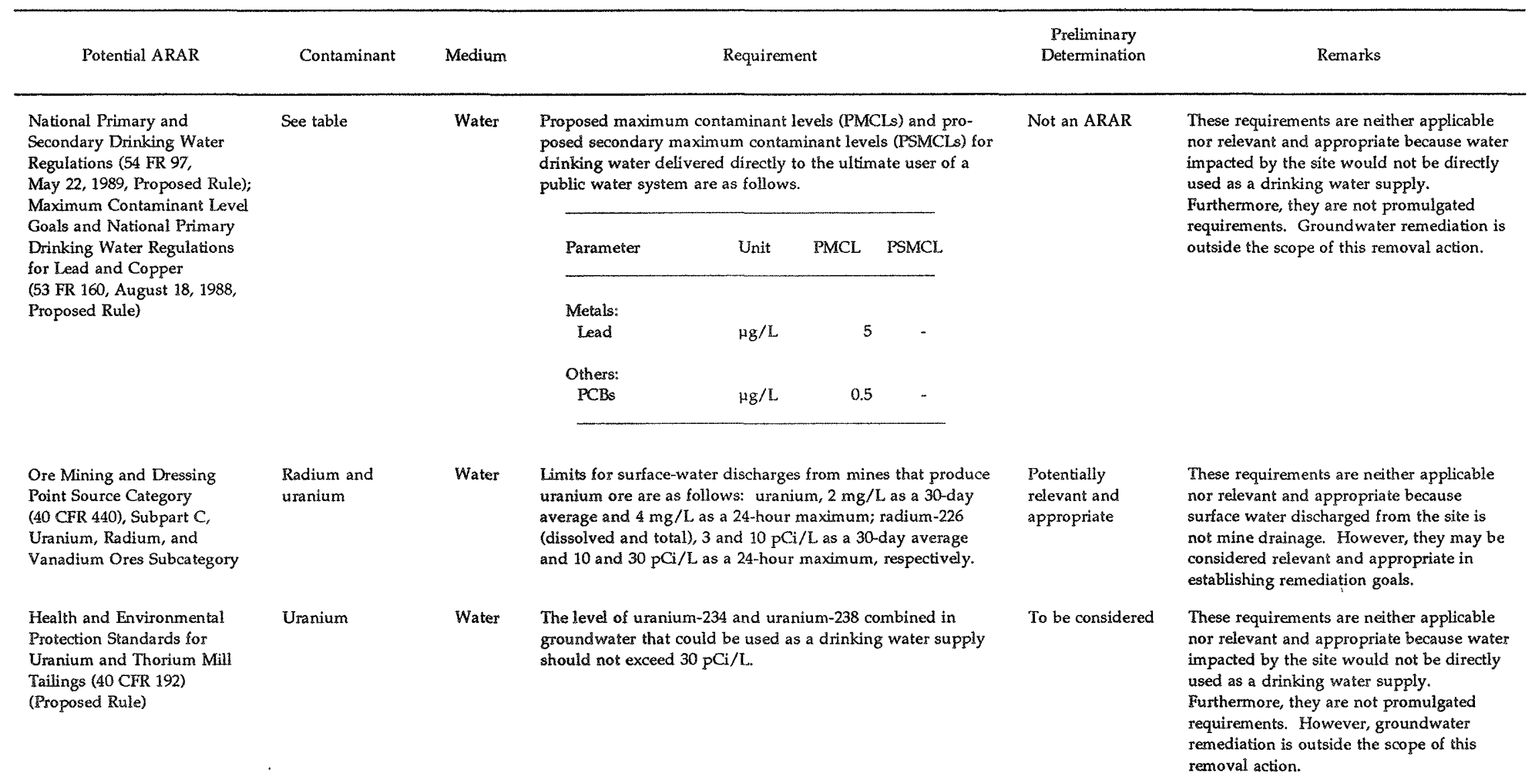


TABLE A.2 (Cont'd)

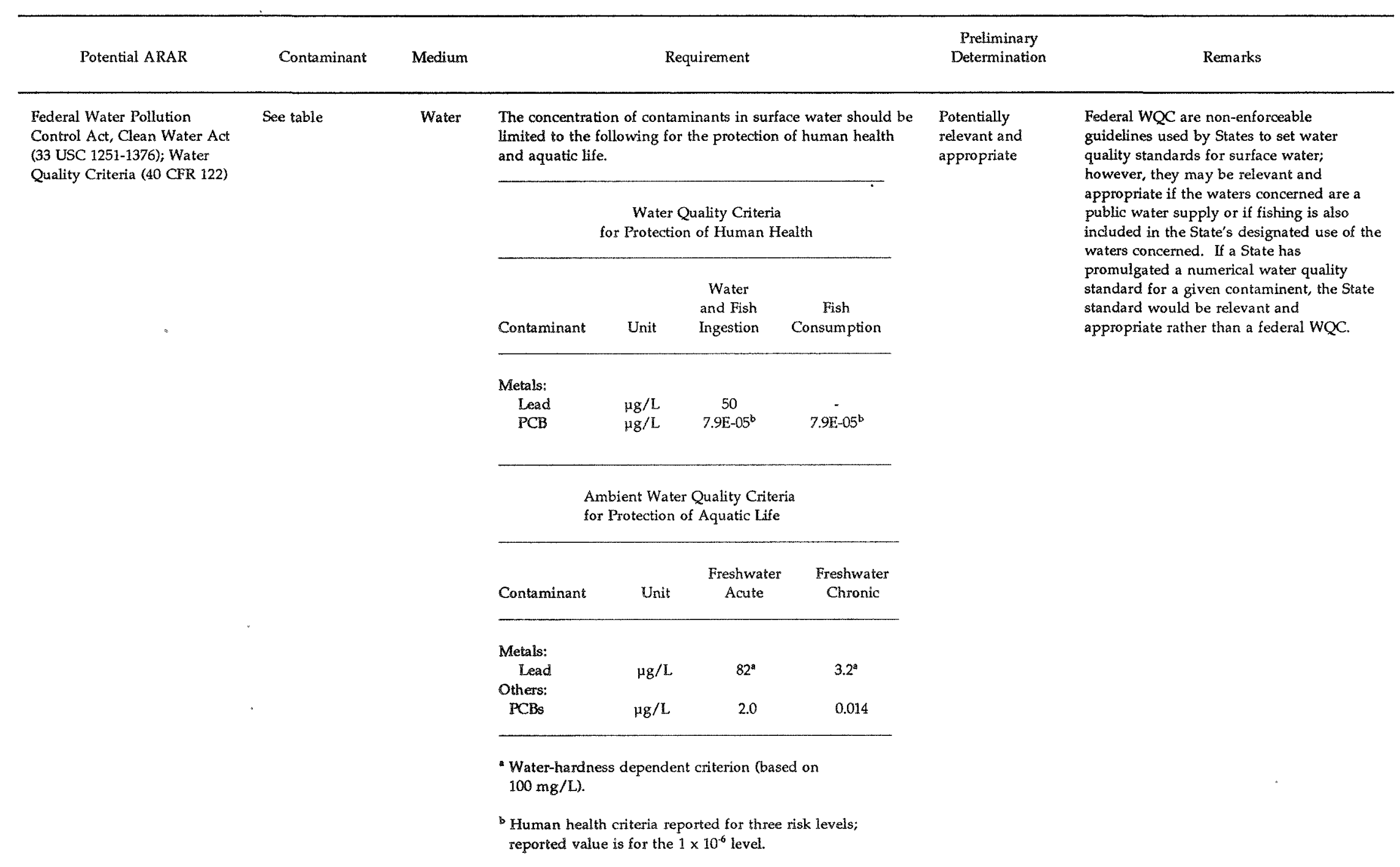




\section{TABLE A.2 (Cont'd)}

\begin{tabular}{|c|c|c|c|c|c|}
\hline Potential ARAR & Contaminant & Medium & Requirement & $\begin{array}{l}\text { Preliminary } \\
\text { Determination }\end{array}$ & Remarks \\
\hline $\begin{array}{l}\text { Tennessee Primary and } \\
\text { Secondary Drinking Water } \\
\text { Standards, Tennessee } \\
\text { Department of Health and } \\
\text { Environment, } \\
\text { Chapter } 1200-5-1\end{array}$ & See requirements & Water & $\begin{array}{l}\text { Tennessee has adopted the federal MCLs for public water } \\
\text { systems. Secondary drinking water regulations in Chapter } \\
1200-5-1-12 \text { are designed to ensure aesthetically pleasing } \\
\text { drinking water through community and noncommunity } \\
\text { water systems. }\end{array}$ & Not an ARAR & $\begin{array}{l}\text { These requirements are not applicable nor } \\
\text { relevant and appropriate because water } \\
\text { impacted by the site would not be used } \\
\text { direcity as a drinking water suply. Further, } \\
\text { groundwater remediation is outside the } \\
\text { scope of this removal action. }\end{array}$ \\
\hline $\begin{array}{l}\text { Tennessee Water Quality } \\
\text { Criteria, Tennessee } \\
\text { Department of Health, } \\
\text { Chapter } 1200-4-3.03 \text {, Criteria } \\
\text { for Water Conditions }\end{array}$ & See requirements & Water & $\begin{array}{l}\text { Standards for dissolved oxygen, } \mathrm{pH} \text {, hardness or mineral } \\
\text { compounds, total dissolved solids, solids, floating materials } \\
\text { and deposits, turbidity or color, temperature, coliform, taste } \\
\text { or odor, toxic substances, and other pollutants for domestic } \\
\text { and industrial water and for fish and aquatic life. Limits for } \\
\text { lead are set for domestic water at } 50 \mathrm{\mu g} / \mathrm{L} \text {. For fish and } \\
\text { aquatic life, toxic substances shall not adversely affect fish or } \\
\text { aquatic life and instream concentrations of toxic pollutants } \\
\text { shall not exceed } 1 / 10 \text { of the } 96 \text {-hour } \mathrm{LC}_{50} \text { based upon } \\
\text { available data using one or more of the most sensitive } \\
\text { organisms significant to the aquatic community of the waters }\end{array}$ & $\begin{array}{l}\text { Potentially } \\
\text { applicable }\end{array}$ & $\begin{array}{l}\text { These requirements would be applicable to } \\
\text { any discharge of contaminants into the } \\
\text { surface waters of the state during } \\
\text { implementation of the proposed removal } \\
\text { action. Further, the Tennessee Department } \\
\text { of Health and Environment has proposed } \\
\text { changes to the criteria to include protection } \\
\text { of recreational uses, when promulgated, } \\
\text { these criteria may also be applicable to } \\
\text { surface-water discharges. }\end{array}$ \\
\hline
\end{tabular}

Tennessee Effluent

Limitations and Standards,

Tennessee Water Quality

Control Board,

Chapter $1200-4-5$
See requirements Water under consideration. References to be used in determining
toxicity limitations shall include, but not be limited to federal regulations under Section 307 of the Clean Water Act and federal regulations under Section 1412 of the Public Health Service Act as amended by the Safe Drinking Water Act.

These regulations adopt the federal effluent limits under $\$ \S$ $301,302,306$, and 307 of the Clean Water Act. In the absence of Federal guidelines, industrial wastewater treatment units are required to achieve daily maximum concentrations of lead not to exceed $0.1 \mathrm{mg} / \mathrm{L}$, suspended solids not to exceed $40 \mathrm{mg} / \mathrm{L}$, and settleable solids not to exceed $.05 \mathrm{~mL} / \mathrm{L}$.
Potentially relevant and applicable

These effluent limitations are not applicable to the Elza Gate site because it does not have a wastewater treatment facility, but the limitations may be relevant an applicable for any discharge of contaminents to the surface waters of the state during implementation of the proposed action. 


\section{TABLE A.2 (Cont'd)}

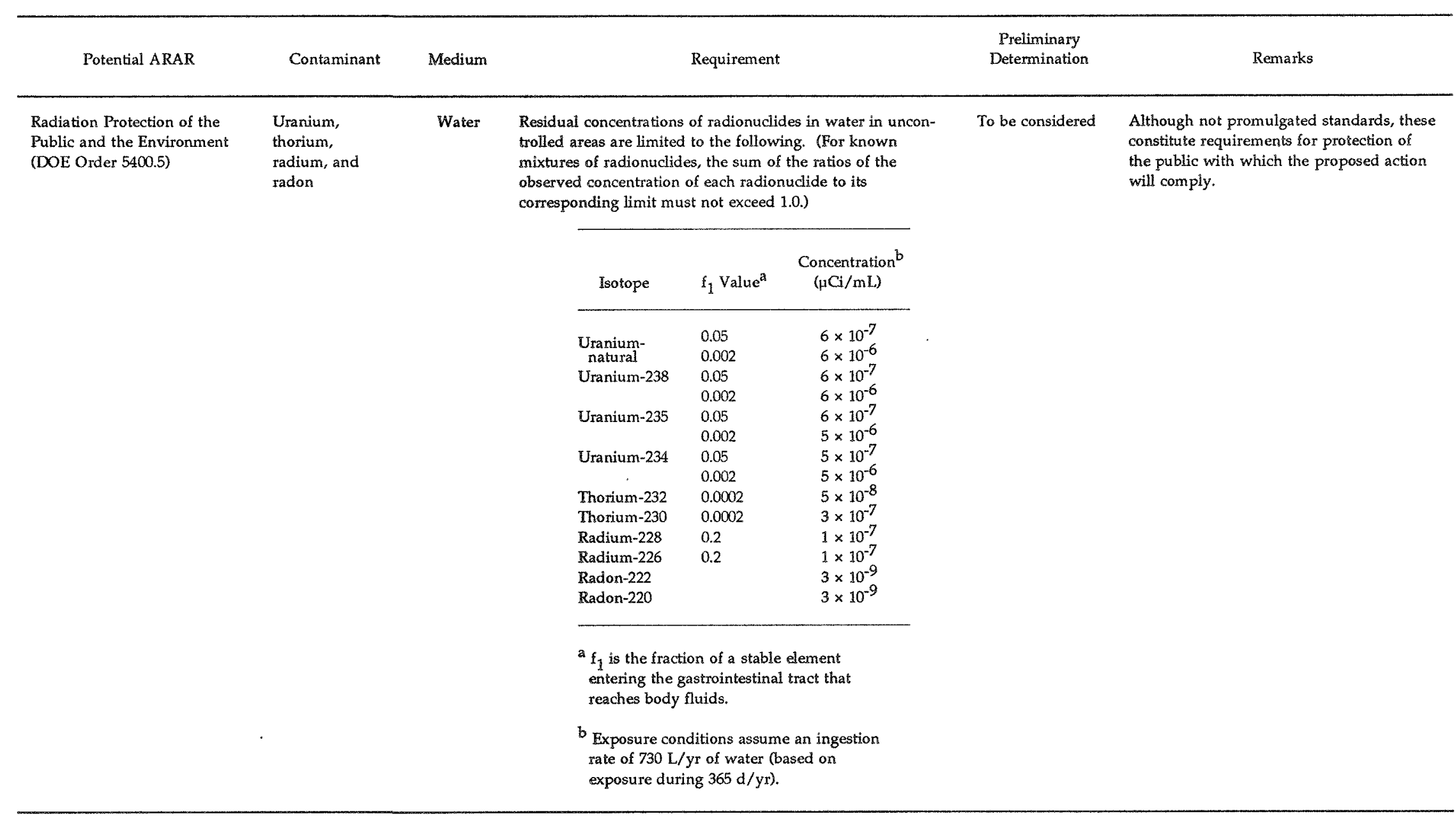


TABLE A.3 Potential Action-Specific Requirements

\begin{tabular}{|c|c|c|c|c|}
\hline Potential ARAR & Action & Requirement & $\begin{array}{l}\text { Preliminary } \\
\text { Determination }\end{array}$ & Remarks \\
\hline $\begin{array}{l}\text { Hazardous Material } \\
\text { Transportation Act, as amended } \\
\text { (49 USC 1801-1812); Solid Wastes } \\
\text { (40 CFR 263), Standards } \\
\text { Applicable to Transportation of } \\
\text { Hazardous Waste }\end{array}$ & Transportation & $\begin{array}{l}\text { Generic requirements are established for minimizing the } \\
\text { environmental impacts of spills or releases of hazardous materials, as } \\
\text { are procedures for transporting hazardous waste. }\end{array}$ & $\begin{array}{l}\text { Potentially } \\
\text { applicable }\end{array}$ & $\begin{array}{l}\text { These requirements are not part of an } \\
\text { environmental law and hence are not } \\
\text { subject to evaluation for attainment or } \\
\text { waiver as part of the ARAR process. } \\
\text { However, they could be pertinent to the } \\
\text { proposed action if hazardous waste is } \\
\text { transported off-site. In this case, the } \\
\text { pertinent requirements (e.g., for spill } \\
\text { response) would be addressed during } \\
\text { implementation. }\end{array}$ \\
\hline $\begin{array}{l}\text { Hazardous Materials } \\
\text { Regulations; Shippers -- General } \\
\text { Requirements for Shipments and } \\
\text { Packagings ( } 49 \text { CFR 173), } \\
\text { Subpart I, Radioactive Materials }\end{array}$ & Transportation & $\begin{array}{l}\text { Low-specific-activity radioactivity materials must be packaged in } \\
\text { strong, tight containers to prevent leakage of radioactivity under } \\
\text { conditions normally incident to transportation, and the vehicles must } \\
\text { be placarded. In exclusive-use vehicles, external radiation levels on } \\
\text { packages must be }<200 \mathrm{mrem} / \mathrm{h} \text {, or }<1,000 \mathrm{mrem} / \mathrm{h} \text { if secured in a } \\
\text { closed transport vehicle with no intermediate loading or unloading; } \\
\text { external radiation levels on the outer surface of the vehicle are limited } \\
\text { to }<200 \mathrm{mrem} / \mathrm{h} \text { at any point and }<10 \mathrm{mrem} / \mathrm{h} \text { at } 2 \mathrm{~m} \text { from the } \\
\text { surface of the vehicle; and levels in any normally occupied space are } \\
\text { limited to }<2 \mathrm{mrem} / \mathrm{h} \text {. }\end{array}$ & $\begin{array}{l}\text { Potentially } \\
\text { applciable }\end{array}$ & $\begin{array}{l}\text { These requirements are not part of an } \\
\text { environmental law and hence are not } \\
\text { subject to evaluation for attainment or } \\
\text { waiver as part of the ARAR process. } \\
\text { However, they could be pertinent to the } \\
\text { proposed action if the waste is } \\
\text { transported off-site because the average } \\
\text { concentration of radionuclides in certain } \\
\text { waste could meet the criteria for } \\
\text { classification as low-specific-activity } \\
\text { material. }\end{array}$ \\
\hline $\begin{array}{l}\text { Noise Control Act, as Amended; } \\
\text { Noise Pollution and Abatement } \\
\text { Act }\end{array}$ & $\begin{array}{l}\text { Decontamina- } \\
\text { tion }\end{array}$ & $\begin{array}{l}\text { The public must be protected from noises (e.g., that could result from } \\
\text { remedial action activities) that jeopardize health or welfare. }\end{array}$ & $\begin{array}{l}\text { Potentially } \\
\text { applicable }\end{array}$ & $\begin{array}{l}\text { Because equipment and vehicles would } \\
\text { be involved in certain aspects of the } \\
\text { proposed action, all pertinent } \\
\text { requirements of the act would be } \\
\text { followed. }\end{array}$ \\
\hline
\end{tabular}


TABLE A.3 (Cont'd)

\begin{tabular}{|c|c|c|c|c|}
\hline Potential ARAR & Action & Requirement & $\begin{array}{l}\text { Preliminary } \\
\text { Determination }\end{array}$ & Remarks \\
\hline $\begin{array}{l}\text { Termination of Operating } \\
\text { Licenses for Nuclear Reactors } \\
\text { (U.S. Nuclear Regulatory } \\
\text { Commission Regulatory } \\
\text { Guide 1.86) }\end{array}$ & $\begin{array}{l}\text { Decontamina- } \\
\text { tion }\end{array}$ & $\begin{array}{l}\text { Structural debris associated with licensed reactors that is released for } \\
\text { reuse without radiological restrictions shall be decontaminated to the } \\
\text { specified levels. }\end{array}$ & $\begin{array}{l}\text { Potentially } \\
\text { relevant and } \\
\text { appropriate }\end{array}$ & $\begin{array}{l}\text { These requirements are not applicable } \\
\text { because the Elza Gate site is not a } \\
\text { nuclear reactor licensed by the U.S. } \\
\text { Nuclear Regulatory Commission. } \\
\text { Furthermore, they have been } \\
\text { incorporated into DOE Order } 5400.5 \text {, } \\
\text { with which the proposed action will } \\
\text { comply; however, this order does not } \\
\text { include the requirements shown here. } \\
\text { These requirements may be relevant } \\
\text { and appropriate to the release of } \\
\text { structural material for reuse without } \\
\text { radiological restrictions. }\end{array}$ \\
\hline $\begin{array}{l}\text { Radiation Protection of the } \\
\text { Public and the Environment } \\
\text { (DOE Order 5400.5) }\end{array}$ & $\begin{array}{l}\text { Decontamina- } \\
\text { tion }\end{array}$ & $\begin{array}{l}\text { Structural debris that is released from DOE facilities for reuse without } \\
\text { radiological restrictions shall be decontaminated to specified levels. }\end{array}$ & $\begin{array}{l}\text { To be } \\
\text { considered }\end{array}$ & $\begin{array}{l}\text { These requirements are not pertinent } \\
\text { because structural debris decontamina- } \\
\text { tion is outside the scope of the } \\
\text { proposed removal action. All } \\
\text { contaminated debris will be removed to } \\
\text { DOE's Oak Ridge Reservation and only } \\
\text { uncontaminated structural debris will } \\
\text { remain on-site. }\end{array}$ \\
\hline $\begin{array}{l}\text { Occupational Safety and Health } \\
\text { Administration Standards for } \\
\text { Hazardous Waste Operations } \\
\text { and Emergency Response } \\
\text { (29 CFR 1910) }\end{array}$ & $\begin{array}{l}\text { Waste } \\
\text { management }\end{array}$ & $\begin{array}{l}\text { General worker protection requirements are established, as are } \\
\text { requirements for worker training and the development of an } \\
\text { emergency response plan and a safety and health program for } \\
\text { employees. In addition, procedures are established for hazardous } \\
\text { waste operations -- induding decontamination and drum/container } \\
\text { handling (e.g., for radioactive waste, asbestos, and PCBs). }\end{array}$ & $\begin{array}{l}\text { Potentially } \\
\text { applicable }\end{array}$ & $\begin{array}{l}\text { These requirements are part of an } \\
\text { employee protection law (rather than an } \\
\text { environmental law) with which all } \\
\text { CERCLA response actions should } \\
\text { comply. Because this compliance is } \\
\text { directly required, as promulgated in the } \\
\text { NCP, these requirements are not subject } \\
\text { to evaluation for attainment or waiver } \\
\text { as part of the ARAR process. However, } \\
\text { they constitute requirements for worker } \\
\text { protection with which the proposed } \\
\text { action will comply. }\end{array}$ \\
\hline
\end{tabular}


TABLE A.3 (Cont'd)

\begin{tabular}{|c|c|c|c|c|}
\hline Potential ARAR & Action & Requirement & $\begin{array}{l}\text { Preliminary } \\
\text { Determination }\end{array}$ & Remarks \\
\hline $\begin{array}{l}\text { Radioactive Waste Management } \\
\text { (DOE Order } 5820.2 \mathrm{~A} \text { ) }\end{array}$ & $\begin{array}{l}\text { Waste } \\
\text { management }\end{array}$ & $\begin{array}{l}\text { External exposure to radioactive waste (including releases) should not } \\
\text { result in an effective dose equivalent of }>25 \mathrm{mrem} / \mathrm{yr} \text { to any member } \\
\text { of the public; releases to the atmosphere are to meet the requirements } \\
\text { of } 40 \text { CFR } 61 \text { (see related discussion in Table A. } 2 \text { for contaminant- } \\
\text { specific requirements); and an environmental monitoring program } \\
\text { must be implemented to address compliance with performance } \\
\text { standards. }\end{array}$ & $\begin{array}{l}\text { To be } \\
\text { considered }\end{array}$ & $\begin{array}{l}\text { Although not promulgated standards, } \\
\text { these constitute requirements with } \\
\text { which the proposed action will comply. }\end{array}$ \\
\hline $\begin{array}{l}\text { Radiation Protection of the } \\
\text { Public and the Environment } \\
\text { (DOE Order 5400.5) }\end{array}$ & $\begin{array}{l}\text { Interim waste } \\
\text { storage and } \\
\text { management }\end{array}$ & $\begin{array}{l}\text { The control and stabilization features of a storage facility for waste } \\
\text { containing uranium, thorium, and their decay products should be } \\
\text { designed to ensure an effective life of } 50 \text { years, with a minimum life } \\
\text { of at least } 25 \text { years, to the extent reasonably achievable; site access } \\
\text { controls should be designed to ensure an effective life of at least } \\
25 \text { years, to the extent reasonable; and periodic monitoring, shielding, } \\
\text { access restrictions, and safety measures must be implemented to } \\
\text { control the migration of radioactive material, as appropriate. }\end{array}$ & $\begin{array}{l}\text { To be } \\
\text { considered }\end{array}$ & $\begin{array}{l}\text { Although not promulgated standards, } \\
\text { these constitute requirements for storage } \\
\text { and management of wastes with which } \\
\text { this action will comply. }\end{array}$ \\
\hline $\begin{array}{l}\text { Health and Environmental } \\
\text { Protection Standards for } \\
\text { Uranium and Thorium Mill } \\
\text { Tailings (40 CFR 192) }\end{array}$ & Waste disposal & $\begin{array}{l}\text { Uranium mill tailings shall be disposed of in a manner to ensure } \\
\text { effective control for up to } 1,000 \text { years to the extent reasonably } \\
\text { achievable, and in any case for up to } 200 \text { years; controls must provide } \\
\text { that radon-222 releases from disposal facilities to the atmosphere will } \\
\text { not exceed an annual release rate of } 20 \mathrm{pCi} / \mathrm{m}^{2} \text {-s or increase the } \\
\text { annual average concentration of radon- } 222 \text { in air at or above any } \\
\text { location outside the disposal site by more than } 0.5 \mathrm{pCi} / \mathrm{L} \text {. }\end{array}$ & Not an ARAR & $\begin{array}{l}\text { The Elza Gate site is not a mill tailings } \\
\text { site, so these requirements are not } \\
\text { applicable. Further, they are not } \\
\text { relevant and appropriate because a } \\
\text { disposal facility is outside the scope of } \\
\text { the proposed removal action. }\end{array}$ \\
\hline $\begin{array}{l}\text { Atomic Energy Act, as amended } \\
\text { (42 USC 2112) }\end{array}$ & Waste disposal & $\begin{array}{l}\text { The DOE can distribute byproduct material only to individuals or } \\
\text { organizations who are licensed by the U.S. Nuclear Regulatory } \\
\text { Commission to receive such material. }\end{array}$ & $\begin{array}{l}\text { Potentially } \\
\text { applicable }\end{array}$ & $\begin{array}{l}\text { These requirements may be applicable } \\
\text { to the disposal of radioactively } \\
\text { contaminated material (which is } \\
\text { byproduct material) from the Elza Gate } \\
\text { site at commercial facilities. }\end{array}$ \\
\hline
\end{tabular}

Health and Environmental Protection Standards for Uranium and Thorium M ailings (40 CFR 192)

Atomic Energy Act, as amended (42 USC 2112)
The DOE can distribute byproduct material only to individuals or
organizations who are licensed by the U.S. Nuclear Regulatory Commission to receive such material. 
TABLE A.3 (Cont'd)

\begin{tabular}{|c|c|c|c|c|}
\hline Potentral ARAR & Action & Requirement & $\begin{array}{l}\text { Preluminary } \\
\text { Defermination }\end{array}$ & Remarks \\
\hline $\begin{array}{l}\text { Radroactuve Waste Management } \\
\text { (DOE Order } 58202 \mathrm{~A} \text { ) }\end{array}$ & Waste disposal & 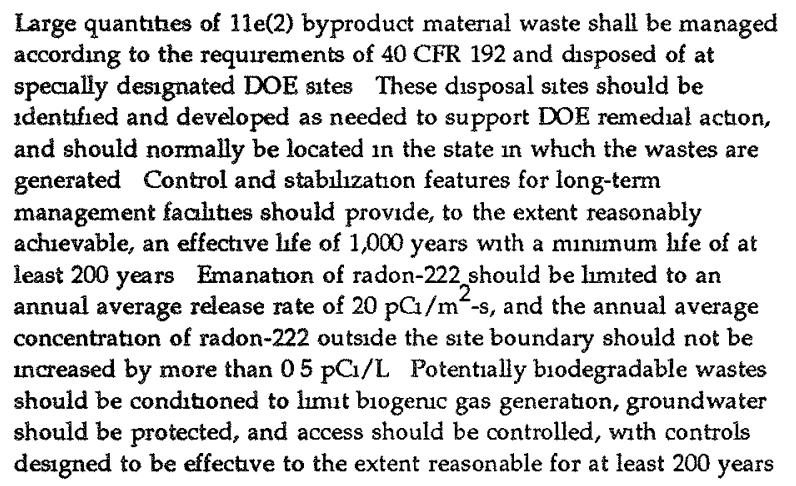 & $\begin{array}{l}\text { To be } \\
\text { considered }\end{array}$ & $\begin{array}{l}\text { Although not promulgated standards, } \\
\text { these consttute requirements with } \\
\text { which the proposed action will comply }\end{array}$ \\
\hline $\begin{array}{l}\text { Toxic Substances Control Act, as } \\
\text { amended (15 USC 2607-2629, } \\
\text { PL } 94-469 \text { et seq) } \\
\text { Polychlorinated Biphenyls } \\
\text { (PCBs) Manufacturng, } \\
\text { Processing, Distribution in } \\
\text { Commerce, and Use Prohibitions } \\
\text { (40 CFR 761), Subpart A, } \\
\text { General }\end{array}$ & PCB testıng & $\begin{array}{l}\text { Inspection and testing are required for materral contaminated with } \\
\text { PCBs }\end{array}$ & $\begin{array}{l}\text { Potentrally } \\
\text { applicable }\end{array}$ & $\begin{array}{l}\text { Thus requirement may be apphicable to } \\
\text { characterzation of site waste for PCBS } \\
\text { Such characterzation has previously } \\
\text { been conducted as part of an interm } \\
\text { response action for the project }\end{array}$ \\
\hline $\begin{array}{l}\text { Toxic Substances Control Act, as } \\
\text { amended (15 USC } 26072629 \text {, } \\
\text { PL } 94-499 \text {, et seq), } \\
\text { Polychlorinated Biphenyls } \\
\text { (PCBs) Manufacturing, } \\
\text { Processing, Distribution in } \\
\text { Commerce, and Use Prohbitions }\end{array}$ & PCB storage & $\begin{array}{l}\text { Maternal contaminated with PCBs }>50 \text { ppm must be stored for } \\
\text { disposal (within one year) in a facilty that is marked for storage and } \\
\text { is not located in a 100-year floodplain The facilty should have a roof } \\
\text { and walls to prevent rann from reaching the stored PCBs and an } \\
\text { impervious floor with 6-inch curbing to provide a double containment } \\
\text { volume Stored articles or contaners should be checked monthly for } \\
\text { leaks }\end{array}$ & $\begin{array}{l}\text { Potentally } \\
\text { apphcable }\end{array}$ & $\begin{array}{l}\text { Storage of articles or containers with } \\
\text { PCB concentrations in excess of } 50 \mathrm{ppm} \\
\text { may be part of the proposed action, if } \\
\text { such materal were present and required } \\
\text { storage, the requirement would be } \\
\text { applicable }\end{array}$ \\
\hline
\end{tabular}




\section{TABLE A.3 (Cont'd)}

\begin{tabular}{|c|c|c|c|c|}
\hline Potential ARAR & Action & Requirement & $\begin{array}{l}\text { Preliminary } \\
\text { Determination }\end{array}$ & Remarks \\
\hline $\begin{array}{l}\text { Toxic Substances Control Act, as } \\
\text { amended (15 USC } 2607-2629 ; \\
\text { PL } 94-499 \text {, et seq.); } \\
\text { Polychlorinated Biphenyls } \\
\text { (PCBs) Manufacturing, } \\
\text { Processing, Distribution in } \\
\text { Commerce, and Use Prohibitions } \\
\text { (40 CFR 761), Subpart D, Storage } \\
\text { and Disposal }\end{array}$ & $\begin{array}{l}\text { PCB } \\
\text { incineration }\end{array}$ & $\begin{array}{l}\text { Liquid PCBs should be incinerated in an EPA-approved facility either } \\
\text { for } 2 \text { seconds at } 1200^{\circ} \mathrm{C} \text { with } 3 \% \text { excess oxygen in the stack gas or } \\
\text { for } 3 \text { seconds at } 1600^{\circ} \mathrm{C} \text { with } 2 \% \text { excess oxygen; the combustion } \\
\text { efficiency should be } 99.9 \% \text {, and water scrubbers should be used to } \\
\text { control hydrochloric acid (HC). Nonliquid PCBs should be } \\
\text { incinerated in an EPA-approved facility with the same combustion } \\
\text { efficiency, and mass emissions should not exceed } 0.001 \mathrm{~g} / \mathrm{kg} \mathrm{PCB} \\
\text { introduced. }\end{array}$ & Not an ARAR & $\begin{array}{l}\text { These requirements are not applicable } \\
\text { because treatment of material from the } \\
\text { site that is contaminated with PCBs is } \\
\text { outside the scope of the proposed } \\
\text { removal action. }\end{array}$ \\
\hline $\begin{array}{l}\text { Toxic Substances Control Act, as } \\
\text { amended (15 USC 26070-2629; } \\
\text { PL 94-499, et seq.); } \\
\text { Polychlorinated Biphenyls } \\
\text { (PCBs) Manufacturing, } \\
\text { Processing, Distribution in } \\
\text { Commerce, and Use Prohibitions } \\
\text { (40 CFR 761), Subpart D, Storage } \\
\text { and Disposal }\end{array}$ & PCB disposal & $\begin{array}{l}\text { Material contaminated with PCBs }>50 \mathrm{ppm} \text { must be incinerated or } \\
\text { disposed of in a chemical waste landfill. PCB containers for PCBs } \\
<500 \mathrm{ppm} \text { may be disposed of as municipal solid waste after draining } \\
\text { the free liquids; liquids containing }<500 \mathrm{ppm} \text { PCB can be disposed of } \\
\text { in a chemical waste landfill if it is not an ignitable waste. PCB articles } \\
\text { with } \geq 500 \text { ppm PCBs and nonliquid material with }>50 \mathrm{ppm} \text { PCBs (e.g., } \\
\text { contaminated soil, rags, or other debris) should be disposed of by } \\
\text { incinerating (or using an alternative treatment) or landfilling. The } \\
\text { chemical waste landfill should be located in an area with an in-place } \\
\text { soil thickness of } 4 \text { feet or compacted thickness of } 3 \text { feet and a soil } \\
\text { permeability of } \leq 10^{-7} \mathrm{~cm} / \mathrm{sec},>30 \% \text { passing through a No. } 200 \text { sieve, } \\
\text { a liquid limit }>30 \text {, and a plasticity index }>15 \text {; a synthetic liner can be } \\
\text { used to achieve an equivalent permeability. The landfill should also } \\
\text { contain a leachate collection system, which can be a simple gravity- } \\
\text { flow drainfield, a compound system (where a double liner is present), } \\
\text { or a suction lysimeter network. The bottom of the landfill should be } \\
250 \text { feet above the historical high groundwater table, and the site } \\
\text { should not be hydrologically connected to standing or flowing water. } \\
\text { Structures should be in place to divert runoff from a } 24 \text {-hour, } 25-y e a r \\
\text { storm. If located below the } 100-y e a r \text { floodwater elevation, } 2 \text {-foot } \\
\text { surface water diversion dikes should surround the landfill. The } \\
\text { landfill should be located in an area of low to moderate relief to } \\
\text { minimize erosion, landslides, and slumping. Surface water and the } \\
\text { leachate collection system should be monitored (monthly during } \\
\text { operations, then twice a year for surface water), as should } \\
\text { groundwater. }\end{array}$ & $\begin{array}{l}\text { Potentially } \\
\text { applicable }\end{array}$ & $\begin{array}{l}\text { Disposal of a small amount of material, } \\
\text { which may be contaminated with PCBs } \\
>50 \mathrm{ppm} \text { will be part of the proposed } \\
\text { action; if such material is present, the } \\
\text { requirement may be applicable. }\end{array}$ \\
\hline
\end{tabular}




\section{TABLE A.3 (Cont'd)}

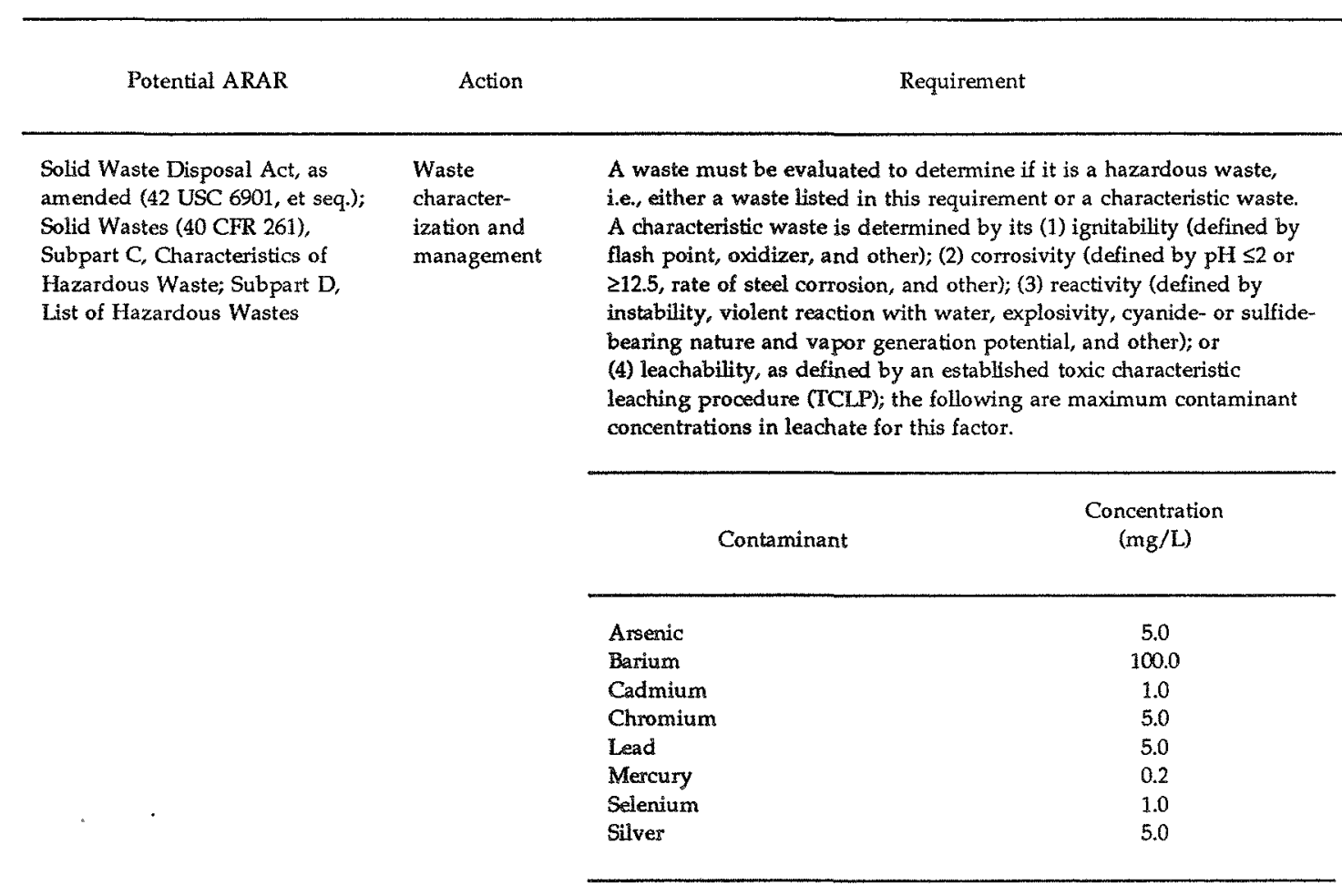

Preliminary

Determination

Remarks

Solid Waste Disposal Act, as amended (42 USC 6901, et seq. Solid Wastes (40 CFR 264) Subpart B, General Facility Standards, Subpart $C$

Preparedness and Prevention Subpart D, Contingency Plan and Emergency Procedures; Subpart E, Manifest System, Recordkeeping and Reporting;
Waste treatment, storage, and disposal

General requirements are established for storage, treatment and disposal facility location, design and inspection, waste compatibility determination, emergency contingency plans, preparedness plans, recordkeeping, reporting and worker training. Location requirements include (1) facilities must not be located within $61 \mathrm{~m}$ (200 ft) of a fault in which displacement has occurred in Holocene time (i.e., since the end of the Pleistocene) and (2) facilities located in a 100-year floodplain must be constructed, operated, and maintained to prevent washout of any hazardous waste by a 100-year flood.
Potentially applicable

This requirement is applicable to the characterization and management of site waste; this waste has been evaluated to determine whether the prerequisites for definition as hazardous waste are met. Only lead was identified as a potential RCRA characteristic or listed waste for the Elza Gate site, but subsequent testing under the TCLP determined that lead did not meet the maximum contaminant concentration; therefore, the waste is not hazardous under RCRA.

These requirements are not applicable because storage, treatment or disposal, as defined under RCRA, is outside the scope of the proposed action, even if any site waste meets the prerequisites for definition as characteristic hazardous waste. 


\section{TABLE A.3 (Cont'd)}

\begin{tabular}{|c|c|c|c|c|}
\hline Potential ARAR & Action & Requirement & $\begin{array}{l}\text { Preliminary } \\
\text { Determination }\end{array}$ & Remarks \\
\hline $\begin{array}{l}\text { Solid Waste Disposal Act, as } \\
\text { amended ( } 42 \text { USC } 6901 \text {, et seq.); } \\
\text { Solid Wastes ( } 40 \text { CFR 264), } \\
\text { Subpart F, Releases from Solid } \\
\text { Waste Management Units }\end{array}$ & Waste disposal & $\begin{array}{l}\text { A groundwater monitoring system must be maintained for a solid } \\
\text { waste management unit such as a surface impoundment, waste pile, } \\
\text { land treatment unit, or landfill. An exemption to continued } \\
\text { maintenance of this system during the post-closure period of the unit } \\
\text { may be appropriate if the unit is an engineered structure; does not } \\
\text { receive or contain liquid waste or waste containing free liquid; is } \\
\text { designed and operated to exclude liquid, precipitation, and other } \\
\text { runon and runoff; has both an inner and outer containment layer with } \\
\text { a leak detection system; is maintained to disallow migration beyond } \\
\text { the outer containment layer before the post-closure care period; and } \\
\text { monitoring results do not identify a statistically significant increase in } \\
\text { hazardous constituents in the upper aquifer during the operational life } \\
\text { of the impoundment. Where multiple regulated units are present at a } \\
\text { facility, the point of compliance for this monitoring can be taken as } \\
\text { the circumscription of all of these units. The concentration of a } \\
\text { hazardous constituent in the uppermost aquifer beneath a regulated } \\
\text { unit is not to exceed the existing background concentration or the } \\
\text { maximum concentration listed in the following table if higher than the } \\
\text { background level, or an alternate concentration limit, unless an } \\
\text { exemption is granted. }\end{array}$ & Not an ARAR & $\begin{array}{l}\text { These requirements are not applicable } \\
\text { to the proposed action because a } \\
\text { disposal site is outside the scope of the } \\
\text { proposed action, even if site waste } \\
\text { meets the prerequisites for definition as } \\
\text { characteristic hazardous waste. Further, } \\
\text { the maximum concentrations for } \\
\text { groundwater is not relevant and } \\
\text { appropriate because groundwater } \\
\text { remediation is outside the scope of the } \\
\text { proposed removal action. }\end{array}$ \\
\hline
\end{tabular}


TABLE A.3 (Cont'd)

\begin{tabular}{|c|c|c|c|c|c|c|}
\hline Potential ARAR & Action & & Requ & & $\begin{array}{l}\text { Preliminary } \\
\text { Determination }\end{array}$ & Remarks \\
\hline \multirow[t]{19}{*}{ (Cont'd) } & & Constituent & Unit & Concentration & & \\
\hline & & Metals: & & & & \\
\hline & & Arsenic & $\mu \mathrm{g} / \mathrm{L}$ & 50 & & \\
\hline & & Barium & $\mu \mathrm{g} / \mathrm{L}$ & 1,000 & & \\
\hline & & Cadmium & $\mu g / L$ & 10 & & \\
\hline & & Chromium & $\mu \mathrm{g} / \mathrm{L}$ & 50 & & \\
\hline & & Lead & $\mu g / L$ & 50 & & \\
\hline & & Mercury & $\mu g / L$ & 2 & & \\
\hline & & Selenium & $\mu \mathrm{g} / \mathrm{L}$ & 10 & & \\
\hline & & Silver & $\mu g / L$ & 50 & & \\
\hline & & Organic & & & & \\
\hline & & Compounds: & & & & \\
\hline & & Endrin & $\mu g / L$ & 0.2 & & \\
\hline & & Lindane & $\mu \mathrm{g} / \mathrm{L}$ & 4 & & \\
\hline & & Methoxychlor & $\mu \mathrm{g} / \mathrm{L}$ & 100 & & \\
\hline & & Toxaphene & $\mathrm{\mu g} / \mathrm{L}$ & 5 & & \\
\hline & & $2,4-D^{2}$ & $\mu g / L$ & 100 & & \\
\hline & & 2,4,5-TP Silvex & $\mu g / L$ & 10 & & \\
\hline & & \multicolumn{4}{|c|}{ a 2,4 -Dichlorophenoxyacetic acid } & \\
\hline $\begin{array}{l}\text { Solid Waste Disposal Act, as } \\
\text { amended ( } 42 \text { USC } 6901 \text {, et seq.); } \\
\text { Solid Wastes ( } 40 \text { CFR 264), } \\
\text { Subpart I, Use and Management } \\
\text { of Containers }\end{array}$ & Waste storage & \multicolumn{3}{|c|}{$\begin{array}{l}\text { Containers used to store hazardous waste must be dosed and in good } \\
\text { condition. }\end{array}$} & $\begin{array}{l}\text { Potentially } \\
\text { applicable }\end{array}$ & $\begin{array}{l}\text { These requirements may be applicable } \\
\text { to the proposed action, container } \\
\text { storage, and transportation of site waste } \\
\text { that meets the prerequisites for } \\
\text { definition as characteristic hazardous } \\
\text { waste. }\end{array}$ \\
\hline $\begin{array}{l}\text { Solid Waste Disposal Act, as } \\
\text { amended (42 USC } 6901 \text {, et seq.); }\end{array}$ & \multirow[t]{4}{*}{ Waste disposal } & \multirow{4}{*}{\multicolumn{3}{|c|}{$\begin{array}{l}\text { The land disposal of certain hazardous waste (e.g., contaminated soil } \\
\text { and debris) without proper treatment is restricted, unless a treatability } \\
\text { variance is appropriate. Such treatment must attain levels achievable } \\
\text { by the best demonstrated available technologies (BDAT) for each } \\
\text { hazardous constituent in the listed waste. }\end{array}$}} & \multirow[t]{4}{*}{ Not an ARAR } & \multirow{4}{*}{$\begin{array}{l}\text { These requirements are not applicable } \\
\text { because there will be no land disposal } \\
\text { of contaminanted soil or debris from } \\
\text { other sites to the Elza Gate site, nor any } \\
\text { consolidation of site wastes into a new } \\
\text { disposal or storage area which would } \\
\text { trigger RCRA land disposal } \\
\text { requirements. }\end{array}$} \\
\hline Land Disposal Restrictions & & & & & & \\
\hline (40 CFR 268), Subpart C, & & & & & & \\
\hline Prohibition on Land Disposal & & & & & & \\
\hline
\end{tabular}




\section{TABLE A.3 (Cont'd)}

\begin{tabular}{|c|c|c|c|c|}
\hline Potential ARAR & Action & Requirement & $\begin{array}{c}\text { Preliminary } \\
\text { Determination }\end{array}$ & Remarks \\
\hline $\begin{array}{l}\text { Tennessee Hazardous Waste } \\
\text { Management Rules, Ternessee } \\
\text { Department of Public Helath } \\
\text { Rules, Chapter } 1200-1-11\end{array}$ & Waste disposal & $\begin{array}{l}\text { These regulations set forth general requirements for identification and } \\
\text { listing of hazardous waste, standards for owners and operators of } \\
\text { hazardous waste treatment, storage and disposal facilities, including } \\
\text { maximum concentrations of constituents for groundwater protection } \\
\text { at disposal facilities. }\end{array}$ & Not an ARAR & $\begin{array}{l}\text { These requirements are not applicable } \\
\text { to the proposed action because a } \\
\text { disposal site is outside the scope of the } \\
\text { proposed action, even if site waste } \\
\text { meets the prerequisites for definition as } \\
\text { characteristic hazardous waste. Further, } \\
\text { the maximum concentrations for } \\
\text { groundwater is not relevant and } \\
\text { appropriate because groundwater } \\
\text { remediation is outside the scope of the } \\
\text { proposed removal action. These } \\
\text { requirements are not applicable because } \\
\text { there will be no land disposal of } \\
\text { contaminanted soil or debris from other } \\
\text { sites to the Elza Gate site, nor any } \\
\text { consolidation of site wastes into a new } \\
\text { disposal or storage area which would } \\
\text { trigger RCRA land disposal } \\
\text { requirements. }\end{array}$ \\
\hline $\begin{array}{l}\text { Tennessee Hazardous Waste } \\
\text { Management Rules, Tennessee } \\
\text { Department of Public Helath } \\
\text { Rules, Chapter 1200-1-11.03 and } \\
\text { 1200-1-11.04 }\end{array}$ & $\begin{array}{l}\text { Waste } \\
\text { generation and } \\
\text { transportation }\end{array}$ & $\begin{array}{l}\text { General requirements for packaging, labeling, and marking hazardous } \\
\text { wastes for temporary storage and transportation. }\end{array}$ & $\begin{array}{l}\text { Potentially } \\
\text { applicable }\end{array}$ & $\begin{array}{l}\text { These requirements would be applicable } \\
\text { to the proposed removal action if any } \\
\text { site waste meets the prerequisites for } \\
\text { definition as characteristic or listed } \\
\text { hazardous waste under Chapter 1200-1- } \\
11-02 \text {. }\end{array}$ \\
\hline
\end{tabular}

Teneration and

General requirements for packaging, labeling, and marking hazardous

Potentially

applicable 